\title{
Jurisdictional Competition for Trust Funds: An Empirical Analysis of Perpetuities and Taxes
}

\section{Citation}

Robert H. Sitkoff \& Max Schanzenbach, Jurisdictional Competition for Trust Funds: An Empirical Analysis of Perpetuities and Taxes, 115 Yale L.J. 356 (2005).

\section{Published Version}

http://www.yalelawjournal.org/article/jurisdictional-competition-for-trust-funds-an-empiricalanalysis-of-perpetuities-and-taxes

\section{Permanent link}

http://nrs.harvard.edu/urn-3:HUL.InstRepos:15034751

\section{Terms of Use}

This article was downloaded from Harvard University's DASH repository, and is made available under the terms and conditions applicable to Other Posted Material, as set forth at http:// nrs.harvard.edu/urn-3:HUL.InstRepos:dash.current.terms-of-use\#LAA

\section{Share Your Story}

The Harvard community has made this article openly available.

Please share how this access benefits you. Submit a story.

Accessibility 


\title{
Northwestern University School of Law \\ Law and Economics Papers
}

Year 2005

Paper 14

\section{Jurisdictional Competition for Trust Funds: An Empirical Analysis of Perpetuities and Taxes}

\author{
Robert H. Sitkoff*
}

\author{
Max Matthew Schanzenbach ${ }^{\dagger}$
}

*Northwestern University School of Law, rsitkoff@law.harvard.edu

${ }^{\dagger}$ Northwestern University School of Law, m-schanzenbach@law.northwestern.edu

This working paper is hosted by The Berkeley Electronic Press (bepress) and may not be commercially reproduced without the permission of the copyright holder.

http://law.bepress.com/nwwps-lep/art14

Copyright (C) 2005 by the authors. 


\title{
Jurisdictional Competition for Trust Funds: An Empirical Analysis of Perpetuities and Taxes
}

\author{
Robert H. Sitkoff and Max Matthew Schanzenbach
}

\begin{abstract}
This paper presents the results of the first empirical study of the domestic jurisdictional competition for trust funds. In order to open a loophole in the federal estate tax, a rash of states have abolished the Rule Against Perpetuities. Based on reports to federal banking authorities, we find that through 2003 a state's abolition of the Rule increased its trust assets by $\$ 6$ billion (a 20 percent increase on average) and increased its average trust account size by $\$ 200,000$. These estimates imply that roughly $\$ 100$ billion in trust funds have moved to take advantage of the abolition of the Rule. Interestingly, states that levied an income tax on trust funds attracted from out of state experienced no increase in trust business after abolishing the Rule. This is a striking finding for the theory of jurisdictional competition, because it implies that abolishing the Rule does not directly increase a state's tax revenue. Yet the jurisdictional competition for trust funds is patently real and profound. Our findings also speak to unresolved issues of policy concerning state property law and federal tax law.
\end{abstract}


Essay

Jurisdictional Competition for Trust Funds:

\title{
An Empirical Analysis of Perpetuities and Taxes
}

\section{Robert H. Sitkoff* and Max Schanzenbach ${ }^{* *}$}

\begin{abstract}
This Essay presents the results of the first empirical study of the domestic jurisdictional competition for trust funds. Since 1986, a third of the states have abolished the Rule Against Perpetuities to open a loophole in the federal estate tax. Since 1997, a handful of states have validated self-settled asset protection trusts, which allow the settler to shield assets from creditors. Based on reports to federal
\end{abstract}

\footnotetext{
* Visiting Professor of Law, New York University; Associate Professor of Law, Northwestern University.

** Assistant Professor of Law, Northwestern University. The authors thank Mark Ascher, Ronen Avraham, Richard Brooks, Jon Corsico, Charlotte Crane, Robert Daines, Joel Dobris, Richard Epstein, Howard Helsinger, David Hodgman, Marcel Kahan, John Langbein, James Lindgren, Bruce Mann, John Morley, Richard Nenno, Jeffrey Pennell, Richard Posner, Larry Ribstein, Jeffrey Schoenblum, Rachel Silverman, Samuel Sitkoff, Stewart Sterk, Jeff Strnad, Joshua Tate, Lawrence Waggoner, Albert Yoon, and workshop participants at Northwestern, Stanford, U.C. Davis, and at annual meetings of the American, Canadian, and Midwest Law and Economics Associations for helpful comments and suggestions; Anthony DiMilo of the FDIC for invaluable assistance in understanding the data; Georgia Alexakis, Lisa Chessare, Ben Frey, and Jammey Kligis for superb research assistance; Pageen Bassett and Kathryn Hensiak for additional research support; the Searle Fund for Policy Research and the Victor Family Research Fund for financial support; and Tamara Scheinfeld Sitkoff and Diane Whitmore Schanzenbach for their patience.
} 
banking authorities, we find that through 2003 a state's abolition of the Rule increased its reported trust assets by $\$ 6$ billion (a 20\% increase on average) and increased its average trust account size by $\$ 200,000$. By contrast, our examination of self-settled asset protection trusts yielded indeterminate results. Our perpetuities findings imply that roughly $\$ 100$ billion in trust funds have moved to take advantage of the abolition of the Rule. Interestingly, states that levied an income tax on trust funds attracted from out of state experienced no increase in trust business after abolishing the Rule. This finding has relevance for the study of jurisdictional competition, because it implies that abolishing the Rule does not directly increase a state's tax revenue. Yet the jurisdictional competition for trust funds is patently real and profound. Our findings also speak to unresolved issues of policy concerning state property law and federal tax law.

\section{INTRODUCTION}

By year end 2004, twenty states had validated perpetual trusts by abolishing the centuries-old Rule Against Perpetuities (the Rule or the RAP) as applied to interests in trust. The driving force for this abrupt turnabout was not a careful reconsideration of the ancient common law policy against perpetuities, but rather a 1986 reform to the federal tax code. Under the 1986 code (as amended through 2005 ), a transferor can pass $\$ 1$ million during life, or $\$ 1.5$ million at death, free of federal wealth transfer taxes. ${ }^{1}$ By placing this $\$ 1$ million or $\$ 1.5$ million in a trust, successive generations can benefit from the trust fund, free from federal wealth transfer taxes, for as long as state perpetuities law will allow the trust to endure. In a state that has abolished the Rule, successive generations can benefit from the trust fund, free of subsequent federal wealth transfer taxation, forever.

This Essay presents the results of the first empirical study of the jurisdictional competition for trust funds. Based on state-level panel data assembled from annual reports to federal banking authorities by institutional trustees, we find that the interstate competition for trust

1. Federal wealth transfer taxes comprise estate, gift, and generation-skipping transfer (GST) taxes. For an accessible introduction, see STEPHANIE J. WILLBANKS, FEDERAL ESTATE AND GIFT TAXATION: AN ANALYSIS AND CRITIQUE (3d ed. 2004). 
funds is both real and profound. Our analysis indicates that through 2003, a state's abolition of the Rule Against Perpetuities increased its reported trust assets by about $\$ 6$ billion and its average trust account size by roughly $\$ 200,000$. To put these figures in perspective, in 2003 the average state had roughly $\$ 19$ billion in reported trust assets and an average account size of about $\$ 1$ million. In the timeframe of our data, sixteen states abolished the Rule, implying that through 2003 roughly $\$ 100$ billion in trust assets have moved as a result of the Rule's abolition. ${ }^{2}$ This figure represents about $10 \%$ of the total trust assets reported to federal banking authorities in 2003.

Prior to our study, the evidence of jurisdictional competition in trust law was anecdotal. Lawyers and bankers in New York and other states that have not abolished the Rule regularly complain about the loss of billions of dollars in trust business to South Dakota, Delaware, and other trust-friendly jurisdictions. ${ }^{3}$ The practitioner journals on estate planning are rife with assessments of the different state laws and advertisements by banks and trust companies touting the virtues of one state or another. ${ }^{4}$ Anecdotes of competition have even been reported by popular media outlets such as the Wall Street Journal, New York Times, and Forbes Magazine. ${ }^{5}$

In spite of this anecdotal evidence, before our study there were at least two reasons to be dubious about the magnitude of the jurisdictional competition for trust funds. First, no state collects a filing or other fee on the creation of a private trust under its law, and several

2. The $\$ 100$ billion figure is only a point estimate. For discussion of this estimate and its confidence interval, see infra note 125 and accompanying text.

3. See, e.g., Charles F. Gibbs \& Colleen Carew, Trusts Leaving New York, Situs in Cyberspace: Time for Legislation?, N.Y.L.J., Dec. 20, 2002, at 3 ("Our New York state trust banker friends have been proclaiming for some years now a substantial loss of trust business to Delaware, South Dakota, and other more-hospitable venues."); Thomas Scheffey, Is Immortality Just Around The Corner? "Dead Hand" Trust Law Relaxes Its Grip, CONN. L. TRIB., Mar. 4, 2002, at 10 (noting that Connecticut lawyers and bankers were lobbying for repeal of the Rule); Charles F. Gibbs \& Marilyn Ordover, An Open Letter to Assemblywoman Ann Carrozza, N.Y.L.J., Feb. 5, 2001, at 3 (arguing that "to remain competitive with the other states," New York must repeal the RAP).

4. See, e.g., Jesse DUKEMINIER, STANLEY M. JohANSOn, JAMES LindGREN \& RoBERT H. SITKOFF, WILls, TRUSTS, AND EstATES 714 (7th ed. 2005) (reproducing a Wells Fargo ad touting South Dakota as a "place where there is no rule against perpetuities" and "no fiduciary income tax"); Daniel G. Worthington, The Problems and Promise of Perpetual Trusts Laws, TR. \& EsT., Dec. 2004, at 15.

5. See Carole Gould, Shifting Rules Add Luster to Trusts, N.Y. TIMES, Oct. 29, 2000, § 3; Rachel Emma Silverman, States Toss Out Restrictions on Creating Perpetual Trusts; Downside-Fees Lost Forever, Too, WALL ST. J., Sept. 15, 2004, at D1; John Turrettini, Providing for the Year 3000, FORBES, June 11, 2001, at 220. In February 2005, the Wall Street Journal published an article summarizing our findings as reported in an earlier draft. Rachel Emma Silverman, Looser Trust Laws Lure \$100 Billion, Wall St. J., Feb. 16, 2005, at D1; see also Bruce W. Fraser, The Rush To Dynasty Trusts, FIN. ADV., June 2005, at 111 (same). 
of the leading jurisdictions that have abolished the Rule do not levy income taxes on trust funds attracted from out of state. ${ }^{6}$ Hence, in these states there is no direct state revenue payoff from attracting trust funds.

Second, the main tax benefits of a trust not subject to the Rule Against Perpetuities accrue not to the donor, but to beneficiaries whose interest in the trust will not vest within twenty-one years of the death of a life in being at the time the trust became irrevocable. Hence, as compared to an ordinary in-state trust, the added benefits of settling an out-of-state perpetual trust flow to beneficiaries who are remote descendants unknown to the donor. ${ }^{7}$

Accordingly, the absence of empirical study of the jurisdictional competition for trust funds represents a gaping hole in the literature. This lacuna stems from the difficulties that inhere in such a project. First, because inter vivos trusts are private arrangements for which there are no public filings, it is commonly assumed that data is unavailable. For example, Jesse Dukeminier and James Krier, authors of a widely-used casebook on property law, believe that "[i]t is difficult to get hard data on the popularity of perpetual trusts among consumers." ${ }^{8}$ Likewise, Eric Rakowski has written that "[t]here is no way to count [perpetual trusts] with certainty." In a similar vein, the English Law Commission, which in the 1990s was tasked to make recommendations on perpetuities reform in England, "considered the possibility of commissioning a full study of the economic implications of abolishing the rule," but declined to do so "because it proved impossible to obtain sufficient data."10

Second, the domestic perpetual-trust phenomenon exists at the intersection of several varied and complex bodies of law including the

6. More precisely, these states do not levy a tax on income in a trust consisting of stocks, bonds, and other financial assets if the trust was settled by a nonresident for the benefit of nonresidents even if an in-state bank or trust company serves as trustee and the trust provides that it is to be governed by the law of that state. See infra Subsection II.D.2.

7. For example, suppose that the donor's grandchild is living at the time the trust becomes irrevocable. That grandchild is a measuring life validating a remainder in that grandchild's unborn children, who would be the transferor's greatgrandchildren. In such a scenario, assuming the trust is for that particular grandchild's branch of the family only, the first generation for which abolition of the Rule makes a difference is that of the donor's great-great-grandchildren, who share only a $6.25 \%$ genetic overlap with the donor. We thank Lawrence Waggoner for suggesting the genetic calculation.

8. Jesse Dukeminier \& James E. Krier, The Rise of the Perpetual Trust, 50 UCLA L. REV. 1303, 1315 (2003).

9. Eric Rakowski, The Future Reach of the Disembodied Will, 4 POL. PHIL. \& ECON. 91, 124 n.8 (2005).

10. ENG. LAw COMM’N, RePORT No. 251, The Rules Against PERPETUITIES AND EXCESSIVE ACCUMULATIONS 20 (1998). 
Rule Against Perpetuities, federal wealth transfer taxes, and state fiduciary income taxes. Designing an empirical study of the perpetualtrust phenomenon thus requires sensitivity to each of those fields. Moreover, to avoid omitting other potentially relevant variables, empirical study of the perpetual-trust phenomenon also requires accounting for other possible margins of jurisdictional competition for trust funds. Perhaps the most significant is the rise of the self-settled asset protection trust (APT). Contrary to traditional law, in a jurisdiction that has validated APTs, the settlor can shield assets from creditors by placing them in a trust for his or her own benefit.

Our findings provide strong evidence of a national market for trust funds that is responsive to the interplay between state trust law and federal tax law. Contrary to the standard theoretical and practical accounts of jurisdictional competition, which view increased state tax revenue as the incentive for states to compete, ${ }^{11}$ we find that the only states that experienced an increase in trust business after abolishing the Rule were those that did not levy an income tax on trust funds attracted from out of state. Although in tension with the dominant model of jurisdictional competition, this finding is strongly intuitive. The demand for perpetual trusts stems largely from their utility in avoiding federal wealth transfer taxes. ${ }^{12}$ Donors who are who are sensitive to the federal transfer taxes are likely also to be sensitive to state income taxes.

Our findings have broad implications for both policy and theory. Regarding policy, we find strong evidence that transferors have been escaping the Rule's application at an increasingly rapid pace since the mid-1990s.. Although neither the federal wealth transfer taxes nor the interstate competition for trust funds bear on the policies underpinning the Rule, together they have mortally wounded the Rule by reducing it to a mere transaction cost. Accordingly, to the extent that the policies underpinning the Rule continue to have contemporary relevance, it is necessary to look elsewhere to service those policies.

Our results are also relevant to the ongoing policy debate over the future of federal wealth transfer taxation, now before Congress. ${ }^{13} \mathrm{~A}$

11. See, e.g., Roberta Romano, THE GeniUs of AMERICAN CORPORATE LAW 6-16 (1993); William W. Bratton \& Joseph A. McCahery, The New Economics of Jurisdictional Competition: Devolutionary Federalism in a Second-Best World, 86 GEO. L.J. 201, 235-39 (1987); Dennis Epple \& Allan Zelenitz, The Implications of Competition Among Jurisdictions: Does Tiebout Need Politics?, 89 J. POL. ECON. 1197, 1204-10 (1981); Daryl J. Levinson, Empire-Building Government in Constitutional Law, 118 HARV. L. REV. 915, 945-949 (2005).

12. See Max Schanzenbach \& Robert H. Sitkoff, Perpetuities or Taxes: Explaining the Rise of the Perpetual Trust, 27 CARDOZO L. REV. 2006). (forthcoming

13. See Joint Comm. on Taxation, Options to Improve Tax Complance 
principal tax policy underlying the 1986 code, the relevant features of which remain in effect today, is to prevent the "enjoyment of property followed by its movement down the generations without being subjected to estate or gift tax." into practice, it will need to close the loophole opened by the states that have abolished the Rule Against Perpetuities. Successful implementation of federal tax policy necessarily requires attention to its interaction with state property law. It is thus worth noting that, in a recent report, the staff of the Joint Committee on Taxation proposed closing the perpetuities loophole - but its analysis is based in part on an empirical assumption that we show to be erroneous. ${ }^{15}$

On a theoretical level, our findings are relevant to the ongoing scholarly debate over the nature of jurisdictional competition. Our findings not only contradict the simple, state revenue-based model, but they also cast doubt on recent high-profile work that, by showing a lack of tax revenue from attracting new business, questions the existence of the phenomenon. ${ }^{16}$ Instead, our findings lend support to an interest-group model, one that is rooted in public choice theory. ${ }^{17}$ Even if attracting business does not have an immediate impact on the state's tax revenue, local interest groups may nonetheless benefit from, and hence lobby for, laws that will attract business to the state.

The rest of the Essay is organized as follows. Part I motivates the empirical analysis and explains the relevant legal issues: the race to abolish the Rule Against Perpetuities, the pertinent features of the federal wealth transfer tax system, the state taxation of trust income, and the controversial recognition of self-settled asset protection trusts. Part II describes the dataset and briefly addresses its limitations. Part III presents the empirical analysis, which proceeds in three steps. First, we present an initial analysis of the raw data. In some key states, the effect of abolishing the Rule is readily apparent and simple

AND REFORM TAX EXPENDITURES 392-424 (Jan. 27, 2005), available at http://www.house.gov/jct/s-2-05.pdf; infra note 172 and accompanying text.

14. JeFFrey N. PENNELl, WEALTH TRANSFER PlanNING AND DRAFTING 18-27 (2005); see also H.R. REP. No. 99-426, at 824-25 (1985); JOINT COMM. ON TAXATION, supra note 13, at 394; WILLBANKS, supra note $1, \S 15.07$.

15. See JoInT COMM. ON TAXATION, supra note 13, at 392-95. This report is discussed in the text accompanying notes 174-175.

16. See Lucian Arye Bebchuk \& Assaf Hamdani, Vigorous Race or Leisurely Walk: Reconsidering the Competition over Corporate Charters, 112 YALE L.J. 553 (2002); Marcel Kahan \& Ehud Kamar, The Myth of State Competition in Corporate Law, 55 STAN. L. REV. 679 (2002).

17. See, e.g., William J. Carney, The Political Economy of Competition for Corporate Charters, 26 J. LEGAL STUD. 303 (1997); Jonathan R. Macey \& Geoffrey P. Miller, Toward an Interest-Group Theory of Delaware Corporate Law, 65 TEX. L. REV. 469 (1987); Robert H. Sitkoff, Corporate Political Speech, Political Extortion, and the Competition for Corporate Charters, 69 U. CHI. L. REV. 1103, 1143-49 (2002). 
graphical depictions are highly suggestive. Second, we present a more formal econometric analysis that employs a standard differencein-difference regression methodology that controls for contemporaneous changes in state law and relevant economic factors. Third, we offer a nontechnical summary of our principal findings. Part IV assesses the implications of our findings for the various policy and scholarly debates identified above. After a short conclusion, the tables summarizing our regression results (Tables 1-4), our dating of trust law changes (Table 5), and two substantive appendices follow.

\section{JURISDICTIONAL COMPETITION FOR TRUST FUNDS}

In this Essay we examine the effect of abolishing the Rule Against Perpetuities on a state's trust business. To do so, however, we must also account for other state trust and tax laws that might impact a donor's choice of jurisdiction. Accordingly, in this Part we review: (1) the Rule Against Perpetuities; (2) the relevance of the Rule for minimizing federal estate, gift, and generation-skipping transfer taxes (collectively, the federal wealth transfer taxes); (3) the controversial authorization of self-settled asset-protection trusts; and (4) the state income taxation of trust funds attracted from out of state.

\section{A. The Rule Against Perpetuities ${ }^{18}$}

Few rules of property law are as storied as the Rule Against Perpetuities. The classic formulation is that of John Chipman Gray: "No interest is good unless it must vest, if at all, not later than twenty-one years after some life in being at the creation of the interest." 19 The period of the Rule reflects a common law policy that a transferor should be allowed to tie up property for only so long as the life of anyone possibly known to the transferor plus the next generation's minority (hence lives in being plus 21 years). ${ }^{20}$

18. Portions of this section draw on DUKEMINIER ET AL., supra note 4, at 67477, 686, 695-99.

19. John Chipman Gray, The Rule Against Perpetuities $\S 201$, at 191 (4th ed. 1942).

20. See 6 AMERICAN LAW OF PROPERTY $\$ 24.16$, at 51 (A. James Casner ed., 1952) (noting that the Rule permits "a man of property ... [ [to] provide for all of those in his family whom he personally knew and the first generation after them upon attaining majority"). As Hobhouse put it:

A clear, obvious, natural line is drawn for us between those persons and events which the Settlor knows and sees, and those which he cannot know and see. Within the former province we may push his natural affections and his capacity of judgment to make better dispositions than any external Law is likely to make for him. Within the latter, natural affection does not extend, and the wisest judgment is constantly baffled by the course of events. 
The Rule is said to have two purposes: (1) to keep property marketable, and (2) to limit "dead hand" control. Preventing indefinite fracturing of property ownership implements the first policy. The idea is that ownership of land periodically will be reconstituted into fee simple because all contingent future interests in the property must vest or fail within the perpetuities period.

The dead-hand rationale for the Rule is best understood in light of the disagreeable consequences that can arise from unanticipated circumstances. $^{21}$ The Rule implements this anti-dead-hand policy by curbing future interests that, after some period of time and change in circumstances, tie up the property in potentially disadvantageous arrangements. As Brian Simpson explains, "given that one can, to a limited extent only, foresee the future and the problems it will generate, landowners should not be allowed to tie up lands for periods outside the range of reasonable foresight." 22 Forever is a long time.

Measured against these two purposes, the Rule is both under- and overinclusive. The Rule is underinclusive because it only applies to contingent interests, but vested interests can also compromise the Rule's underlying policy objectives. ${ }^{23}$ It is overinclusive because if the trustee is given the power to sell the trust property and reinvest the proceeds, as is typical, ${ }^{24}$ there is no concern with marketability. ${ }^{25}$ Nonetheless, the prevailing academic view is that the Rule "does, by and large, effectively prevent tying up property for an inordinate length of time." 26

Under the orthodox Rule's possibilities test, even the most implausible assumption about what might happen will render a contingent future interest invalid. Hence the casebooks are replete with improbable

Arthur Hobhouse, The DeAd Hand 188, 183-185 (photo. reprint (1880)).

21. Compare T.P. Gallanis, The Rule Against Perpetuities and the Law Commission's Flawed Philosophy, 59 CAMBRIDGE L.J. 284 (2000), with ENGLISH LAW COMM'N, supra note 10, at 5, 8, 20, and LEWIS M. SimES, PUBLIC POLICY AND THE DEAD HAND 58-59 (1955).

22. A.W.B. Simpson, Legal TheOry AND LegAl History 159-60 (1987). Simpson continues: "The good patriarch looks into the future, but not too long. . . . The compromise which English law adopted was to allow property to be tied up for the lifetime of someone in existence at the time of the settlement and a reasonable period thereafter-for example, a minority." Id.

23. The clearest example is a vested interest that will "take ages to become possessory." T.P. Gallanis, The Future of Future Interests, 60 WASH. \& LEE. L. REV. 513, 559-60 (2003).

24. The modern trustee's default powers are broad. See UNIFORM TRUST CODE $\S \S 815-16$ (2000); RESTATEMENT (THIRD) OF TRUSTS $\S 85$ (T.D. No. 4, 2005); DUKEMINIER ET AL., supra note 4, at 777-78; John H. Langbein, The Contractarian Basis of the Law of Trusts, 105 YALE L.J. 625, 640-43 (1995).

25. See SIMES, supra note 22, at 40-42. Although the Rule began as a device to curb tying up land, it was eventually extended to personal property. Today, because almost all life estates and future interests are created in trust rather than as legal interests, the Rule's primary modern application is to interests in trusts funded with stocks, bonds, and other liquid financial assets.

26. DUKEMINIER ET AL., supra note 4, at 675. 
scenarios involving bizarre occurances such as childbearing octogenarians and toddlers, unborn widows, inexhaustible gravel pits, wars that never end, slothful executors, and explosive birthday presents. ${ }^{27}$ The unborn widow scenario is illustrative. Thus:

Case 1. "The Unborn Widow." $T$ bequeaths a fund in trust to $H$ for life, then to H's widow for life, then the remainder to $H$ 's surviving descendants. Even if $H$ is married to $W 1$ at $T$ 's death, the marriage might end and then $H$ could marry $W 2$, who might not have been born before T's death. In such a case, the remainder to $H$ 's descendants will not vest until the death of W2, which could happen more than twenty-one years after the death of all lives in being at the time of T's death.

Such cases, plus the many booby traps that lie hidden in the Rule's intricacies, brought the common law Rule - but not its underlying policy against remote vesting - into disrepute.

Begininng in the 1950s, dissatisfaction with the Rule's exasperating complexities and absurd assumptions led to reform to stay what Barton Leach famously called "the slaughter of the innocents" in the Rule's "reign of terror." 28 Some states enacted statutory fixes for specific fantasy scenarios, in particular the unborn widow and the fertile octogenarian. Other states authorized the courts to reform instruments that otherwise would have been void $a b$ initio. Still other states adopted the so-called wait-and-see principle whereby courts wait to see if, in light of actual instead of possible events, the interest will in fact vest or fail within a specified period. The culmination of this reform movement was the 1986 Uniform Statutory Rule Against Perpetuities (USRAP). USRAP, some form of which is now in force in about half the states, provides a wait-and-see period of ninety years and authorizes reformation of instruments that would otherwise violate the Rule.

These reforms were not without controversy. On the contrary, the

27. See Elias Clark et al., Gratuitous Transfers 753-69; Joel C. Dobris ET AL., ESTATES AND TRUSTS 839-48 (2d ed. 2003); DUKEMINIER ET AL., supra note 4, at 678-86; JESSE DUKEMINIER \& JAMES E. KRIER, PROPERTY 306-11 (5th ed. 2002); William M. McGovern, JR. \& Sheldon F. Kurtz, Wills, Trusts AND Estates 457 (3d ed. 2004); Eugene SCOlES ET AL., DeCEDENT'S EsTATES AND TRUSTS 1075-78 (6th ed. 2000); JOSEPH William SingER, PROPERTY LAW 608-09 (3d ed. 2002); VALERIE J. VOLLMAR ET AL., AN INTRODUCTION TO TRUSTS AND ESTATES 982-85 (2003); LAWrence W. WAGgONER ET Al., FAMILy Property LaW 1206-18 (3d ed. 2002.

28. See W. Barton Leach, Perpetuities in Perspective: Ending the Rule's Reign of Terror, 65 HARV. L. REV. 721 (1952); W. Barton Leach, Perpetuities: Staying the Slaughter of the Innocents, 68 L.Q. REV. 35 (1952). 
debate "came to resemble a holy war." 29 Leach's advocacy of waitand-see in the 1950s prompted a wave of forceful opposition led by Michigan's Lewis Simes. ${ }^{30}$ When Leach's Harvard colleague James Casner proposed writing wait-and-see into the Restatement (Second) of Property in the late 1970s, Professor Richard Powell, then almost ninety, came out of retirement to join with his Columbia colleagues Curtis Berger and Louis Lusky to speak against doing so. In 1986, with the promulgation of USRAP, still another epic battle broke out, this time between UCLA's Jesse Dukeminier and Michigan's Lawrence Waggoner, USRAP's principal drafter. ${ }^{31}$

Both the existence and the ferociousness of those debates have relevance to the present study for two reasons. First, they bring into sharp relief the abruptness of abolishing the Rule altogether. The prior debates focused on reforming the Rule, not abandoning it. Abolition represents a stark departure from a longstanding principle of Anglo-American common law. Yet there has been little or no debate on the merits of the Rule in the state legislatures that have abolished it. ${ }^{32}$ By documenting the impact of abolishing the Rule, we hope that

29. Dukeminier \& Krier, supra note 8, at 1306; see also Susan F. French, Perpetuities: Three Essays in Honor of My Father, 65 WASH. L. REV. 323, 332-34 (1990) (describing the "Perpetuities Wars").

30. See Lewis M. Simes, Is the Rule Against Perpetuities Doomed? The "Wait and See” Doctrine, 52 MICH. L. REV. 179, 184-190 (1953). Leach responded to Simes and other critics of wait-and-see in W. Barton Leach, Perpetuities Legislation: Hail, Pennsylvania!, 108 U. PA. L. REV. 1124 (1960). For a comprehensive bibliography on perpetuities reform, see 10 POWELL ON REAL PROPERTY § 75A.07 (Michael Allan Wolf ed., 2000). There exists no precise count of the trees sacrificed to the perpetuities wars.

31. The Dukeminier/Waggoner debate centered on the mechanics for measuring the wait-and-see period. Waggoner supported USRAP's ninety-year period. Dukeminier favored using lives causally related to vesting and argued that adoption of USRAP's ninety year period would lead eventually to the Rule's demise. See Lawrence W. Waggoner, Perpetuity Reform, 81 MICH. L. REV. 1718 (1983); 85 COLUM. L. REV. 1648, 1648-1747 (1985) (comprising five articles); Jesse Dukeminier, Wait-and-See: The Causal Relationship Principle, 102 L.Q. REV. 250 (1986); Jesse Dukeminier, The Uniform Statutory Rule Against Perpetuities: Ninety Years in Limbo, 34 UCLA L. REV. 1023 (1987) [hereinafter Dukeminier, Limbo]; Lawrence W. Waggoner, The Uniform Statutory Rule Against Perpetuities: The Rationale of the 90-Year Waiting Period, 73 CORNELL L. REV. 157 (1988). For perspectives on USRAP by persons other than Dukeminier and Waggoner, see Ira Mark Bloom, Perpetuities Refinement: There Is an Alternative, 62 WASH. L. REV. 23 (1987); Mary Louise Fellows, Testing Perpetuity Reforms: A Study of Perpetuity Cases 1984-89, 25 REAL Prop. ProB. \& Tr. J. 597 (1991); Amy Morris Hess, Freeing Property Owners from the RAP Trap: Tennessee Adopts the Uniform Statutory Rule Against Perpetuities, 62 TENN. L. REV. 267 (1995); Ronald C. Link \& Kimberly A. Licata, Perpetuities Reform in North Carolina: The Uniform Statutory Rule Against Perpetuities, Nondonative Transfers, and Honorary Trusts, 74 N.C. L. REV. 1783 (1996); see also Paul G. Haskell, A Proposal for a Simple and Socially Effective Rule Against Perpetuities, 66 N.C.L. REV. 545 (1988) (proposing a rule of trust duration of 120 years).

32. Dukeminier and Krier make this point strongly: "[The] absence of interest in perpetual trusts prior to the GST tax gives rise to the troubling likelihood that the 
this Essay will facilitate a reasoned public policy discourse informed by empirical realities.

Second, our analysis may throw light on a significant point of dispute between Waggoner and Dukeminier. Dukeminier argued that lawyers might use USRAP's ninety-year wait-and-see period as a planning device, employing ninety-year trusts instead of designing more tailored trusts using special powers of appointment and the like. ${ }^{33}$ We therefore test whether a state's adoption of USRAP attracted trust assets to the state. This is an imperfect assessment of Dukeminier's prediction, however, because in the period under study perpetual trusts became widely available. Whatever the advantages of a ninety-year trust, a perpetual trust offers more.

Another reason to suppose that a state's enactment of USRAP would not attract trust assets is the prior emergence of the perpetuities saving clause. A saving clause ensures that an overlooked violation of the Rule will not render the trust invalid. ${ }^{34}$ As a result, even in a jurisdiction that has retained the common law Rule, the state of the art in drafting makes it easy to establish a trust that will endure for a century, if not longer, ${ }^{35}$ and inclusion of a perpetuities saving clause

Rule Against Perpetuities is being abolished with little if any reflection upon the merits of the Rule on its own, without regard to tax considerations." Dukeminier \& Krier, supra note 8, at 1317. There is, however, a considerable scholarly literature on the race to abolish the Rule. See, e.g., Ira Mark Bloom, The GST Tax Tail Is Killing the Rule Against Perpetuities, 87 TAX NOTES 569 (2000); Verner F. Chaffin, Georgia's Proposed Dynasty Trust: Giving the Dead Too Much Control, 35 GA. L. REV. 1 (2000); Joel C. Dobris, The Death of the Rule Against Perpetuities, or The RAP Has No Friends-An Essay, 35 REAL Prop. ProB. \& TR. J. 601 (2000); Dukeminier \& Krier, supra note 8; Stephen E. Greer, The Alaska Dynasty Trust, 18 ALASKA L. REV. 253 (2001); Rakowski, supra note 9; Stewart E. Sterk, Jurisdictional Competition to Abolish the Rule Against Perpetuities: R.I.P. for the R.A.P., 24 CARDOZO L. REV. 2097, 2103-04 (2003); Joshua C. Tate, Perpetual Trusts and the Settlor's Intent, 53 U. KAN. L. REV. 595 (2005); Angela M. Vallario, Death by a Thousand Cuts: The Rule Against Perpetuities, 25 J. LEGIS. 141 (1999).

33. See Dukeminier, Limbo, supra note 31, at 1039-41; Jesse Dukeminier, The Uniform Statutory Rule Against Perpetuities and the GST Tax: New Perils for Practitioners and New Opportunities, 30 REAL. Prop. PROB. \& TR. J. 185, 207-09 (1995) [hereinafter Dukeminier, Perils]; Jesse Dukeminier, Dynasty Trusts: Sheltering Descendants From Transfer Taxes, 23 EST. PLAN. 417, 420-21 (1996); JESSE DUKEMINIER \& STANLEY M. JOHANSON, Wills, TRUSTS, AND ESTATES 852 (6th ed. 2000); see also DOBRIS ET AL., supra note 27, at 895 (suggesting that USRAP "is likely to become a planning doctrine").

34. See DUKEMINIER ET AL., supra note 4, at 695-96; WAGGONER ET AL., supra note 27, at 1218-27; DAVID M. BeCKER, PerPetuities AND Estate PlanNING 133-184 (1993).

35. See PENNELL, supra note 14, at 18-26. Although probably not used in practice, see WAGGONER ET AL., supra note 27, at 1222-23, the idea of a "twelve-healthybabies clause" has captured the academic imagination:

[A] settlor, when motivated by vanity, is able to tie up his property, regardless of lives and deaths in his family, for . . . twenty-one years after the deaths of a dozen or so healthy babies chosen from families noted for longevity, a term which, in the ordinary course of events, will add up to about a century. 
is cheaper and easier than going out of state. Indeed, avoiding a perpetuities violation by inclusion of a saving clause is so simple that, contrary to a pernicious leading case, drafting an instrument that violates the Rule is almost certainly malpractice. ${ }^{36}$

Until the recent movement to abolish the Rule Against Perpetuities, the unifying theme of perpetuities reform in the twentieth century was continuing respect for the long-standing policy against remote vesting. Even in its reformed versions and buffered by saving clauses, the Rule requires that contingent interests vest or fail within a specified period. For this reason, prior to its widespread abolition, the Rule continued to represent a practical constraint on trust duration. ${ }^{37}$

\section{B. Federal Wealth Transfer Taxes ${ }^{38}$}

Since the nineteenth century Congress has levied taxes on gratuitous wealth transfers in the form of death and inter vivos gift taxes. Death taxes comprise both estate and inheritance taxes; the two are not synonymous. An estate tax is imposed on the decedent's estate (the transferor). An inheritance tax is imposed on the beneficiaries (the transferees).

Congress first levied an inheritance tax to help fund the Civil War and then again in the 1890 s to fund the war with Spain. ${ }^{39}$ During World War I, Congress turned to an estate tax, which it has continued to levy ever since. Prior to 1986, however, the estate tax could be avoided by using successive life interests. ${ }^{40}$ Because a life tenancy

6 AMERICAN LAW OF PROPERTY $§ 24.16$, at 52 (A. James Casner ed., 1952). The English counterpart is the "royal lives clause," which provides that the trust is to continue until twenty-one years after the death of all the living descendants of Queen Victoria or of some other British monarch. See ENGLISH LAW COMM'N, supra note 10, at 97-98.

36. In Lucas v. Hamm, 364 P.2d 685 (Cal. 1961), the court held that the atypical violation of the Rule at issue in that case did not amount to malpractice. In view of the development of saving clauses, however, Lucas is almost certainly no longer good law. See Wright v. Williams, 121 Cal. Rptr. 194, 199 n.2 (Ct. App. 1975); JoSEPH WILLIAM SINGER, INTRODUCTION TO PROPERTY $\$ 7.7 .4$, at 333 (2d ed. 2005).

37. Becauset the Rule prohibits vesting outside of the applicable perpetuities period, the identity of all persons with a claim to the underlying property will be ascertained within that time. Once all the beneficiaries are ascertained, they can terminate the trust when the perpetuities period expires. The settlor cannot prevent this. RESTATEMENT (SECOND) OF PROPERTY: DONATIVE TRANSFERS $§ 2.1$ (1981); $1 \mathrm{~A}$ Austin WaKeMan SCOTT \& William FranKLIN Fratcher, THE LAW OF TRUSTS $\S 62.10$, at 336 (4th ed. 1987). If the beneficiaries do not terminate the trust, the trust corpus will be distributed to the principal beneficiaries when the preceding life estates expire.

38. Portions of this section draw on DUKEMINIER ET AL., supra note 4, at 84549, 919-22.

39. For an excellent history of federal estate and inheritance taxes, see Louis Eisenstein, The Rise and Decline of the Estate Tax, 11 TAX L. REV. 223 (1956).

40. See Regis W. CAMPfield et AL., TAXATION OF ESTATES, GifTS, AND Trusts 722-24 (22d ed. 2002); JefFrey N. PENNELl, FeDERAL WEALth Transfer 
terminates at death and the estate tax applies only to the decedent's transferable interests, there is no tax on the death of a life tenant. Thus:

Case 2. The Successive Life Estates Loophole. O creates a trust for the benefit of her daughter $A$ for life, and then to $A$ 's daughter $B$ for life ( $O$ 's grandchild), with the remainder to $B$ 's children $(O$ 's greatgrandchildren). Although $O$ may have to pay a gift or estate tax upon the trust's creation, no estate tax will be levied at the death of $A$ or $B$. Not until the death of B's children-O's greatgrandchildren - will another estate tax be due.

Congress sought to close the successive-life-estate loophole with the generation-skipping transfer (GST) tax under the Tax Reform Act of $1986 .{ }^{41}$ In rough terms, a transfer to a grandchild, great-grandchild, or any other person who is two or more generations below the transferor is a generation-skipping transfer; the GST tax is assessed on generation-skipping transfers. ${ }^{42}$ Hence, in Case 2, a GST tax would be payable at the death of $A$ and at the death of $B$. The GST tax rate equals the highest rate of the estate tax, currently $47 \%{ }^{43}$

Under the 1986 Act, however, each transferor has a lifetime exemption from the GST tax, originally $\$ 1$ million and now $\$ 1.5$ million, which is scheduled to grow incrementally to $\$ 3.5$ million by 2009 . ${ }^{44}$ Accordingly, a transferor can fund a trust with the amount of the exemption, free of GST tax, which will endure as long as state perpetuities law permits. Crucially, the federal tax code puts no limit on the duration of the GST tax exemption. Instead, Congress left it to state perpetuities law to limit the duration of a GST-tax-exempt trust. ${ }^{45}$ Thus:

TAXATION 981-83 (4th ed. 2003).

41. The GST tax provisions comprise Chapter 13 of the Internal Revenue Code. I.R.C. $\S \S 2601-2663$ (2000). Congress attempted to close the successive-life-estates loophole in the Tax Reform Act of 1976, but the 1976 scheme was later repealed retroactively. See PENNELL, supra note 40, at 981-88; WILLBANKS, supra note $1, \S$ 15.01 , at 220 .

42. See I.R.C. $\S 2651$ (defining generational assignments); id. § 2613 (defining skip and non-skip persons); id. $\S 2611$ (defining generation-skipping transfer); id. $\S$ 2612 (defining taxable events); see also PAUL R. MCDANIEL ET AL., FEDERAL WEALTH TRANSFER TAXATION 713-16 (5th ed. 2003) (discussing generationskipping transfers); BORIS I. BITTKER ET AL., FEDERAL ESTATE AND GIFT TAXATION 562-67 (9th ed. 2005) (same).

43. The maximum rates are as follows: $49 \%$ in $2003 ; 48 \%$ in $2004 ; 47 \%$ in 2005; 46\% in 2006; and 45\% in 2007-09. I.R.C. $\$ \S 2641,2001$.

44. The exemption schedule is as follows: through 2003, $\$ 1,000,000$; in 2004 and 2005, \$1,500,000; in 2006 through 2008, $\$ 2,000,000$; and in 2009, $\$ 3,500,000$. I.R.C. $\S \S 2631(\mathrm{c}), 2010(\mathrm{c})$.

45. "When Congress originally enacted a tax on generation-skipping transfers, 
Case 3. The GST-Tax-Exempt Trust. $O$ funds a trust with $\$ 1.5$ million that is to pay income to $O$ 's daughter $A$ for life. $A$ is given a special power to appoint the trust corpus [outright or] in further trust to $O$ 's descendants or the spouses of such descendants. ${ }^{46} \mathrm{At}$ $A$ 's death, $A$ exercises her power over the trust corpus by appointing it in her will to her children $B$ and $C$ in equal shares and in further trust, giving each a similar special power over the share of each, and so on. Although $O$ may have had to pay some gift or estate tax upon creating the trust, no estate, gift, or GST tax will be due on the exercise of A's, B's, or C's special power or the exercise of any other subsequent special power for so long as state perpetuities law permits. $^{47}$

Accordingly, in 1986 state perpetuities law became an obviously critical factor in estate planning. The longer the trust in Case 3 could be extended, the more generations could benefit from the trust fund free of transfer taxes.

For at least two reasons the $\$ 1.5$ million (or even $\$ 3.5$ million) figure understates the potential value of this loophole. First, subsequent appreciation in the value of the trust is likewise exempt from transfer taxation for as long as the trust may endure under state perpetuities law. Thus estate planners recommend funding the trust with assets that are likely to experience significant appreciation. ${ }^{48}$ Second, the transfer tax rates are quite high, presently the maximum rate is 47\%. Thus, if the trust were subject to the Rule Against Perpetuities, the fund would be halved at the death of each successive generation at the conclusion of the perpetuities period. ${ }^{49}$

it noted that ' $[\mathrm{m}]$ ost States have a rule against perpetuities which limits the duration of a trust." JOINT COMM. ON TAXATION, supra note 13, at 394.

46. Property subject to a special power, as compared to a general power, is not treated as belonging to the holder of the power for tax purposes. The difference is that the holder of a special power (sometimes also called a limited or non-general power) may not exercise it in favor of the holder's creditors, the holder's estate, or the creditors of the holder's estate. I.R.C. $\S 2041$. Special powers can thus be used to preserve much of the flexibility of ownership without incurring the tax liability of ownership. See DUKEMINIER ET AL., supra note 4, at 596. However, to avoid the risk that the power might be deemed a general power if the beneficiary could appoint the property outright to a minor child, a well-drafted trust would prohibit the beneficiary from using the power to satisfy any obligation to support or educate any person. On the policy significance of the language in brackets, see text accompanyying infra notes 147-148.

47. On the application of the Rule to powers of appointment, see DUKEMINIER ET AL., supra note 4, at 690-95; and WAGGONER ET AL., supra note 27, at 1262-74.

48. See Dukeminier \& Krier, supra note 8, at 1318-19; Pierce H. McDowell, III, Trust Forum Shopping: The Next Generation, TR. \& EsT., Aug. 1997, at 10, 1011 .

49. Although we are dubious of his underlying assumptions, in a recent book 
The foregoing remains the state of the law today, even after the Economic Growth and Tax Relief Reconciliation Act of 2001 (EGTRRA). ${ }^{50}$

\section{The Race to Abolish the RAP}

For reasons unrelated to the GST tax, Idaho, South Dakota, and Wisconsin had already abolished the Rule Against Perpetuities before 1986. But as we show below and in greater detail elsewhere, ${ }^{51}$ these states experienced little to no resulting advantage in the jurisdictional competition for trust funds prior to 1986. Then came the Tax Reform Act of 1986. As the practicing bar digested the Act and grasped the nature of the GST tax, it became apparent that making use of the transferor's exemption in a perpetual trust had significant long-term tax advantages. ${ }^{52}$ If the trust in Case 3, above, were created in Idaho, South Dakota, or Wisconsin, it could continue, free from federal wealth transfer taxation, generation after generation, forever.

As a general matter, prior to 1986 there was little significant variation in trust law across the states. ${ }^{53}$ After the GST tax, however,

Richard Nenno captures the magic of compound growth in the absence of a transfer tax at each generation. Assuming 5\% after-tax growth and a GST tax that would be levied every twenty-five years, a transfer-tax-exempt perpetual dynasty trust funded initially with $\$ 1$ million would be worth $\$ 131,501,258$ after 100 years. This compares with $\$ 10,376,082$ for an initial $\$ 1$ million investment without perpetual transfer-tax-exempt status. See RICHARD W. NENNO, DElawARE DyNASTY TRUSTS, ToTAL RETURN TRUSTS, AND ASSET PROTECTION TRUSTS 176-77 (2005).

50. Pub. L. No. 107-16, 2001 U.S.C.C.A.N. (115 Stat.) 38 (2001). EGTRRA repeals the GST tax and the estate tax (but not the gift tax) as to transfers that take place in 2010. EGTRRA also reduces somewhat the marginal tax rates while increasing the lifetime exemption in the years before 2010. See supra notes 43-44. But for transfers occurring in 2011 and beyond, it reinstates both the GST tax and the estate tax at their 2001 levels. Accordingly, unless one is certain that one will die in 2010, both the GST tax and the estate tax remain highly relevant considerations in estate planning. See, e.g., Report on Reform of Federal Wealth Transfer Taxes, 58 TAX L. 93, 107-16 (2004) (hereinafter Report on Reform). On the political economy of EGTRRA and the estate tax repeal movement, see MICHAEL J.

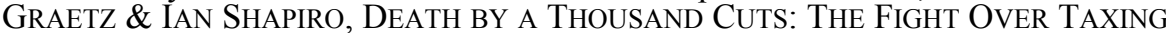
INHERITED WEALTH (2005); see also David G. Duff, The Abolition of Wealth Transfer Taxes: Lessons from Canada, Australia and New Zealand, Univ. of Toronto Leg. Stud. Res. Pap. No. 05-08, available at http://ssrn.com/abstract=719744.

51. See text accompanying infra notes 117-119;Schanzenbach \& Sitkoff, supra note 12 .

52. To put the learning difficulties into perspective, consider that USRAP was amended in 1990 - four years after its promulgation and the enactment of the GST tax, both in 1986-because of a potential tax problem (irrelevant for this Essay) arising from the interaction of the two. See USRAP \$1(e); Dukeminier, Perils, supra note 33 , at $187-94$.

53. State courts regularly cited the same leading authorities, namely, the 1959 Restatement (Second) of Trusts and the current versions of the Scott and Bogert treatises. See John H. Langbein, The Uniform Trust Code: Codification of the Law of Trusts in the United States, 15 Tr. L. Int'l 66, 67 \& n.3 (2001) (noting the perva- 
state perpetuities law became increasingly differentiated. Inasmuch as South Dakota does not levy a tax on trust income, but Idaho does and Wisconsin did until recently, South Dakota became a premier trust fund situs once the bar figured out the perpetuities loophole in the GST tax. Given prevailing choice-of-law principles ${ }^{54}$ and the shift in the nature of wealth from land to financial assets (making trust assets portable), ${ }^{55}$ it was only a matter of time until jurisdictional competition sparked a race to abolish the Rule Against Perpetuities.

To ensure that the law of state $B$ will govern the validity and administration of a trust created by a settlor who resides in state $A$, lawyers usually advise the settlor not only to provide in the trust instrument that the law of state $B$ is to govern, but also to name a trustee located in state $B$ and to give that trustee custody of the trust fund. As a result, an out-of-state settlor who wants to invoke the law of state $B$ will typically appoint as trustee a bank or trust company located in state $B$. Therein lies the payoff to state $B$ and the political economy of the RAP's demise. Ever since South Dakota's advantage was understood, abolition of the RAP has been "pushed by banking associations ... [that] wish to remain competitive with banks where perpetual trusts are permitted." J6 Joel Dobris puts it more bluntly: "When the bankers want something, they get it."

To be sure, the statutory law of South Dakota and the other abolition states does not expressly require naming an in-state trustee as a predicate to creating a perpetual trust. But the settlor is well advised to do so in order to provide a nexus with the state whose law is being invoked. Such a nexus increases the odds that another state's courts will respect the settlor's choice-of-law provision. ${ }^{58}$ Further, several of

sive influence of the Restatement (Second) of Trusts, "which has long been the most authoritative source for American trust law").

54. RESTATEMENT (SECOND) OF CONFLICT OF LAWS $\S \S 270,272$ (1971).

55. See John H. Langbein, The Twentieth-Century Revolution in Family Wealth Transmission, 86 MiCH. L. REV. 722 (1988).

56. DUKEMINIER \& JOHANSON, supra note 33, at 854; see also Rachel Wolcott, New Jersey Poised to Allow Dynasty Trusts, PRIVATE Asset MANAGEMENT, May 17, 1999, at 1 (stating that the New Jersey legislation, which was "sponsored by the New Jersey Bankers Association, was drawn up so that New Jersey trust institutions could avoid losing potential dynasty trust business and other types of trust business to Delaware, South Dakota, and Alaska”); A. 2804, 208th Leg. (N.J. 1999) (stating that the purpose of repeal was "to permit banks and trust companies to offer 'dynasty trusts' to their customers, such as those that are being offered by banks and trust companies located in other states").

57. Joel C. Dobris, Changes in the Role and the Form of the Trust at the New Millennium, or, We Don't Have to Think of England Anymore, 62 ALB. L. REV. 543, 572 (1998).

58. See 1 Jeffrey A. Schoenblum, Multistate and Multinational EsTATE PlANNING $\S 17.01[\mathrm{~F}]$, at $1166-69$ (2d ed. 1999); Sterk, supra note 32, at 2101-04 (2003). We say increases the odds because as yet there is no definitive caselaw. See Jeffrey A. Schoenblum, Reaching for the Sky-or Pie in the Sky: Is 
the abolition states have enacted statutes that provide that the appointment of an in-state trustee, while not necessary, is sufficient to ensure jurisdiction in that state's courts and the applicability of that state's law. ${ }^{59}$

We do not claim that there are no transaction costs in moving financial assets to another state or that it is not simpler to name as trustee a local bank rather than an out-of-state bank. But for wealthy donors these costs and inconveniences may be worthwhile given the transfer tax savings - roughly fifty cents on the dollar - available to subsequent generations if the trust can endure in perpetuity. As Stewart Sterk explains, naming an out-of-state "institution as trustee represents an insignificant constraint. Capital is extraordinarily mobile, so whether the trust property constitutes securities or cash, it will make little difference to the settlor whether legal title is held by" a local or an out-of-state bank. ${ }^{60}$

For a variety of historical reasons, Delaware - the hegemon of corporate regulatory competition-has long been a trust-friendly jurisdiction and by 1986 had a disproportionate share of the nation's trust funds. ${ }^{61}$ Indeed, prior to the GST tax, on several occasions Delaware tweaked its perpetuities law to create tax and other advantages to settling a trust in Delaware. ${ }^{62}$ So it was hardly a surprise

U.S. Onshore Trust Reform an Illusion?, in EXTENDING THE BOUNDARIES OF TRUSTS AND OTHER RING-FENCED FUNDS 291, 297-302 (David Hayton ed., 2002).

59. See, e.g., Alaska Code § 13.36 .035 (2004); OHIO REv. CodE AnN. $\S$ 2131.09(B)(2)(b) (2002); R.I. GEN. LAWS $\S 18-1-2$ (2003); S.D. CODIFIED LAWS $\S$ 55-3-39 (Michie 2001); see also ALASKA CODE $§ 13.36 .043$ (2004) (providing for change of situs to Alaska). See generally Larry E. Ribstein, Delaware, Lawyers, and Contractual Choice of Law, 19 DEL. J. CORP. L. 999 (1994) (examining use of choice-of-law statutes to facilitate jurisdictional competition).

60. Sterk, supra note 32, at 2104.

61. In regressions reported in a forthcoming study using state-level panel data from 1969 through 1984, we find that Delaware's aggregate trust business in that time period greatly exceeded that which would be predicted based on its population and income. See Schanzenbach \& Sitkoff, supra note 12. Thus, in 1986 Delaware's share of all trust funds held by federally reporting trustees was eight times larger than its share of the population $(2 \%$ versus $0.25 \%)$. To make these figures less abstract, consider that in 1986, when New York institutional trustees held $\$ 3,500$ in trust assets per state resident, Delaware institutional trustees held $\$ 12,600$ in trust assets per state resident. Delaware's dominant position is also apparent in infra Figure 2.

62. In 1986 Delaware established a 110-year perpetuities period for property held in trust. Delaware had earlier enacted a statute which provided that a new perpetuities period would begin on the exercise of a power of appointment. See Del. Code Ann. tit. 25, § 501 (1989). Hence Delaware made possible a perpetual trust long before 1995. However, Congress effectively foreclosed this option with I.R.C. $\S 2041(\mathrm{a})(3)$, which makes the extension of the perpetuities period under $\S 501 \mathrm{a}$ taxable event for all trusts created in or after 1942. See Jonathan G. Blattmachr \& Jeffrey N. Pennell, Adventures in Generation-Skipping, or How We Learned to Love the “Delaware Tax Trap,” 24 REAL PROP. PROB. \& TR. J. 75 (1989); DuKEMINIER ET AL., supra note 4, at 694-95. 
when in 1995 Delaware became the first state after the enactment of the GST tax to abolish the Rule as applied to interests in trust. ${ }^{63}$ The bill's official synopsis makes its purpose plain:

Several states, including Idaho, Wisconsin and South Dakota, have abolished altogether their rules against perpetuities, which has given those jurisdictions a competitive advantage over Delaware in attracting assets held in trusts created for estate planning purposes....

The multi-million dollar capital commitments to these irrevocable trusts, and the ensuing compound growth over decades, will result in the formation of a substantial capital base in the innovative jurisdictions that have abolished the rule against perpetuities. Several financial institutions have now organized or acquired trust companies, particularly in South Dakota, at least in part to take advantage of their favorable trust law.

Delaware's repeal of the rule against perpetuities for personal property held in trust will demonstrate Delaware's continued vigilance in maintaining its role as a leading jurisdiction for the formation of capital and the conduct of trust business. ${ }^{64}$

The Delaware statute triggered a race to abolish the Rule. Between 1997 and 2000, Alaska, Arizona, Illinois, Maine, Maryland, New Jersey, Ohio, and Rhode Island authorized perpetual trusts. By year end 2004, Colorado, Florida (360 years), Missouri, Nebraska, New Hampshire, Utah (1,000 years), Virgina, and Wyoming (1,000 years) had followed suit. In 2005 Nevada extended its perpetuities period to 365 years. $^{65}$ Legislation designed to abolish the Rule Against Perpetuities is under consideration in several other states. ${ }^{66}$

The following maps illustrate the spread of the Rule's abolition. The first illustrates the extent of the Rule at the time the GST tax was enacted; the second shows the extent of the Rule in 1995, when Delaware acted; and the final two maps, which present the extent of the Rule at year end 1998 and 2004, show the increasingly rapid pace of the Rule's abolition.

\section{[ME: Insert first four maps here]}

Before moving on, it is necessary to acknowledge some doctrinal nuances that we gloss over when we speak of the Rule's abolition.

63. See 70 Del. Laws 164 (1995).

64. H.B. 245, 138th Gen. Assemb., (Del. 1995).

65. See 2005 Nev. Laws Ch. 270 (S.B. 64) (effective October 1, 2005). This legislation supersedes an earlier 2005 enactment extending the perpetuities period to 150 years. See 2005 Nev. Laws Ch. 163 (S.B. 382).

66. See Tate, supra note 32 , at 604 n.45 (collecting pending legislation). 
Some states have abolished the Rule altogether. Some states have abolished it as applied to interests in trust if the trustee has the power to sell the trust assets and then reinvest the proceeds (in the technical jargon, as applied to trusts that do not suspend the power of alienation). Some states have abolished the Rule as applied to interests in personal property. Some have established such lengthy perpetuities periods (360 or even 1,000 years) that in those states the Rule is barely recognizable. In still others, the Rule, which had always been construed as a mandatory rule to curtail the dead hand, ${ }^{67}$ has been changed to a default rule that applies unless the settlor provides otherwise.

The subtle distinctions among these approaches have been carefully parsed elsewhere. ${ }^{68}$ For the purpose of this study, all that matters is whether the state's perpetuities law permits a perpetual trust. If the answer is yes, we count the state as having abolished the Rule. Our coding is detailed in Table 5.

\section{Additional Margins of Competition}

In general, there is little variation in the basic law of trusts across the states. ${ }^{69}$ Moreover, the law of trusts is comprised largely of default rules that may be varied by the settlor. ${ }^{70}$ Accordingly, apart from state perpetuities law, in the usual case there is little reason to

67. Gray expressed this view in stronger language:

The Rule against Perpetuities is not a rule of construction, but a peremptory command of law. It is not, like a rule of construction, a test, more or less artificial, to determine intention. Its object is to defeat intention. Therefore every provision in a will or settlement is to be construed as if the Rule did not exist, and then to the provision so construed the Rule is to be remorselessly applied.

Gray, supra note 19 , at $\S 629$. On the oddity of transmogrifying rules of law into rules of construction, see RESTATEMENT (THIRD) OF PROPERTY: WILLS AND OTHER DONATIVE TRANSFERS $\S 16.3 \mathrm{cmt}$. a (Tentative Draft No. 4, 2004).

68. See Garrett Moritz, Note, Dynasty Trusts and the Rule Against Perpetuities, 116 HARV. L. REV. 2588, 2590-95 (2003); Tate, supra note 32, at 603 n.44. Readers familiar with the more arcane features of property law might ask about the rule against accumulations of income. In Delaware, Illinois, and South Dakota, which are among the most aggressive of the perpetual trust states, the legislatures have dealt with this question expressly. See DEL. CODE ANN., tit. 25, § 506 (Supp. 2004); 765 Ill. COMP. STAT. 315/1 (2001); 1998 S.D. CoDIFIED LAWS ch. 282, § 27 (Michie 1998). True, in states without legislative action, the law is less clear. But the common law accumulations period is the same as the perpetuities period. See Robert H. Sitkoff, The Lurking Rule Against Accumulations of Income, 100 Nw. U. L. REV. (forthcoming 2006). Thus, if the perpetuities period with respect to a particular trust is extended by repeal of the Rule, then the permissible accumulations period should be likewise extended. See id.I

69. See supra note 53.

70. See RESTATEMENT (ThiRd) OF TRUsts $\$ 4 \mathrm{cmt}$. a(1) (2003); John H. Langbein, Mandatory Rules in the Law of Trusts, 98 Nw. U. L. REV. 1105 (2004); Robert H. Sitkoff, An Agency Costs Theory of Trust Law, 89 CORNELl L. REV. 621, 64243 (2004). 
settle a trust out-of-state given the increased transaction costs of doing so.

In this section we explore the two primary exceptions to the foregoing proposition, both of which involve mandatory rules (so that switching states is the only means of obtaining choice on these matters): (1) statutory validation of self-settled asset protection trusts, and (2) state fiduciary income taxes. ${ }^{71}$ These are the principal addi-

71. This is not to say that these two factors, plus perpetuities law, exhaust the entire universe of rationales for choosing to settle a trust out-of-state in a particular case. However, based on a review of the scholarly and practitioner literature, as well as a series of interviews with lawyers and trust company officers, we are confident that these factors represent the only other motivations that are possibly of the same order of magnitude as the Rule Against Perpetuities. See, e.g., John A. Warnick \& Sergio Pareja, Selecting a Trust Situs in the 21st Century, PROB. \& PROP. 53 Mar.-Apr. 2002, at 53 (identifying perpetuities, asset protection, and state income taxes as the main considerations). In view of the size of total trust assets held by federally reporting institutional fiduciaries, phenomena that do not measure in the billions will not impact our analysis - and we are confident that we have not missed any billion-dollar phenomena. Even so, for the sake of completeness we note here the two most plausible additional considerations:

(1) Some readers might assume that the existence of a state death tax in the form of an estate or inheritance tax in excess of the credit formerly allowed against the federal estate tax could impact trust fund location. See I.R.C. $§ 2058$ (Supp. 2005); Jeffrey A. Cooper et al., State Estate Taxes After EGTRRA: A Long Day's Journey Into Night, 17 QUINN. PROB. L.J. 317 (2004); Report on Reform, supra note 50, at 103-07. However, with respect to intangible personal property, which is to say stocks, bonds, and other financial assets (the stuff of modern trust funds), by statute or interstate agreement state death taxes are typically levied by domicile of the decedent, not by location of the trust fund. See 2 JEROME R. HELLERSTEIN \& WAlter Hellerstein, State TAXATION I 21.09, at 21-47 (3d ed. 2003); 2 SCHOENBLUM, supra note 58, $\S 19.04$, at 29-30.. Escape from state death taxes thus requires changing one's domicile, a subject on which there is a separate empirical literature. See, e.g., JON BAKIJA \& JOEL SLEMROD, DO THE RICH FLEE FROM HIGH STATE TAXES? EVIDENCE FROM FEDERAL Estate TAX RETURNS (Nat'l Bureau of Econ. Research, Working Paper No. 10645, 2004); Karen Smith Conway \& Jonathan C. Rork, Diagnosis Murder: The Death of State Death Taxes, 42 ECON. INQUIRY 537 (2004). Moreover, in unreported regressions in which we coded states that levy an estate or inheritance tax in excess of the federal credit as YES and the others as NO, we found no significant correlation between a change from YES to $\mathrm{NO}$ and reported trust assets.

(2) Some readers might suppose that unitrust statutes will impact trust fund location. In a unitrust the settlor sets a percentage of the value of the trust corpus to be paid each year to the income beneficiary, thereby allowing the trustee to invest for total return by freeing her from arbitrary income and principal classifications. See DUKEMINIER ET AL., supra note 4, at 829. Although statutory recognition is not necessary to create an enforceable unitrust under state law, a state statute is necessary to convert an existing principal and income trust into a unitrust, and for all unitrusts a state statute is all but mandatory for a host of federal tax reasons. See Adam J. Wiensch \& L. Elizabeth Beetz, The Liberation of Total Return, TR. \& EST., Apr. 2004, at 44; Robert B. Wolf \& Stephan R. Leimberg, Total Return Trusts Approved by New Regs. But State Law is Crucial, 31 Est. PLAN. 179 (2004). On this view, the presence of a unitrust statute might be a reason to locate a trust in one state versus another. However, the earliest statute was enacted by Delaware in 2001, and most were enacted in later years. The phenomenon is thus too recent to be reflected in our data. Given our coding scheme of recording the year after adoption as the year of the legal change, this would give only a handful of state-year observations. 
tional margins, beyond perpetuities law, on which the states compete for trust funds. Because several states changed their law on one or both of these issues in the period under study, it is necessary to control for these factors in assessing the impact of the abolition of the Rule Against Perpetuities. A brief treatment of each yields additional testable hypotheses.

\section{Self-Settled Asset Protection Trusts ${ }^{72}$}

A longstanding principle of trust law holds that the settlor cannot shield assets from creditors by placing them in a trust for his or her own benefit. Even if the trust is discretionary, spendthrift, or both, the settlor's creditors can reach the maximum amount that the trustee can pay the settlor or apply for the settlor's benefit. ${ }^{73}$ Thus:

Case 4. Self-Settled Trust. $O$, a surgeon, transfers property to $X$ in trust to pay so much of the income and principal to $O$ as $X$ determines in $X$ 's sole and absolute discretion. Five years later, $O$ botches a routine surgery, causing grievous injury to the patient, $A$. A may enforce an award of damages against the entire corpus of the trust, because $X$ could, in $X$ 's discretion, pay the entire corpus to $O$. This result obtains even if the trust instrument provides that $O$ 's interest may not be reached by $O$ 's creditors (a spendthrift clause). Nor does it matter that $O$ 's right to the trust assets is subject to $X$ 's discretion.

In the latter part of the twentieth century, however, several offshore and domestic jurisdictions enacted statutes that reverse the traditional rule, thereby giving rise to the self-settled asset protection trust (APT). If such a statute were applicable in Case 4, then $A$ would have no recourse against the assets in the trust even if $O$ admitted to botching A's surgery and put up no defense in the malpractice suit.

The story of the recognition of APTs begins in the sunny Caribbean, South Pacific, and other exotic offshore locales. In the 1980s, a host of such jurisdictions - including Antigua, Bahamas, Barbados, Belize, Bermuda, Cayman Islands, Cook Islands, Cyprus, Gibraltar, Grenada, Isle of Man, Jersey, Liechtenstein, Mauritius, Nevis, Samoa, St. Lucia, and Turks and Caicos-amended their trust laws to allow the creation of a self-settled trust against which the settlor's

72. Portions of this section draw on DUKEMINIER ET AL., supra note 4, at 55760, 566-69.

73. See RESTATEMENT (SECOND) OF TRUSTS $\$ 156$ (1959). These rules are carried forward in UNIFORM TRUST CODE $\S 505$ (2000) and RESTATEMENT (THIRD) OF TRUSTS $\S \S 58(2), 60 \mathrm{cmt}$. f(2003). 
creditors have no recourse. ${ }^{74}$ Although it has been conjectured that the value of offshore APTs exceeds $\$ 1$ trillion, ${ }^{75}$ no reliable empirical study exists.

The APT migrated onshore in 1997 in the form of an innovative Alaska statute. This statute was drafted by a prominent New York trust lawyer, his brother (who is now the head of the Alaska Trust Company), and an Alaska lawyer. The three had the idea while on a fishing trip in Alaska. ${ }^{76}$ Under the Alaska statute, the settlor's creditors have no recourse against the settlor's interest in a self-settled discretionary trust provided that the initial transfer was not fraudulent. ${ }^{77}$ To ensure a local payoff, Alaska law provides that, if an Alaska resident or banking institution is designated as trustee and some of the trust assets are deposited with an Alaska institution, both jurisdiction in the Alaska courts and the applicability of Alaska law will be ensured. ${ }^{78}$

In 1997 Delaware likewise validated APTs. ${ }^{79}$ The official synopsis

74. See Denis Kleinfeld, Choosing an Offshore Jurisdiction, in AssET PROTECTION STRATEGIES: PlanNING WITH DOMESTIC AND OFFSHORE ENTITIES 73 (Alexander A. Bove, Jr. ed., 2002); Elena Marty-Nelson, Offshore Asset Protection Trusts: Having Your Cake and Eating It Too, 47 RUTGERS L. REV. 11, 62 (1994); see also Lynn M. LoPucki, The Death of Liability, 106 YALE L.J. 1, 32-40 (1996) (discussing "foreign haven strategies"). The Cook Islands' International Trusts Act of 1984, which is representative, validates self-settled spendthrift trusts, provided that the beneficiary is not a resident of the Cook Islands. International Trusts Act \$5(1) (last amended 1999) (Cook Islands). As Sterk has observed, this qualification is "a sure sign that the purpose of the statute was to attract foreign capital." Stewart E. Sterk, Asset Protection Trusts: Trust Law's Race to the Bottom?, 85 CORNELL L. REV. 1035,1048 (2000).

75. See 1 Walter H. Diamond, ET Al., InTERnational Trust LaWs and ANALYSIS FRW-1 (2004); see also Sterk, supra note 74, at 1036 (stating that "conservative estimates exceed one trillion dollars").

76. See Alaska Trust Co., The Genesis of the Alaska Trust Company, The Alaska TRUST ACT, AND OTHER UniQue TRUST LEGISLATION, http://www.alaskatrust.com/www/thegen.html; James L. Dam, New Trusts Will Offer Estate Tax Breaks, Protection from Creditors, LAW. WKLY., Apr. 21, 1997, at 1 (including a photo of one of the fish caught); Brigid McMenamin, Flimsy Shelters, ForBES, Sept. 8, 1997, at 94; Douglas J. Blattmachr \& Jonathan G. Blattmacher, A New Direction in Estate Planning: North to Alaska, TR. \& EsT., Sept. 1997, at 48. Representative Al Vezey sponsored the legislation. See Hearings on H.B. 101 Before the Subcommittee on Labor and Commerce, 20th Leg. (Alaska 1997) (statement of Rep. Vezey); Rose Ragsdale, Opposing Parties Join Forces to Attract Family Trust Industry to Alaska, AlASKA J. COMM., Aug. 14, 1997. On passage of the Act the local media and Alaska lawyers and bankers predicted a substantial inflow of trust business. See Carrie Lehman, Legislation Changes Alaska Tax, Trust Laws, Attracts New Investors to State, AlASKA J. CoMm., Aug. 18, 1997, at 1; Deanna Thomas, Trust Bill Could Mean Boon, AlASKA STAR, Mar. 20, 1997, at 1; Katharine Fraser, With New Law, Alaska Aiming to Be Trust Capital, AM. BANKER, Apr. 21, 1997, at 1.

77. AlASKA CODE $\$ 34.40 .110$ (Michie 2004).

78. Id. $\S 13.36 .035$. A subsequently enacted provision authorizes transfer of existing trusts to Alaska. Id. $\S 13.36 .043$.

79. DEL. CODE ANN. tit. 12, $\S \S 3570-76$ (year). The Delaware statute carves out an exception for support claims by children and former spouses and for claims arising from death, personal injury, or property damage that occurred before the trust 
of the Delaware Act states that it "is similar to legislation recently enacted in Alaska. It is intended to maintain Delaware's role as the most favored domestic jurisdiction for the establishment of trusts." ${ }^{80}$ Since then, Nevada (1999), Rhode Island (1999), Oklahoma (2004), and Utah (2004) have passed statutes authorizing some form of APT, bringing the domestic count to six. ${ }^{81}$

\section{[ME: Insert map 5 here]}

Similar legislation has been introduced in other states. ${ }^{82}$ Most of the APT statutes condition their applicability on the appointment of an instate trustee. ${ }^{83}$ But even if a state's APT statute does not require naming an in-state trustee, a well-advised settlor will do so anyway to increase the odds that courts in other states will respect the trust's choice-oflaw provision. ${ }^{84}$

The political dynamic driving the validation of APTs is similar to that which drives the movement to abolish the Rule Against Perpetuities. Local banks and lawyers, who stand to benefit from an influx of trust assets, are the principal interests that have supported APTs. But

was settled. Id., § 3573; see also Richard W. Nenno \& John E. Sullivan, III, Delaware Asset Protection Trusts: Avoiding Fraudulent Transfers and Attorney Liability, 32 EST. Plan. 22 (2005); Nenno, supra note 49, at $§ 74$.

80. 71 Del. Laws 159 (1997). See Douglas J. Blattmachr \& Richard W. Hompesch II, Alaska vs. Delaware: Heavyweight Competition in New Trust Laws, PROB. \& Prop., Jan./Feb. 1998, at 32 (1998); Todd Spangler, Delaware Again 1st in Trusts, ANCHORAGE DAILY NEWS, July 29, 1997, at 1F.

81. See NEV. ReV. StAT. § 166.040(1)(b) (2003); OK. St. AnN. tit. 31, §§ 10-18 (Supp. 2005); R.I. GEN. LAWS §§ 18-9.2-1 to18-9.2-5 (2003); UTAH CODE ANN. § 256-14 (Supp. 2004). Some commentators have read an older statute in Colorado to authorize self-settled asset protection trusts as to future creditors, see COLO. REV. STAT. § 38-10-111, but in dicta the Colorado Supreme Court has rejected that interpretation. In re Cohen, 8 P.3d 429, 432-34 (Colo. 1999). In 1986 Missouri amended its statutory rules on spendthrift trusts in a manner that could be read to authorize APTs, see MO. STAT. § 456.080 (superseded statute), but there is some contrary case law and the literature tends not to regard Missouri an APT jurisdiction. See Markmueller v. Case, 51 F.3d 775 (8th Cir. 1995); John K. Eason, Retirement Security Through Asset Protection: The Evolution of Wealth, Privilege, and Policy, 61 WASH. \& LEE L. REV. 159, 174 n.54 (2004). Hence we code neither Colorado nor Missouri as APT jurisdictions. In 2004 Missouri adopted a nonuniform version of UNIFORM TRUST CODE $§ 505$ (2000) that took effect on January 1, 2005, see Mo. STAT. $§ ~ 456.5-505.3$, and its drafters intended specifically to authorize APTs. See James G. Blase, 61 J. Mo. B. 72 (2005). Whether the new Missouri statute in fact authorizes APTs does not bear on this study because it took effect after the timeframe of our data.

82. See, e.g., An Act to Amend the Estates, Powers and Trusts Law, in Relation to Qualified Dispositions in Trust, Assemb. B. 2173, 226th Ann. Leg., Reg. Sess. (N.Y. 2003).

83. See Del. Code AnN. tit. 12, § 3570(9) (2001); OK. ST. ANN. tit. 31, § 11 (Supp. 2005); R.I. GEN. LAWS $\S \S 18-9.2-2(8)$ (2003); UTAH CODE ANN. § 25-614(10) (Supp. 2004).

84. See text accompanying supra notes 54-60. 
where the abolition of the Rule Against Perpetuities is driven by the desire of settlors to provide a transfer-tax-exempt trust for future generations, it is the settlor's personal liability exposure that drives the APT market. For example, there is anecdotal evidence that, in the face of rising premiums, some doctors have opted to drop their malpractice insurance altogether in favor of moving their assets into APTs (this is the motivation for Case 4, above). ${ }^{85}$ Indeed, the validation of APTs is sometimes defended on the ground that tort liability is "out of control." ${ }^{.86}$ On this account, APTs "might be reckoned as the revenge of the trust lawyers against the tort lawyers.",87

It remains to be seen whether the courts of states that adhere to the traditional rule will respect domestic APTs. ${ }^{88}$ In spite of this uncertainty, however, validation of APTs is a potentially important distinguishing feature in the competition for trust funds. To the extent that an APT gives the settlor additional settlement leverage in negotiations with creditors, an APT has value, although just how much is uncertain. ${ }^{89}$ Thus, as with the abrogation of the Rule Against Perpetuities, validation

85. See Rachel Emma Silverman, Litigation Boom Spurs Efforts to Shield Assets, Wall ST. J., Oct. 14, 2003, at D1; Rachel Emma Silverman, So Sue Me: Doctors Without Insurance, WALL ST. J., Jan. 28, 2004, at D1.

86. Roundtable Discussion, 32 VAND. J. TRANSNAT'L. L. 779, 793-94 (1999).

87. DUKEMINIER ET AL., supra note 4, at 558.

88. Although there are not yet any definitive appellate decisions involving domestic APTs, there is a cautionary scholarly literature that explores bankruptcy law, fraudulent conveyance law, choice of law principles, federal Constitutional limits (such as the Contract and the Full Faith and Credit Clauses), and other doctrinal bases for refusing enforcement. This literature also takes on the normative policy question. See Karen E. Boxx, Gray's Ghost-A Conversation About the Onshore Trust, 85 IowA L. REV. 1195 (2000); John K. Eason, Developing the Asset Protection Dynamic: A Legacy of Federal Concern, 31 HoFsTRA L. REV. 23 (2002); Randall J. Gingiss, Putting a Stop to “Asset Protection” Trusts, 51 BAYLOR L. REV. 987 (1999); Henry J. Lischer, Jr., Domestic Asset Protection Trusts: Pallbearers to Liability?, 35 REAL PROP. PROB. \& TR. J. 479 (2000); Sterk, supra note 32. For a contrary academic view, see Robert T. Danforth, Rethinking the Law of Creditors' Rights in Trusts, 53 HASTINGS L.J. 287 (2002). There are also numerous articles by or for practitioners. See, e.g., John E. Sullivan III, Gutting the Rule Against SelfSettled Trusts: How the New Delaware Trust Law Competes With Offshore Trusts, 23 DEL. J. CORP. L. 423 (1998); Melanie Leslie, Asset Protection Trusts Find a Home in the United States, N.Y.L.J., Feb. 14, 2005, at S1; David G. Shaftel \& David H. Bundy, Domestic Asset Protection Trusts Created by Nonresident Settlors, EST. Plan., Apr. 2005 at 17; David G. Shaftel \& David H. Bundy, Domestic Asset Protection Trusts and the Bankruptcy Challenge, 32 EsT. PLAN. 14 (2005). Offshore APTs have met with considerable judicial hostility, see, e.g., In re Lawrence, 279 F.3d 1294 (11th Cir. 2002); Federal Trade Commission v. Affordable Media, LLC, 179 F.3d 1228 (9th Cir. 1999), though some view these cases as cautionary tales on how not to draft an offshore trust. See Alexander A. Bove, Jr., Drafting Offshore Trusts, TR. \& EST., July 2004, at 45-46.

89. Eric Henzy, who represented the plaintiff in In re Brooks, 217 B.R. 98 (Bkrtcy. D. Conn. 1998), explains: "In Brooks we got a judgment essentially voiding this offshore trust. We then settled for approximately fifty cents on the dollar, because the enforcement problems were so significant." Roundtable Discussion, supra note 86 , at 786 . 
of APTs has the potential to attract trust funds. We code for APTs as summarized in Table 5.

\section{Fiduciary Income Taxes}

Suppose $O$, a prospective settlor who resides in state $A$, wants the law of state $B$ to govern the administration and validity of her trust. As we have seen, to achieve this end $O$ will often be advised not only to designate in the trust instrument that the law of state $B$ is to govern, but also to name a bank or trust company located in state $B$ as trustee. ${ }^{90}$ In doing so, a relevant concern to the settlor is whether as a result state $B$ will levy a tax on the trust's income. Such a tax is called a fiduciary income tax (FIT) because the fiduciary is responsible for filing the return and paying the tax.

To ascertain whether differences in state FIT regimes affect the location of trust funds, we must first attend to the federal taxation of trust income, under which trusts are treated as conduit or passthrough entities. ${ }^{91}$ Income distributed to a beneficiary in the year it is received is taxable to the beneficiary, not to the trust; income that is not so distributed is taxable to the trust, not the beneficiary. Hence, from the perspective of minimizing federal income taxes, trust income should be distributed or accumulated depending on the relative applicable tax rates.

In the period under study, the rates applicable to individuals were significantly less than those applicable to trusts. ${ }^{92}$ Indeed, as Jeffrey Pennell has remarked, the rates applicable to trusts "by far are the most onerous applicable to any taxpayer under the Code." "93 The Internal Revenue Code thus creates an incentive for trust income to be distributed to the beneficiary in the year it is received. ${ }^{94}$

States that levy a FIT tend to follow a similar conduit model. ${ }^{95}$ As a result, for many trusts state FITs are avoided in the course of avoid-

90. See text accompanying supra notes 54-60.

91. See Jeffrey G. Sherman, All You Really Need to Know About Subchapter J You Learned from This Article, 63 Mo. L. REV. 1, 12 (1998).

92. See Sherman, supra note 91, at 5, 37-38; 1 CCH STANDARD FEDERAL TAX REPORTER 1987 \$421.05 (74th ed. 1986). The current rates are stated in I.R.C. $\S$ 1(a)-(d) for individuals and (e) for estates and trusts.

93. PENNELL, supra note 14, at 17-2.

94. See McGovern \& Kurtz, supra note 27 , at 705 . Even if the trustee has discretion not to make distributions, the trustee's duty of prudence requires reasonable efforts to minimize taxes. See Mark L. Ascher, The Fiduciary Duty to Minimize Taxes, 20 REAL Prop. Prob. \& TR. J. 663 (1985).

95. MAX Gutierrez \& Frederick R. Keydel, ACTEC Study 6: StATE TAXATION ON InCOME of TRUSTS With Multi-StATE CONTACTS 12 (2001); Bradley E.S. Fogel, What Have You Done For Me Lately? Constitutional Limitations on State Taxation of Trusts, 32 U. RicH. L. REV. 165, 173-74 (1998). 
ing federal income tax. We therefore hypothesize that, by itself, whether a state levies a FIT on trust funds attracted from out of state will have little to no observable affect on trust fund location. ${ }^{96}$

Unlike an ordinary trust, however, a transfer-tax-exempt perpetual trust has a different duration and purpose that might warrant accumulation of income notwithstanding the federal income tax penalty. Income accumulated in a transfer-tax-exempt trust is exempt from subsequent wealth transfer taxation, but such income loses its exempt status upon distribution to a beneficiary. The federal income tax penalty is not trivial, but it pales in comparison to the current $47 \%$ top rate of the federal transfer taxes. In contrast to the income tax, which reduces the trust's rate of growth, the transfer taxes eat into the corpus of the trust. Hence, for a transfer-tax-exempt perpetual trust, it may be a sensible long-term strategy to incur a present income tax liability to avoid a bigger future transfer tax bill. Further, unless some income is retained, the trust will lose value because of inflation, a significant consideration if the trust's purpose is to provide a fund for future generations.

Although a settlor cannot avoid the federal income tax penalty by switching states, she can avoid piling on state income taxes by choosing a state that does not tax income in trusts attracted from out of state. Accordingly, we predict that the effect of the abolition of the Rule will be magnified in states that do not tax income in trust funds attracted from out of state. Once the settlor has committed to incurring the costs of settling an out-of-state trust, the marginal cost of choosing a state that will not levy a FIT on the trust's income is close to zero but the benefits are potentially significant.

Each state has a "unique matrix of statutory rules" setting forth what contacts with the state will trigger FIT liability. ${ }^{97}$ Based on our examination of the FIT statutes of all fifty states from 1985 through 2004, we have coded each state as YES or NO for each year pursuant to the following standard of relevance: Relevant FITs are those that would be levied on income in a trust (1) consisting entirely of financial assets (in the jargon, intangible personal property) that is (2) settled by a nonresident (3) for the benefit of a nonresident. Moreover, such taxes are relevant only if they would be triggered even if the

96. Further, the trustee may deduct state income taxes in figuring the trust's federal income tax. But a deduction is not the same as a credit-a consideration that, for the reasons discussed in the next paragraph, is likely to be of greater significance for a transfer-tax-exempt perpetual trust. See also Bradley E.S. Fogel, State Income Taxation of Trusts, PROB. \& PROP. Jul.-Aug. 2005, at 39 (examining state taxation of accumulations in trust).

97. Jeffrey A. Schoenblum, 2004 Multistate Guide to Estate Planning 
trust's only contact with the state is (a) an in-state trustee, (b) in-state administration, or (c) in-state situs. We use this standard of relevance because it characterizes the paradigmatic trust fund attracted from out of state and our estimation strategy measures relative increases in the states' reported trust assets. Settling an out-of-state trust with an outof-state trustee is the primary method of avoiding state FITs other than changing the settlor's or the beneficiary's state of residence. For the rest of this Essay, when we speak of state taxation of income in trusts attracted from out of state, we refer to the six conditions stated above. In the absence of clarifying regulations or caselaw, we resolved statutory ambiguity in favor of YES.

Our FIT coding, which is consistent with the methodology of Jeffrey Schoenblum's annual Multistate Guide to Estate Planning, ${ }^{98}$ is summarized in Table 5. Crucially, there is variation across states and some variation across time, which allows us to test the importance of FITs on their own as well as their interactive effect with abolition of the Rule Against Perpetuities.

\section{DESCRIPTION OF THE DATASET}

\section{A. Data Sources}

The trust data (state-level panel data) come from annual reports collected by the four federal agencies charged with banking regulation: (1) the Federal Deposit Insurance Corporation; (2) the Federal Reserve System; (3) the Office of Thrift Supervision; and (4) the Office of the Comptroller of the Currency. All banks and other financial institutions that are regulated by these agencies must file an annual report detailing their trust holdings, including total assets and number of accounts. Federal statutes make these filings mandatory. ${ }^{99}$ Based on this data, from 1968 until 2001 the Federal Financial Institutions Research Council published annual reports of trust holdings by regulated entities, summarizing the results by state. ${ }^{100}$ Since 2001 , the FDIC has been publishing these reports (now available online) organized by individual institution and by state. ${ }^{101}$

98. See id., at tbl.11.

99. 12 U.S.C. $§ 1817$ (FDIC); Id. $\S \S 248(\mathrm{a}), 1844(\mathrm{a})$ (Federal Reserve System); Id. $\S \S 1464,1725,1730$ (Federal Home Loan Bank Board); Id. $\S \S 161,1817$ (Office of Comptroller of the Currency).

100. FEDERAL FinANCIAL Institutions Examination COUnCIL, Trust AsSETS OF FINANCIAL INSTITUTIONS, 1985-2000.

101. An interactive website allows one to obtain new data, state by state at FDIC: Statistics on Depository Institutions, http://www2.fdic.gov/sdi/main.asp. Older reports, from 1996 through 2000, may be obtained at FFIEC: Trust Institutions Information, http://www2.fdic.gov/structur/trust/index.asp. 
The trust holdings of regulated entities are reported in categories entitled "Employee Benefit," "Personal Trusts," and "Estates." We examine only "Personal Trusts," a category that includes both private and charitable trusts (both testamentary and inter vivos), but that excludes commercial trusts and employee benefit plans. Prior to 1985, federal authorities only collected information on actively managed personal trusts (meaning trusts for which the regulated entity had discretionary investment authority), and neither savings-and-loan institutions nor savings banks with trust powers were required to report. ${ }^{102}$ To ensure consistency we use only data from 1985 onward. ${ }^{103}$

In some specifications, we include additional variables from yearly estimates of state population and personal income. ${ }^{104}$

\section{B. Brief Treatment of Data Limitations}

In Appendix A, we provide a treatment of the limitations of our data. In this section, we examine the most serious concern about the data, namely, whether recent bank mergers and consolidations exaggerated the movement in trust assets we observe.

Effective in 1997, the Riegle-Neal Interstate Banking and Branching Efficiency Act of $1994^{105}$ made it much easier for banks and bank holding companies to convert independently chartered banks in different states into branch offices of a single interstate bank. ${ }^{106}$ Interstate bank mergers or branch consolidations have the potential to bias our results because the data are collected by institution, not by state. For example, if a bank consolidated after 1997 by

102. See Federal Financial Institutions ExAmination Council, TRust ASSETS OF FINANCIAL INSTITUTIONS-1987, at 2 for a discussion.

103. Most states that abolished the RAP did so beginning in the mid-1990s. Hence, limiting our study to the years since 1985 provides a sufficient number of pre-abolition observations. We also have two years of observations prior to the Tax Reform Act of 1986. We examine the data from 1969 through 1984 in a forthcoming study. See Schanzenbach \& Sitkoff, supra note 12.

104. Yearly state population estimates are available at Population Estimate Archives, http://www.census.gov/popest/archives/. Yearly state personal income estimates are available at Bureau of Economic Analysis: Regional Economic Accounts, http://www.bea.gov/bea/regional/statelocal.htm. Income estimates are given quarterly. We used the estimates in the December reports because the reporting institutions reported trust assets at year end.

105. Pub. L. No. 103-328, 1994 U.S.C.C.A.N (108 Stat.) 2338 (1994) (codified at 12 U.S.C. $\S 1811(2000))$. See Patrick Mulloy \& Cynthia Lasker, The RiegleNeal Interstate Banking and Branching Efficiency Act of 1994: Responding to Global Competition, 21 J. LEGIS. 255, 270-72 (1995).

106. Prior to 1997 , banks could maintain interstate branches under narrow circumstances, but a study conducted by the Federal Reserve found that few banks did so. Susan McLaughlin, The Impact of Interstate Banking and Branching Reform: Evidence from the States, CURRENT ISSUES IN ECONOMICS AND FINANCE, May 1995. 
converting its independently chartered offices in state $A$ into a branch of its headquarters bank chartered in state $B$, then trust assets formerly reported as held in state $A$ would from that point forward be reported as held by the headquarters bank in state $B$. Mergers could have the same effect. If a bank chartered in state $A$ acquired a bank chartered in state $B$ and then converted the acquired bank into a branch, the accounts formerly reported as held in state $B$ would be reported as held in state $A$.

Although important to consider, this limitation does not present a significant impediment to our study. For mergers to bias our results upward (that is, to produce a falsely positive finding), a bank in an abolition state would have to acquire a bank in a RAP state and then report the acquired bank's trust assets as held in the abolition state. Using a list of all bank mergers since 1991 in which the acquired bank had total assets over $\$ 20$ billion, ${ }^{107}$ we identified only one merger of a bank from a RAP state into an abolition state - the 1995 merger of Shawmut National, headquartered in Massachusetts, with Fleet Financial, headquartered in Rhode Island. For this reason, we exclude observations from Massachusetts and Rhode Island for the affected years. We also run a specification that excludes these two states for all years. ${ }^{108}$ The results are not meaningfully different. In addition, a recent Federal Reserve study found that bank headquarters have been moving from small cities to larger cities (particularly New York City) over the $1990 \mathrm{~s},{ }^{109}$ but most of the abolition states are small and lack large cities.

As a further check, we also use average account size as a dependent variable. Average account size is computed by dividing total reported assets by the number of reported accounts. A swing up or down in reported assets caused by a merger should be correlated with a corresponding swing up or down in the number of accounts. Thus, average account size should be less sensitive than total assets to dis-

107. Robert DeYoung \& Thomas Klier, Fed. Res. BANK OF Chi., Fed Letter No. 201, Why BankOne left Chicago: One Piece in a Bigger Puzzle, 3 tbl.3 (2004), available at

http://www.chicagofed.org/publications/fedletter/aflapril2004_201.pdf.

108. In 1998, the same year that Illinois abolished the RA $\bar{P}$, First Bank of Chicago and Bank One of Columbus, Ohio merged, with the headquarters remaining in Chicago. However, based on institution-level data for 2001 obtained from the FDIC's website, it appears that First Bank continues to report as an Ohio bank, and Ohio abolished the RAP in 1999. There were some significant mergers between control states (California and North Carolina for example), which cause substantial swings between those states in reported assets. But as these mergers simply shifted money between control states, they should not have an effect on our coefficient estimates.

109. Tyler Diacon \& Thomas H. Klier, Where the Headquarters are-Evidence from Large Public Companies 1990-2000, at 6 (Fed. Res. Bank of Chi., Working Paper No. 35, 2003). 
tortion from mergers or branching. Average account size is also a meaningful variable in its own right for reasons we discuss in the empirical analysis below.

\section{EMPIRICAL ANALYSIS}

Our analysis of the data proceeds in three steps. First, in Section A we present an initial discussion of the raw data. In leading states such as South Dakota, Delaware, and Illinois, the effect of abolishing the Rule is so profound that simple graphical depictions are highly suggestive. Second, in Sections B and C we present a formal econometric analysis that employs a standard difference-in-difference regression methodology that controls for contemporaneous changes in state law and relevant economic factors. Third, in Section D we offer a nontechnical synthesis of our findings. Readers interested in our results, but not in the formal methodology, will find Sections A and D of principal interest.

\section{A. Initial Data Analysis}

Figure 1 presents reported trust assets and average account sizes from 1985 to 2003 based on raw numbers and without an adjustment for inflation. Trust assets and average account sizes track each other closely, rising every year in a fairly smooth linear trend until 2000, followed by a sizeable dip in 2001, which may reflect stock market fluctuations. ${ }^{110}$

\section{[Insert figure 1 here]}

In the next five graphs we compare trends in reported trust assets in leading abolition states to each other, their neighboring states, and national averages. Because differences in population and local economies make graphical comparisons of total assets across states almost meaningless, in our comparisons we use trust assets per person or average account size. Dividing total assets by state population reduces the influence of population and highlights the success of small states such as Delaware and South Dakota. Dividing total assets by number of accounts (that is, average account size) likewise facilitates comparison across states. In addition, average account size is an

110. A cursory glance at this and the subsequent state level graphs suggests that in some states trust fund values are sensitive to fluctuations in public equities markets. We are in the process of testing this hypothesis as part of a separate empirical study of trust asset allocation. 
important variable in its own right for two reasons. First, average account size is less sensitive than total assets to the potential biasing effect of bank mergers and consolidations. Second, because the current exemption from the GST tax is $\$ 1.5$ million and for much of the period under study was $\$ 1$ million, an upswing in average account size above those figures implies not only an influx of trust assets but also that a fair amount of those assets are not transfer-tax exempt.

Figure 2 presents the trust assets per person in the important abolition states of Delaware and South Dakota in comparison to New York, a leading banking state, and to the national average. Delaware abolished the RAP in 1995, and South Dakota abolished the RAP in 1983, prior to the start of our data. As can be seen, South Dakota starts out with trust assets per person just below the national average at the beginning of the sample timeframe. By the mid-1990s, however, South Dakota's assets per person exceed the national average and equals or exceeds that of New York.

Having long been a trust-friendly jurisdiction, ${ }^{111}$ Delaware's assets per person begin at a very high level with an unexplained blip in 1991 and 1992, prior to abolition, then experience a strong upward trend in the mid-1990s, roughly coinciding with Delaware's abolition of the RAP. We have no good explanation for the 1991-1992 blip. Given Delaware's otherwise smooth upward trend, we could interpolate the data for 1991 and 1992. However, this unexplained increase in trust assets occurs prior to Delaware's abolition of the RAP. As such, if included in our analysis, it would tend to bias our estimate of the effect of abolishing the Rule downward, working against a positive finding. For this reason, we have chosen the more conservative approach of accepting the data as reported by the FDIC.

\section{[Insert figure 2 here]}

In the next few graphs we compare average account sizes in Delaware, South Dakota, and Illinois (another important abolition state $^{112}$ ) to their neighboring states. We do so for illustrative purposes only. All states, not just those that are geographically proximate to abolishing states, are included in the formal econometric analysis.

111. See supra note 61 .

112. Illinois banks and lawyers have been particularly effective at securing law reform. For example, Illinois was one of the first states to revise its trust investment law in light of modern portfolio theory, see John H. Langbein, The Uniform Prudent Investor Act and the Future of Trust Investing, 81 IOWA L. REV. 641, 641-42 (1996), and Illinois statutory law makes the preparation of an inter vivos trust by anyone other than a lawyer or institutional trustee unlawful. 815 ILL. CoMP. STAT. $\S 505 / 2 \mathrm{BB}$ (1999). 
We begin in Figure 3 with a comparison of Delaware to Maryland, Pennsylvania, and New York. Delaware and New York start out with similar average account sizes, but Delaware rapidly outpaces New York in the mid-1990s, roughly coincident with the abolition of the RAP in Delaware. Neither Pennsylvania nor Maryland are in the same league as Delaware. Even after the precipitous drop in average account size in Delaware after the stock market decline of the early 2000 s, Delaware's average trust account size at the end of our sample timeframe is about double that in Pennsylvania and Maryland. Although Maryland abolished the Rule in 1998, since 1988 it has levied a fiduciary income tax on trust funds attracted from out of state. We posit that aversion to this tax explains Maryland's inability to compete with Delaware. The econometric analysis below supports this hypothesis.

\section{[Insert figure 3 here]}

South Dakota, which we examine in Figure 4, presents a clearer picture. In the mid-1980s, South Dakota's average account size was slightly larger than North Dakota's and Iowa's. The gap between the states begins to grow after 1987, with the implementation of the GST tax, and increases notably in the mid-1990s. This latter increase coincides with the abolition of the RAP in Delaware and the subsequent nationwide movement to abolish the RAP. In addition, at about the same time the Governor of South Dakota formed a task force to study the South Dakota trust laws and to recommend reforms "to allow South Dakota to continue its position as a highly desirable jurisdiction in which to locate trusts." 113

\section{[Insert figure 4 here]}

Illinois, which we examine in Figure 5, abolished the RAP in 1998. Average account size in Illinois increased by roughly $70 \%$ two years later, from $\$ 1.4$ million to nearly $\$ 2.5$ million. This increased average account size remained stable even in the face of the stock market decline of the early 2000s (which is consistent with a continued influx of assets). Chicago is a significant banking center and home to the prominent Northern Trust Company. ${ }^{114}$

113. Michael J. Myers \& Rollyn H. Samp, South Dakota Trust Amendments and Economic Development: The Tort of "Negligent Trust Situs" at Its Incipient Stage?, 44 S.D. L. REV. 662, 664 (1999).

114 . Because of the large and relatively immediate of effect of abolition on average account size in Illinois, the reader may be concerned that our results are driven entirely by Illinois. However, as illustrated by Figure 6, infra, the swift in- 


\section{[Insert figure 5 here]}

Interestingly, Wisconsin, which abolished the RAP long before the introduction of the GST tax, appears to have been unable to compete with Illinois. As in the case of Delaware and Maryland, we posit that the disparity between Illinois and Wisconsin is a result of their different FIT rules. During the period under study, Illinois did not tax income in trust funds attracted from out of state, but for most years Wisconsin did. The econometric analysis below supports this hypothesis.

Another interesting implication of this graph is that after Illinois abolished the RAP its trust institutions experienced an influx of large trusts that were probably not wholly transfer-tax-exempt. The exemption from the GST and estate taxes is currently $\$ 1.5$ million and for most of the period under study was $\$ 1$ million. Yet average account size in Illinois rose quickly from less than $\$ 1.5$ million to about $\$ 2.5$ million after the RAP was abolished. The implication is that a fair number of the new accounts were worth more than $\$ 1.5$ million. To the extent that the initial funding of such trusts exceeded $\$ 1$ or $\$ 1.5$ million, the excess is subject to federal wealth transfer taxes. In a similar vein, observe that Delaware, like Illinois, experienced a rapid increase in its average account size, which at the time Delaware abolished the RAP already exceeded the exemption amount (see Figure 3 above and Figure 6 below).

We conjecture that the inflow of very large accounts reflects the administrative efficiencies of locating all of one's trust assets in a single account with one institutional trustee. Under typical fee schedules, larger accounts pay a smaller percentage in fees relative to smaller accounts, ${ }^{115}$ and professional fiduciaries are willing to negotiate even lower fees for (and to give more personal service to) larger

crease in Illinois merely brought Illinois up from the national average to an average account size comparable with that of New York and Delaware. Further, in unreported regressions, we find that our estimate of the effect of abolition excluding Illinois remains statistically significant, albeit somewhat less so.

115. The June 2004 fee schedule for the Chicago-based Northern Trust Company is as follows: a minimum annual fee of $\$ 12,500$ for any size trust up to $\$ 1$ million, plus $0.80 \%$ for the next $\$ 2$ million; $0.70 \%$ for the next $\$ 2$ million; $0.50 \%$ for the next $\$ 5$ million; $0.45 \%$ for the next $\$ 5$ million; $0.45 \%$ for the next $\$ 15$ million; and $0.40 \%$ for the next $\$ 25$ million. NORTHERN TRUST COMPANY SCHEDULE OF FEES (on file with the YALE LAW JOURNAL). Under this schedule the annual fee for a $\$ 3$ million trust would be $\$ 28,500$ and for a $\$ 10$ million trust would be $\$ 67,500$. The prominent Wilmington Trust Company, located in Delaware, has similar published rates: a minimum annual fee of $\$ 10,000$ for any size trust up to $\$ 1$ million, plus $1 \%$ of the next $\$ 1$ million; $0.75 \%$ for the next $\$ 3$ million; $0.50 \%$ for the next $\$ 5$ million; and $0.35 \%$ for the next $\$ 10$ million. WILMINGTON TRUST COMPANY SCHEDULE OF FEES (on file with the YALE LAW JOURNAL). 
accounts. ${ }^{116}$ On this view the availability of perpetual transfer-taxexempt trusts provides an opening to attract all of the donor's trust business.

In Figure 6 we compare average account sizes in Delaware, Illinois, New York, South Dakota, and the national average. Many of the trends remarked above are again discernable. The trend in average trust account size in Delaware roughly tracks that of New York until Delaware abolished the RAP in 1995, whereupon Delaware outpaces New York in all subsequent years. Average account size in South Dakota, which had abolished the RAP prior to the enactment of the GST tax, trails the national average until the mid-1990s. By 1998, when Illinois abolished its RAP, South Dakota catches up to the national average. Average account size in Illinois, which prior to 1998 more or less tracks the national average, breaks away and substantially outpaces it from that point forward, catching up with New York in 2000 and Delaware in 2002.

\section{[Insert Figure 6 here.]}

In our view, the foregoing graphs support the hypothesis that those states that abolished the RAP and did not tax income in trusts attracted from out of state experienced a significant inflow of large trust funds upon abolishing the Rule. This hypothesis is borne out in the econometric analysis below.

These data also suggest that the abolition of the Rule Against Perpetuities prior to the introduction of the GST tax had no observable effect on a state's trust assets. Recall that Wisconsin (1969), Idaho (1957), and South Dakota (1983) abolished the RAP by statute prior to the 1986 enactment of the GST tax, and that throughout this period South Dakota did not have a FIT. ${ }^{117}$ Yet in 1985 and 1986, the two years prior to the GST tax that are included in our sample timeframe, the average account size in each of these states closely matched those of their neighboring states and trailed the national average.

Let us examine the numbers directly. In 1985 and 1986, the abolition states had average account sizes between $35 \%$ and $50 \%$ below

116. See Robert Frank, Rich, Richer, Richest: Private Banks' Class System, Wall ST. J., Sept. 8, 2004, at D; see also WilmingTON TRUST COMPANY SCHEDULE OF FEES, supra note 105 (indicating that fees on accounts in excess of \$20 million are individually negotiated) (on file with the YALE LAW JOURNAL).

117. By judicial decision Wisconsin may have abolished its Rule even earlier. See W. Barton Leach, Perpetuities: The Nutshell Revisited, 78 HARV. L. REV. 973, 974-75 (1965). We need not resolve whether it did so, however, because our data does not begin until 1985, well after Wisconsin's statutory repeal. 
the national average, with little difference between them and their surrounding states. In the case of Wisconsin, average account size in 1985 and 1986 was below that of surrounding states. In South Dakota, average account size in 1985 and 1986 was slightly ahead of North Dakota and Iowa. In Idaho, which is not graphed above, average account size was $\$ 224,000$ in 1985 and $\$ 211,000$ in 1986, comparable to its neighbor Montana, which had average trust sizes of $\$ 180,000$ in 1985 and $\$ 220,000$ in 1986 .

The early abolition states also had average account sizes much smaller than the national average in 1985 and 1986. In 1985 the average account size nationally was $\$ 393,000$, while average account sizes in Idaho, South Dakota, and Wisconsin were \$224,000, $\$ 228,000$, and $\$ 257,000$ respectively. In 1986 , the figures were $\$ 448,000$ nationally, and $\$ 211,000, \$ 237,000$, and $\$ 275,000$, respectively, in Idaho, South Dakota, and Wisconsin. Similar results obtain if we consider trust assets per person. There is little evidence, therefore, that people valued perpetual trusts prior to the GST tax. ${ }^{118}$ As an initial matter, we infer that without the GST tax incentive to act as a wedge, few individuals would establish perpetual trusts. Further, our analysis of the data from 1969 through 1984, which we present in a forthcoming study, strongly support this conclusion. ${ }^{119}$

\section{A. The Estimation Strategy}

We estimate the effect of abolishing the RAP using four different dependent variables and several model specifications. We examine the effect of the abolition of the rule on total trust assets (Table 1), log trust assets (Table 2), average account size (Table 3), and total number of accounts (Table 4). We also consider trust assets per person in Appendix B.

The most straightforward specification is a simple before-andafter comparison using a dummy variable equaling one after a state abolishes the RAP and zero otherwise. This specification takes the form:

118. For this reason, we do not code the RAP as abolished in South Dakota, Idaho, or Wisconsin prior to the introduction GST tax. Technically, we should code these states as abolition states prior to 1987 and then interact the effect of the GST tax with the abolition dummy. However, this would leave only six identifying observations in the main effect. In addition, there were no statistically significant differences between these and other states in trust assets, average account size, or assets per person prior to 1987 , which leads us to conclude that the effect of the abolition of the RAP is driven by the GST tax. The results differ little in either case, but are slightly more significant if we code all pre-GST years as non-abolition years.

119. See Schanzenbach \& Sitkoff, supra note 12. 
[Vol. nn:nnn

\section{[Insert equation 1 here]}

where $\mathrm{j}$ indexes state and $\mathrm{t}$ indexes time. The variable Abolish equals one beginning the year after a state abolishes the RAP. The coefficient $\eta$ gives a simple before-after comparison of the effect of abolition. Some states abolished the RAP early in the year, others did so late in the year. Given the reality that it takes time to draft new trust forms and for clients to execute them, we begin counting a state as having abolished the RAP in the first year after the year of abolition. (The results when we included the year of abolition were slightly weaker, but little-changed.) Year represents a matrix of year dummies, which remove the effects of market fluctuations, inflation, and economic growth. State represents a matrix of state dummies, which remove state average differences. Therefore, every model conditions on state fixed-effects, which means that changes are measured relative to the state average. All models include state and year dummies.

The simple difference-in-differences specification described above is open to a few potential biases. The states that abolish the Rule may be the states that are most responsive to the demands of local banks and trust lawyers. Hence, these states may have adopted other reforms simultaneously. To account for this possibility, we add controls for two other important margins in the jurisdictional competition for trust funds: (1) the recognition of APTs, and (2) whether a state levies an income tax on trust funds attracted from out of state. In the hope of throwing light on the Waggoner/Dukeminier debate over USRAP, we also (3) add a control for whether a state has adopted USRAP. ${ }^{120}$

Further, we account for two more factors that may lead to state differences: population and individual income. Larger and wealthier populations will tend to have more and larger trusts. Hence, we add yearly census estimates to control for state population and, as a proxy for wealth, yearly estimated state-aggregate personal income.

Another concern is that secular trends in states that abolished the RAP might be driving any positive findings. ${ }^{121}$ We therefore include state-specific linear time trends in some specifications. Yet another way to test for biasing trends is to include dummy variables for the

120. Because of the merger and branching issues discussed above, the coefficient estimates on these controls may be biased when aggregate trust assets and accounts are considered and should be interpreted cautiously. For the reasons detailed earlier, we are more confident of the results when we consider average account sizes.

121. By "secular trends," we mean general time trends that are not explained by any of the available independent variables. 
years prior to the abolition of the RAP. In some specifications we include dummies for two years prior to abolition, the year before the abolition, and the year of the abolition.

In Specification 1 and its variants, we code Abolish as a dummy variable, which would accurately reflect the effect of abolition only if abolition results in an immediate and discrete jump in assets. Hence Specification 1 imposes a strong functional form on the effect of abolishing the RAP, which may be ill-suited to the phenomenon for at least two reasons. First, for the bar to digest the change in the law and to sell the new product to clients takes time. The GST tax and the Rule Against Perpetuities are complex, and the interaction of the two was not immediately obvious.

Second, because existing trusts in non-abolition states are drafted to comply with the Rule, ${ }^{122}$ and because moving a trust often requires judicial approval, the phenomenon is probably driven by new trust funds rather than the movement of existing trusts. If so, the effect of abolition will be gradual as new trusts are created and accumulate. Specification 1, however, assumes a perfectly liquid market in trust funds with no transaction costs and no agency costs between lawyers and clients. ${ }^{123}$

A further problem with the assumptions underpinning Specification 1 is that as additional states abolished the RAP in the mid-1990s, the competition for trust business became fiercer. With an increasing number of perpetual trust jurisdictions, the payoff to abolition might well shrink (eventually the payoff might be more in the nature of retaining assets than attracting them ${ }^{124}$ ). If so, the effect of abolition may decrease over time. With these factors in mind, we allow the effect of reform to increase and decrease over time by entering a quadratic term for reform as follows:

\section{[Insert equation 2 here]}

As discussed earlier, not all states levy an income tax on trust funds attracted from out of state. While the tax burden varies within a taxing state because of increasing marginal rates, we think a dummy variable specification for FIT as YES or NO, as defined earlier, is sufficient. First, controlling for increasing marginal rates, particularly

122. See Sterk, supra note 32 , at 2117 n.81.

123. Cf. Myers \& Samp, supra note 113, at 671-79 (assessing the possibility of attorney liability for negligent trust situs).

124. Noting that "[o]ther states have enacted similar measures," the staff of the Arizona Senate explained that Arizona's perpetual trust legislation (ARIZ. STAT. § 14-2901) was "an effort to retain people who want to set up [perpetual trusts] in state.” FACt SHEET FOR S.B. 1112., S. 112, 47th Leg., Reg. Session (Az. 1998). 
where, as here, we do not observe individual accounts, is not feasible. Moreover, many states do not levy a FIT on trust funds attracted from out of state (these states are coded as NO for FIT in Table 5). Once the settlor decides to incur the costs of settling a trust out-of-state, the marginal cost of choosing a state that will not levy a FIT on the trust's income is close to zero. Hence, our binary coding scheme is likely to comport with actual practice.

Fortunately for our estimation strategy, there are RAP states and abolition states that do not tax, and a handful of states changed their tax treatment of trust funds attracted from out of state during our sample time period. (One abolition state changed its tax status: Wisconsin switched to NO for FIT in 1999. Florida abolished the RAP and its tax at the same time in 2001.) Thus, we estimate the following model, interacting tax status with the abolition dummy:

\section{[Insert equation 3 here]}

In Specification 3 the primary coefficient of interest is $\beta$, which measures the marginal impact of eliminating both non-resident trust taxes and the RAP. We also report a specification interacting the NoFIT variable with the quadratic term.

The data used are state-level panel data. The specification strategy used state fixed effects to deal with state error terms. Randomeffects models were also employed, and yielded surprisingly similar coefficient estimates and standard errors. In practice, fixed effects are favored for state panels such as this, so we report those results. In addition, we ran feasible generalized least squares regressions allowing for panel-specific autocorrelation. The results for the interaction effects (which we believe to be the correct specification) survived largely intact. Accordingly, all reported regressions are OLS and include a constant term, state dummies, and year dummies.

Because APTs were adopted in only a few states, all toward the end of the sample timeframe, we have few observations on them. Further, in the period under study, Nevada was the only state that both retained the Rule Against Perpetuities and adopted APTs, having authorized them in 1999. Therefore, in one specification we exclude the three joint abolition/APT states (Delaware, Alaska, and Rhode Island) from the estimation entirely to confirm that our results are driven by the abolition of the RAP, not by APTs. In these specifications, we also exclude Massachusetts because of the merger event discussed above. 


\section{Econometric Results}

We examine several different measures of a state's competitiveness in trust assets: total assets (Table 1), log total assets (Table 2), average account size (Table 3), and number of accounts (Table 4).

\section{1. $\quad$ Trust Assets (Tables 1 and 2)}

The regressions reported in Table 1 use total reported assets as the dependent variable. Model 1 estimates Specification 1, which is the effect of abolition conditioned only on year and state fixed effects. The coefficient estimate on Abolish is 6.63 and is significant at the 5\% level, implying that after a state abolished the RAP, it attracted $\$ 6.63$ billion more in reported trust assets relative to states that did not abolish the RAP. To put this finding in perspective, the average state had $\$ 19$ billion in reported trust assets in 2003. Given that smaller states such as Alaska, South Dakota, Wisconsin, and Idaho were among the first to abolish the RAP, this result is even larger than a comparison to the overall state average implies.

Model 2 adds some additional dependent variables, and the coefficient on Abolish decreases slightly to 6.02. None of the trust law variables-APTs, USRAP, or FIT - are significant at the 5\% level. While state income is significant and signed positively as expected, the effect of state population is surprisingly negative and significant, implying that increases in population decrease relative trust assets. We suspect, however, that this result is nothing more than an artifact of how strong the competition for trust assets has been from the small states. Delaware, South Dakota, and Alaska, which are among the most aggressive of the abolishing jurisdictions, have small populations.

Model 3 includes dummy variables for the year of abolition and for each of the prior two years. No strong trends are discernable. In Model 4, which adds state-specific trends, the coefficient on Abolish decreases to 3.97 , but remains statistically significant at the 5\% level. Finally, the exclusion of Alaska, Delaware, Massachusetts, and Rhode Island in Model 5 makes little difference to the coefficient estimate, though now the result is barely significant at the 5\% level.

In sum, our simple before-after specification suggests that state trust assets significantly increased after the abolition of the RAP, and this result is robust to the inclusion of time trends and the exclusion of asset-protection states. Taking the coefficient as correct, a back-ofthe-envelope calculation of the total trust assets attracted by abolishing the RAP is striking. Within the timeframe of our sample 16 states 
abolished the RAP with a resulting average increase of roughly $\$ 6$ billion in trust assets per state. This implies that as of 2003, roughly $\$ 100$ billion in trust funds have poured into the states that have abolished the Rule ( $\$ 6$ billion per state $\times 17$ states $=\$ 102$ billion in total assets).

We must emphasize, however, that this $\$ 100$ billion figure is a rough estimate given the standard errors. ${ }^{125}$ Further, we we cannot discern the extent to which the observed increase in trust assets reflects an inflow of newly created trusts or the poaching of already existing trusts. On the other hand, because our sample includes only of trusts administered by federally-reporting institutions, our estimates probably understate the total increase in trust assets experienced by the abolishing states. Likewise, the quadratic models imply that these are underestimates because the effect grows over time (at least for the first ten years or so), but the Abolish coefficient is simply the average effect by state, most of which abolished the RAP in the late 1990s.

We now turn to the effect of FITs. Model 6 allows an interaction between NoFIT and Abolish. Here the coefficient on Abolish is indistinguishable from zero, while the coefficient on the interaction term NoFIT*Abolish is 14, roughly twice as large as the effect of Abolish before. We interpret these coefficients to imply that a state that abolished the Rule, but taxed income in trust funds attracted from out of state, experienced no observable increase in trust business. By contrast, a state that abolished the Rule and did not tax income in such trusts experienced an average increase in reported trust assets of $\$ 14$ billion. This finding strongly implies that the increases we observe stem from the inflow of assets from out of state. (In principal, the NoFIT*Abolish coefficient of 14 should be weighed against the seemingly anomalous negative coefficient on NoFIT. We discuss this qualification in greater detail below.)

The quadratic specification in Model 7, which tests jointly significant at the 0.032 level and so appears to fit the data well, yields some very interesting results. The coefficient on Years Abolished is positive, and the squared term is negative, suggesting an effect that

125. The $95 \%$ confidence interval implies that between $\$ 11$ billion and $\$ 200$ billion poured into the abolishing states (i.e., there is a $95 \%$ chance that the true point estimate lies somewhere within this range). We could also calculate this figure using the coefficients given in Model 6. Ten states (counting Wisconsin) abolished the Rule and did not tax trust funds attracted from out of state. If we ignore the coefficients on Abolish and NoFIT, we have $\$ 14$ billion per state $\times 10$ states $=$ $\$ 140$ billion (and a 95\% confidence interval between $\$ 50$ billion and $\$ 220$ billion). If we subtract off the negative NoFIT coefficient (-6.5) we have $\$ 7.5$ billion per state $\times 10$ states $=\$ 75$ billion. The NoFIT result is significant at the .039 level and disappears in other specifications, so it is not clear how to treat it for these purposes. 
increases and then decreases over time.Taking the coefficients at face value, a state increases its trust assets each year after the abolition of the RAP, peaking roughly 10 years after abolition. This result is consistent with our learning hypothesis. The fact that the effect of abolition eventually slows is consistent with increased competition as more states abolished the RAP in the late 1990s and early 2000s. ${ }^{126}$ When the quadratic is interacted with NoFIT in Model 8, the results again indicate that nearly all of the observable effect of abolition emanates from abolition states that do not levy an income tax on trust funds attracted from out of state.

As a robustness check, we replicate some of these regressions in Table 2 using log trust assets as the dependent variable. The effect of using log trust assets is two-fold. First, it reduces the influence of outlier states with large trust assets, such as New York and Delaware. Second, the coefficient on Abolish is now interpreted as the proportion increase in trust assets after abolition (e.g., a coefficient of .25 on Abolish would imply trust funds increased by $25 \%$ after abolition).

In the first three models, the results on our variables of interest are remarkably similar to Table 1 and imply that trust assets increase by roughly $20 \%$ after a state abolishes the Rule. In the quadratic specification in Model 5, the coefficients are not jointly significant, although the terms are signed the same as in Table 1 with roughly the same relative magnitude. However, when the NoFIT interactions are added to the quadratic specification, the results are strongly significant and comparable to those in Table 1. This finding again suggests that abolition mainly increases the trust assets of those states that also did not levy an income tax on trust funds attracted from out of state.

There are two somewhat anomalous findings we wish to address. First, the USRAP results in both Tables 1 and 2 are positive and sometimes statistically significant at the $5 \%$ level or close to it. Second, in both tables the NoFIT dummy is negative and significant when it is interacted with Abolish.

In our view, the weak USRAP results in Tables 1 and 2 do not provide sufficient grounds to conclude that adoption of USRAP had an effect on a state's trust assets. First, the USRAP results in Tables 1 and 2 are not replicated in the other regressions. Second, when we take $\log$ trust assets as our dependent variable in Table 2, the USRAP coefficient is significant only in Model 4.

Third, the coefficients become very small and insignificant in both Tables 1 and 2 when state-specific trends are entered (this result recurs when we take the number of accounts as our dependent vari-

126. As previously noted, stock market effects and other yearly fluctuations are removed by the inclusion of year dummies. 
able in Table 4). That the USRAP results are positive without statespecific trends, but disappear with state-specific trends, is consistent with the hypothesis that states that adopted USRAP had contemporaneously growing trust business. States with growing trust business are likely to have an organized trust bar, and prior to the repeal movement USRAP was popular with trust lawyers. ${ }^{127}$

Fourth, we are not as confident with respect to USRAP as we are with respect to abolition that our methodology has removed the potentially biasing effects of bank mergers. The USRAP coefficient is never statistically significant when we consider average account size in Table 3, which is the dependent variable least affected by mergers. Further, when we take trust assets per state resident as our dependent variable in Appendix Table 1, the USRAP results are at times negative and significant.

In sum, our USRAP results allow us to conclude only that the data do not support the proposition that enactment of USRAP leads to an increase in the state's reported trust assets.

We turn now to the negative NoFIT results. The coefficient on NoFIT is only negative and significant when we interact NoFIT and Abolish. Technically, one should add all three coefficients (NoFIT, Abolish, and Abolish*NoFIT) to get the full interactive effect of abolishing the RAP and not taxing income in trusts attracted from out of state. For example, in Model 6 of Table 1 the coefficient on Abolish is small (-0.98) and not significant, so we can ignore it. The NoFIT coefficient is -6.51 and significant at the 5\% level, implying that the full effect of abolishing the RAP and not taxing trust funds attracted from out of state is more on the order of $\$ 7.5$ billion, not $\$ 14$ billion. ${ }^{128}$ This result recurs in Table 2, but is even more pronounced. Importantly, however, these negative NoFIT coefficients do not alter our central conclusions that (1) abolishing the RAP increases the state's reported trust assets, and (2) all of the observable effect of abolition comes from states that also did not levy an income tax on trusts attracted from out of state. The key results are that the main effect of Abolish disappears and the interacted effect is large and significant.

The counterintuitive negative NoFIT coefficient probably results from specification error. First, the NoFIT coefficient was generally small and not statistically significant prior to the interaction. Second, the before-and-after comparisons impose some strong conditions on the data. Inasmuch as the more flexible quadratic specifications strongly suggest that the effect of abolition decayed over time, in our

127. See DUKEMINIER \& JOHANSON, supra note 33 , at 836.

128. See supra note 125 and text accompanying. 
simple interaction we may be forcing the negative result into the tax term. Notice that the significant, negative tax result goes away in the quadratic interaction in both Tables 1 and 2. Third, the NoFIT coefficient is never significant when we take average account size to be the dependent variable in Table 3. Finally, only five states changed their tax policies. As a result, we do not have much identifying information on NoFIT, so it is not surprising that the coefficient on NoFIT is sensitive to model specifications. ${ }^{129}$

\section{Average Account Size (Table 3)}

Average account size is an important dependent variable for a number of reasons. First, as noted above, average account size should be less sensitive to the potential bias from mergers and branching. Second, the exemption from the transfer taxes is today $\$ 1.5$ million and for much of the period under study was $\$ 1$ million. Hence, an increase in average account size above those numbers implies an influx of trust assets that are not exempt from transfer taxation. Third, there are economies to locating all of one's trust assets in a single account with one institutional trustee because larger accounts pay a smaller percentage in fees relative to smaller accounts and substantial clients get better service. ${ }^{130}$ Thus, there is reason to suspect that banks and trust companies lobbied for the abolition of the RAP as a gateway to attract all the trust business of wealthy settlors.

The results for average account size, which track the abolition results for total trust assets (Table 1), are reported in Table $3 .{ }^{131}$ In the simple specification of Model 1, abolition of the rule raises average account size by $\$ 289,000$. To put this figure in perspective, the average account size in 2003 was about $\$ 1$ million. The effect of abolition decreases to $\$ 191,000$ when we include more control variables in Model 2, probably because APTs are found to have a large effect (roughly $\$ 507,000$ ) and, of the four APT states, three also abolished the RAP. Not surprisingly, the joint significance of the two taken together is very strong (roughly the 0.0001 level) in Models 2 and 3. However, the estimated effect of APTs is negative (but not significant) when we include state-specific trends in Model 4, and when we exclude the primary APT states in Model 5, the effect of abolition remains significant but decreases to $\$ 150,000$. Accordingly, the ef-

129. Because we include state fixed-effects in every model, we can identify policy effects only from those states that changed policies in the timeframe of the data.

130. See supra notes $115-116$ and accompanying text.

131. Note that, because we are using average trust size, we use state income per capita as the dependent variable instead of gross income and population. 
fect of abolition is clear and consistent across models, while the effect of validating APTs is not consistent. ${ }^{132}$

The interaction between Abolish and NoFIT in Model 6 suggests, consistent with our previous results, that most of the effect on account size comes from abolition states that do not levy a tax on income in trusts attracted from out of state. The quadratic specification of Model 7 suggests an increasing but decaying effect over time, but is not jointly significant. However, interaction of the quadratic term with NoFIT yields coefficients that are jointly significant at less than the .0001 level, ${ }^{133}$ and these coefficients are consistent with our previous findings. Specifically, the interaction results imply an increasing-then-decreasing growth in average account size in those states that abolished the RAP and do not levy an income tax on trust funds attracted from out of state.

In sum, average account size increases by nearly $\$ 200,000$ after the RAP is abolished, and this effect comes almost entirely from states that did not tax income in trusts attracted from out of state. As before, the quadratic specification suggests that the effect of abolishing the Rule initially increases trust assets but then the effect wanes. Thus, our results for aggregate trust assets are largely replicated for average account size.

\section{Total Number of Accounts (Table 4)}

Table 4 reports the results of regressions that use total reported state accounts as the dependent variable. In this case, the dummy variable specifications yield insignificant results and small coefficient estimates. However, the quadratic term in Model 5 is jointly significant and signed as before. Though neither the linear nor the squared term is independently significant, their joint significance of 0.0423 implies that there was an increase in the number of accounts after a state abolished the RAP. Taking the coefficients at face value, the first year a state abolishes the RAP it draws nearly 700 additional accounts relative to non-abolition states. Five years after a state abolishes the RAP, it has drawn nearly 2,000 additional accounts.

The tax interactions are mixed. In Model 3, the interaction term is positive but not statistically significant at the $5 \%$ level. The quadratic interaction in Model 6 is difficult to interpret as well. Taking the co-

132. The results for total assets suggest the same conclusion. In Table 1 the APT coefficient, which was positive (but not significant) in Model 2, became negative and significant when we added state-specific trends in Model 4.

133. Indeed, although not report in the table, the quadratic interaction terms are jointly statistically significant at the 0.0001 level independent of the main effects. 
efficients at face value, accounts decrease and then increase in states that abolish the RAP, but this effect is reversed in states that abolish the RAP and do not tax. The results are strongly jointly significant ( $p$-value is 0.0001), however, and the coefficients suggest that accounts grew at an increasing rate after abolition. It is also clear that the largest effect again emanates from states that both abolished the RAP and do not levy an income tax on trust funds attracted from out of state. The dummy variable specification (which represents the average effect over time) suggests a small effect. This implies that even if the strongly significant quadratic specification is valid, the net effect has been quite small.

The small effect of abolition on total accounts fits neatly with our trust-asset and average-account findings: If trust assets increased by proportionately more than trust accounts in abolition states, then abolition must be attracting relatively larger accounts. Our findings for average account size indicate this to be the case. ${ }^{134}$

\section{Summary of Results}

In this Section we offer a nontechnical summary of our principal findings.

\section{Perpetuities and Fiduciary Income Taxes}

We find that after a state abolished the Rule Against Perpetuities, its reported trust assets through 2003 increased by as much as $20 \%$ relative to states that retained the Rule. This finding is replicated for average account size, which likewise increased by as much as $20 \%$ relative to states that retained the Rule. In dollars, after a state abolished the Rule, its reported trust assets increased through 2003 by roughly $\$ 6$ billion relative to those that retained the Rule. Average account size increased by roughly $\$ 200,000$. These results are replicated in regressions that exclude Delaware and Alaska, which tells us that the phenomenon is not limited to those two states.

Regarding fiduciary income taxes, we found that, by itself, whether a state levies an income tax on trust funds attracted from out of state had no observable effect on the state's reported trust assets. This finding is consistent with the incentives created by the federal income tax. For many trusts the process of avoiding the federal in-

134. These results also imply that mergers are not confounding our results. If increases in reported assets in abolition states were driven by the acquisition of banks in non-abolition states, we would expect to observe a proportionate increase in the number of reported accounts. 
come tax likewise avoids state income taxes. ${ }^{135}$

Perpetual trusts, however, have a different duration and purpose from ordinary trusts that might warrant accumulating trust income. Although doing so unavoidably triggers federal income tax liability, state income tax liability can be avoided by locating the trust in a state that does not levy a FIT on trust funds attracted from out of state. Accordingly, we predicted that the effect of abolishing the Rule would be magnified in states that did not tax income in trust funds attracted from out of state. ${ }^{136}$

To assess this prediction, we tested the interactive effect of a state's income tax and perpetuities laws. These tests indicate that only those states that did not tax income in trusts attracted from out of state experienced an inflow of trust assets after abolishing the Rule. States that abolished the Rule but taxed such trusts experienced no observable increase in reported trust assets. These findings are consistent with our theoretical intuitions. Once a settlor has committed to incurring the costs of establishing an out-of-state perpetual trust, the marginal cost of choosing a state that does not tax trusts attracted from out-of-state is close to zero but the benefits are potentially great.

We conclude that the effect of abolishing the Rule is substantial. Our findings imply that, through 2003, roughly $\$ 100$ billion in trust funds have poured into the states that have validated perpetual trusts. ${ }^{137}$ Assuming the applicability of typical industry commission schedules, these funds are worth perhaps as much as $\$ 1$ billion in yearly trustees' commissions. ${ }^{138}$

We hasten to add three caveats. First, we cannot estimate the tax revenue lost owing to the use of perpetual transfer-tax-exempt trusts. Such an estimate would require complex actuarial discounting based on individual account data, but we have only state-level data. The most we can say is that not all the trust dollars that have poured into the abolishing states are transfer-tax exempt. After abolishing the Rule, average account size in Illinois and Delaware both increased

135. See supra Subsection I.D.2.

136. See id.

137. See supra note 125 and accompanying text.

138. For typical commission schedules, see supra note 115 . The $\$ 1$ billion figure is a very rough estimate that assumes a typical account size between $\$ 1$ million and \$2 million. Because the data implies that a fair number of much larger trusts moved into the abolition states, see supra text accompanying note 115 , and larger trusts pay a smaller percentage in fees, there is good reason to suppose that this estimate overstates the true figure. On the other hand, because our sample of federally-reporting institutional trustees does not include the entire population of trust funds, our estimates probably understate the total increase in trust assets experienced by the abolishing states. 
and exceeded the transfer-tax exemption. ${ }^{139}$

Second, we cannot discern the extent to which any given state's increase in reported trust assets stemmed from an inflow of newlycreated trusts versus the poaching of already-existing trusts. ${ }^{140}$ Likewise, to the extent that our findings represent the movement of already-existing trusts, we cannot identify from which states those trusts moved.

Third, because our sample data is limited to federally-reporting trustees (and so does not include the entire trust fund population), our estimates likely understate the amount of trust assets that have moved as a result of the movement to abolish the Rule.

\section{Self-Settled Asset Protection Trusts}

There is some tentative evidence that validating APTs increases a state's trust business. We did not consistently find this effect, however, and our findings are highly sensitive to choice of control variables and regression model. In technical terms, the relevant coefficient was not consistently signed and in many specifications was not statistically significant. Accordingly, we can neither confirm nor deny the existence of a significant APT business. The most we can say is that, through 2003, the effect on a state's trust business of validating APTs is not on the same order of magnitude as the effect of abolishing the Rule Against Perpetuities. We intend to revisit this question soon when more data is available. After the period of our study, two more states and possibly a third validated APTs. ${ }^{141}$

\section{Uniform Statutory Rule Against Perpetuities}

We find no consistent evidence that adopting USRAP increases a state's trust business.

\section{IMPLiCATIONS FOR POLICY DEBATES}

\section{A. The Fall of the Rule Against Perpetuities}

The jurisdictional competition for trust funds is both real and intense. At the behest of local banks and lawyers, since 1986 a third of

139. See supra Section III.A.

140. Because already-existing trusts in jurisdictions that retained the Rule would have been drafted to comply with the Rule, see Sterk, supra note 32, at 2117 n.81, we conjecture that our results arise primarily from new trusts.

\section{See supra note 81 and accompanying text.}


the states have altered their laws to give their local banks and lawyers a competitive advantage in what our results show is a national market for trust fund services. Our estimates imply that, through 2003, the movement to abolish the Rule Against Perpetuities has affected the situs of $\$ 100$ billion in reported trust assets-roughly $10 \%$ of the 2003 total. $^{142}$ Not surprisingly, the trend toward abolition has accelerated in recent years.

There is, of course, a growing literature that examines the pros and cons of the fall of the Rule, ${ }^{143}$ an issue that is beyond the scope of this Essay. It is enough here to make three observations. First, the existing literature lacks a solid empirical foundation, a problem that plagues not just domestic scholars but students of the Rule throughout the common law world. Recall that in its recent report on perpetuities reform, the English Law Commission lamented the lack of empirical evidence (and the impossibility of obtaining any) on the Rule's effect. ${ }^{144}$ Accordingly, we hope that our findings will illuminate the policy debate, both domestically and abroad, by supplying an empirical analysis of the domestic movement to abolish the Rule. ${ }^{145}$ To that end, we discuss below a recent proposal by the staff of the Joint Committee on Taxation to close the perpetuities loophole in the GST tax. ${ }^{146}$ As we shall see, the staff based its analysis in part on an assumption that our findings show to be erroneous.

Second, much of the existing literature focuses on the evils of perpetual dead-hand control without discounting those evils in view of their likelihood. If a perpetual trust is drafted so that each generation is given a special power to appoint the remainder to the next generation outright or in further trust as in Case 3 above, ${ }^{147}$ dead-hand concerns

142. See supra note 125 and accompanying text.

143. See supra note 32.

144. See text accompanying supra note 10. The Law Commission did, however, conduct a survey of Scottish conveyancing lawyers to learn about the effects, if any, of there being no Rule Against Perpetuities in Scotland. See ENGLISH LAW COMM'N, supra note 10, at 21-22. Another example of perpetuities reform abroad comes from Canada, where the province of Manitoba abolished its Rule over twenty years ago. 1982-83-84 S. M. ch. 38, 43; see also DUKEMINIER ET AL., supra note 4, at 721, 723 (discussing perpetuities reform in Manitoba and England).

145. For example, to the extent that our findings imply that abolishing the Rule prior to the enactment of the GST tax had little effect on a state's trust business, they tend to support the proposals of Dukeminier and Krier, supra note 8, against the criticisms of Tate, supra note 32. On the other hand, the lack of perpetual trusts before the GST tax could stem from a lack of awareness of the possibility. Now that the GST tax has given perpetual trusts salience, prospective donors might remain interested in perpetual trusts even if Congress closes the perpetuities loophole in the GST tax. We discuss these issues further in Schanzenbach \& Sitkoff, supra note 12. For discussion of non-tax reasons to establish a perpetual trust such as protection from creditors, see Nenno, supra note 49 , at $\S \S 16,28$.

146. See JoInT COMM. ON TAXATION, supra note 13, at 392-95.

147. See supra text accompanying note 46 . Another possibility is the appoint- 
are resolved. Such a power permits each generation to decide whether to continue the trust (and its tax exemption) or to bring the trust to an end. We are told that such provisions are boilerplate in perpetual transfer-tax-exempt trust forms. ${ }^{148}$ On the other hand, even if these clauses become ubiquitous in the formbooks, they are not required, and trust lawyers have told us anecdotes about settlors who do not include these clauses because they seek precisely the perpetual control that the Rule was designed to prohibit.

Third, settlors who reside in a state that has retained the Rule can easily avoid the Rule by paying the small transaction cost required to create a trust in, and to move assets to, a state that has abolished the Rule. Hence, the federal transfer taxes have mortally wounded the once-formidable Rule by reducing it to a mere transaction cost. Of course, this is not the first time that federal tax law has warped state property law. ${ }^{149}$ But even if Congress were to close the perpetuities loophole in the GST tax, it is difficult to imagine the rise of an interest group that would lobby for reenactment of the Rule Against Perpetuities. ${ }^{150}$ Accordingly, to the extent that the policies that underpin the Rule continue to have contemporary relevance, it is necessary to look elsewhere to service those policies. ${ }^{151}$

\section{B. The Rise of the Self-Settled Asset Protection Trust?}

The jurisdictional competition in trust law appears ready to focus next on APTs. Indeed, in the last two years two more states and possibly a third have validated them. ${ }^{152}$ Because APTs could be used in

ment of a trust protector who is given the power to modify or terminate the trust and to name his or her successor. See RESTATEMENT (THIRD) OF TRUSTS $\S 64(2)$ (2003); DUKEMINIER ET AL., supra note 4, at 579-80. Modern texts urge the use of clauses that preserve flexibility, including the power to modify or terminate the trust. See, e.g., PENNELL, supra note 14, at 4-2 to 4-6; DUKEMINIER ET AL., supra note 4 , at 576 .

148. See, e.g., Nenno, supra note 49, at 164 (supplying a model clause); see also Pierce H. McDowell, III, The Dynasty Trust: Protective Armor for Generations to Come, TR. \& EST., Oct. 1993, at 47, 53 (noting that it "is often desirable to give at least some of the beneficiaries special testamentary powers of appointment that will enable them to change the dispositive terms of the trust" in light of unanticipated changes in circumstances).

149. See Ira Mark Bloom, How Federal Transfer Taxes Affect the Development of Property Law, 48 CLEV. ST. L. REV. 661 (2000); Robert T. Danforth, The Role of Federalism in Administering a National System of Taxation, 57 TAX LAW. 625 (2004); see also Dukeminier et al., supra note 4, at 428-29 (discussing the movement to adopt community property, which was stimulated in part by a quirk in the federal income tax).

150. This text glosses over the variety of means by which the states have authorized perpetual trusts. See supra note 68 and accompanying text.

151. See Schanzenbach \& Sitkoff, supra note 12.

152. See supra note 81 and accompanying text. 
effect to opt out of medical malpractice and almost any other form of liability, their validation has sparked a lively policy debate. ${ }^{153}$ This debate involves not only trust law but also touches on tort and bankruptcy reform. For example, the federal bankruptcy reforms adopted in April of $2005^{154}$ have been criticized by some for not also addressing APTs. ${ }^{155}$ Both before and after the 2005 legislation, an interest in trust that is not alienable under state law-which includes the settlor's interest in a domestic APT-does not become part of the bankruptcy estate. ${ }^{156}$

Unfortunately, as yet our data do not allow us to confirm or deny the existence of a significant domestic APT business, though we can say that, through 2003, the effect of validating APTs pales in comparison to the effect of validating perpetual trusts. As a theoretical matter, if domestic APTs become more popular, there is reason to suppose that a race to validate APTs will ensue. As we have seen in the case of the RAP, local banks and lawyers are adept at obtaining legislation to make them more competitive in the national market for trust business. Indeed, the current map of APT jurisdictions resembles the perpetual trust map circa 1995, just before Delaware and then a host of other states abolished the Rule. On the other hand, the existence of numerous offshore APT jurisdictions renders the analogy between APTs and the fall of the RAP imperfect. ${ }^{157}$ We intend to revisit this issue when we have more data.

153. There is a burgeoning academic literature on this question. See supra note 88. There is also a vast practitioner literature. See, e.g., Barry S. Engel \& David L. Lockwood, Domestic Asset Protection Trusts Contrasted with Foreign Trusts, 29 EsT. Plan. 288 (2002); Nenno, supra note 49, at $\S \S$ 69-115; David G. Shaftel, Domestic Asset Protection Trusts: Key Issues and Answers, 30 AM. C. TR. \& EsT. Couns. J. 10 (2004). This literature includes practice manuals. See, e.g., AM. BAR ASS'N, ASSET PROTECTION StRategies: PlanNING WITH DOMESTIC AND OFFSHORE ENTITIES (Alexander A. Bove, Jr., ed. 2002); DunCAN E. OSBORNE \& ELIZABETH MORGAN SCHURIG, ASSET PROTECTION: DOMESTIC AND INTERNATIONAL LAW AND TACTICS (2005). On creditor's rights in trust law generally, see Anne S. Emanuel, Spendthrift Trusts: It's Time to Codify the Compromise, 72 NEB. L. REV. 179 (1993); Adam J. Hirsch, Spendthrift Trusts and Public Policy: Economic and Cognitive perspectives, 73 WASH. U. L.Q. 1 (1995); see also Alan Newman, The Rights of Creditors of Beneficiaries Under the Uniform Trust Code: An Examination of the Compromise, 69 TENN. L. REV. 771 (2002) (examining creditor's rights under the Uniform Trust Code). 154. Bankruptcy Abuse Prevention and Consumer Protection Act of 2005, Pub. L. 109-8, 119 Stat. 23 (2005).

155. See Bankrupt Bankruptcy Bill, N.Y. TIMES, Mar. 3, 2005, at A30; Albert B. Crenshaw, Keeping Some Hiding Places, WASH. Post, Mar. 20, 2005, at F1; Gretchen Morgenson, Proposed Law on Bankruptcy Has Loophole, N.Y. TIMES, Mar. 2, 2005, at C1; see also David Shaftel \& David H. Bundy, Impact of New Bankruptcy Provision on Domestic Asset Protection Trusts, 32 EST. Plan. 28 (2005) (discussing criticism of the act and the act's relevance for domestic APTs).

156. 11 U.S.C. $\$ 541(c)(2)$ (2000). See Shaftel \& Bundy, supra note 155, at 3031; John E. Sullivan, New Rules, Old Game, TR. \& EsT., June 2005, at 59, 61.

157. Perhaps another difference is that APTs are more likely to face judicial challenge. See supra note 88 and accompanying text. 


\section{An Interest-Group Theory of Jurisdictional Competition}

Jurisdictional competition, sometimes also called regulatory competition, refers to the phenomenon of laws favorable to an industry being enacted to attract business to a jurisdiction. The idea, identified first by Charles Tiebout, is that people and firms "vote with their feet," moving from one jurisdiction to another based on changes in the local regulatory climate. ${ }^{158}$ Regulatory competition has been studied perhaps most notably in corporate law, ${ }^{159}$ but the phenomenon manifests itself in numerous other fields including securities, bankruptcy, environmental, secured transactions, welfare, and antitrust law, to name just a few. ${ }^{160}$

We have demonstrated that jurisdictional competition has influenced the situs of trust funds totaling roughly $\$ 100$ billion. More importantly, we can trace our results entirely to those states that did not levy an income tax on trust funds attracted from out of state. These findings have two important implications for the study of jurisdictional competition generally.

First, our findings lend support to public-choice theories of jurisdictional competition. ${ }^{161}$ Much of the literature on jurisdictional competition models states as if they were well-functioning, profitmaximizing firms. Hence it is commonly assumed that states seek to maximize tax and related revenues, which supplies the incentive to compete for business against other states. ${ }^{162}$ But as one of us has ar-

158. Charles M. Tiebout, A Pure Theory of Local Expenditures, 64 J. PoL. ECON. 416 (1956).

159. The classics are Ralph K. Winter, Jr., State Law, Shareholder Protection, and the Theory of the Corporation, 6 J. LEGAL STUD. 251 (1977); and William L. Cary, Federalism and Corporate Law: Reflections upon Delaware, 83 YALE L.J. 663 (1974). See generally, Sitkoff, supra note 17, at 1140-43 (summarizing the debate over regulatory competition in corporate law).

160. See, e.g., Marcus Cole, "Delaware is Not a State": Are We Witnessing Jurisdictional Competition in Bankruptcy?, 55 VAND. L. REV. 1845 (2002); Richard L. Revesz, Rehabilitating Interstate Competition: Rethinking the "Race-to-theBottom” Rationale for Federal Environmental Regulation, 67 N.Y.U. L. REV. 1210 (1992); Kahan \& Kamar, supra note 16, at 682-84 (collecting examples); see also Abraham Bell \& Gideon Parchomovsky, Of Federalism and Property Law, 115 YALE L.J. (forthcoming 2005) (proposing means to expand competition in state property law).

161. See, e.g., Carney, supra note 17; William J. Carney, The Production of Corporate Law, 71 S. CAL. L. REV. 715 (1998); John C. Coffee, Jr., The Future of Corporate Federalism: State Competition and the New Trend Toward De Facto Federal Minimum Standards, 8 CARDOZO L. REV. 759, 761-62 (1987); Macey \& Miller, supra note 17; Richard L. Revesz, Federalism and Environmental Regulation: A Public Choice Analysis, 115 HARV. L. REV. 553 (2001).

162. See supra note 11 ; $c$. Lucian Arye Bebchuk, Federalism and the Corporation: The Desirable Limits on State Competition in Corporate Law, 105 HARV. L. REV. 1435, 1452-54 (1992) (contending that "the appropriate assumption is that a state's interest in attracting incorporations shapes the behavior of the individuals 
gued elsewhere, "this account represents an oversimplification of the political process. Individual legislators cannot fully internalize the benefits of increased tax revenues, which are in effect a public good." 163 We have shown that in the competition for trust business, states respond to competitive pressures, but it is impossible to link their incentive for doing so to immediate tax or other direct revenue increases. To repeat, only those states that did not levy an income tax on trust funds attracted from out of state experienced an increase in trust business from abolishing the Rule Against Perpetuities.

True, in states that did not tax such trusts revenue may have increased indirectly owing to taxes paid by financial institutions, their employees, and local lawyers. Assuming typical industry commission schedules, the $\$ 100$ billion in trust funds that have moved carry with them perhaps as much as $\$ 1$ billion in yearly trustees' commissions. ${ }^{164}$ Attracting trust business "is good for a state's economy."165 But this is our point. The story of jurisdictional competition in trust law is a story of successful lobbying by local banks and trust lawyers, the principal beneficiaries of attracting new trust business to the state. ${ }^{166}$ On this account, whether jurisdictional competition leads to a race to the top, a race to the bottom, or somewhere in between depends on whether the relevant interest group dynamic will prompt private-interest or public-regarding legislation.

The genesis of the Alaska legislation in a fishing trip between two lawyers and a banker is a telling anecdote. ${ }^{167}$ Alaska did not seek to attract trust business; rather, a group of people who stood to benefit from a change in Alaska law persuaded Alaska lawmakers to do so. Moreover, Alaska has neither a fiduciary nor a personal income tax. As Sterk has observed, "Jurisdictions seeking to become trust havens ... . appear content to draw business to local financial institutions and lawyers, even without direct benefit to the public fisc."

actually involved in the state's lawmaking process").

163. Sitkoff, supra note 17 , at 1143-44.

164. See supra note 138.

165. Sterk, supra note 32 , at 2103.

166. We thus extend the lawyer-focused analysis of Macey and Miller to include transactional lawyers in addition to litigators. See Macey \& Miller, supra note 17. In separate work one of us finds a similar phenomenon in the jurisdictional competition for statutory business trusts, which unlike corporations (but like private trusts) do not pay franchise taxes. See Robert H. Sitkoff, The Rise of the Statutory Business Trust (manuscript on file with authors); Robert H. Sitkoff, Trust as Uncorporation: A Research Agenda, 2005 U. ILL. L. REV. 31 (2005). In a related vein, Larry Ribstein has argued that lawyer licensing "encourages lawyers to participate in lawmaking by capitalizing the benefits of their law-improvement efforts in the value of the law license." Larry E. Ribstein, Lawyers as Lawmakers: A Theory of Lawyer Licensing, 69 Mo. L. REV. 299, 299 (2004).

167. See text accompanying supra note 76 .

168. Sterk, supra note 74, at 1060. 
Second, our results suggest that prior work that is based on the tax-revenue model, in which states are assumed to behave like profitmaximizing firms, should be reconsidered. For example, based on calculations that show poaching incorporations from Delaware would not significantly increase the tax revenue of Nevada or other states, Kahan and Kamar have argued that jurisdictional competition in corporate law is a "myth."169 In a similar vein, drawing on the theory of industrial organization, Bebchuk and Hamdani have argued that there is little jurisdictional competition in corporate law because "a challenge to Delaware's dominance by some other small state is unlikely to be profitable." 170 In our view, these approaches are based on a flawed premise. Even if attracting business does not have an immediate impact on a state's tax revenue, local interest groups may nonetheless benefit from, and hence lobby for, laws that will attract new business. ${ }^{171}$ As we have seen, despite the lack of an immediate resulting increase in state tax revenue, jurisdictional competition is manifestly a force in the context of trust law. There is an ongoing race to abolish the Rule Against Perpetuities, and so far the prize is on the order of $\$ 100$ billion in trust business.

\section{Federal Wealth Transfer Taxes}

The extent to which the federal government should tax inter vivos and testamentary wealth transfers is currently before Congress. ${ }^{172}$ Naturally, there is a thick academic literature on this question. ${ }^{173}$

169. Kahan \& Kamar, supra note 16. In fairness, it must be noted that Kahan and Kamar do give some attention to the public choice considerations we emphasize. See id. at 694-99 (examining the incentives of local lawyers); id. at 728-30 (criticizing the model of states as profit seekers).

170. See Bebchuk \& Hamdani, supra note 16, at 557.

171. In a contemporaneous work, Roberta Romano offers a similar but more extended criticism of both the Kahan and Kamar and the Bebchuk and Hamdani articles. See Roberta Romano, Is Regulatory Competition a Problem or Irrelevant for Corporate Governance? 16-26 (Yale L. \& Econ. Res. Paper No. 307, 2005) available at http://ssrn.com/abstract $=693484$.

172. For example, on April 13, 2005, the House of Representatives voted to make permanent the repeal of the estate and GST taxes that currently will take effect in 2010 for one year. Death Tax Repeal Permanency Act, H.R. 8, 109th Cong. (Roll No. 102, Apr. 13, 2005).

173. See, e.g., Mark L. Ascher, Curtailing Inherited Wealth, 89 MICH. L. REV. 69 (1990); Karen C. Burke \& Grayson M.P. McCouch, A Consumption Tax on Gifts and Bequests?, 17 VA. TAX REV. 657 (1998); Joseph M. Dodge, Comparing a Reformed Estate Tax with an Accessions Tax and an Income-Inclusion System, and Abandoning the Generation-Skipping Tax, 56 S.M.U. L. REV. 551 (2003); Michael J. Graetz, To Praise the Estate Tax, Not to Bury It, 93 YALE L.J. 259 (1983); Wojciech Kopczuk \& Joel Slemrod, Tax Consequences on Wealth Accumulation and Transfers of the Rich, in in DEATH AND DOLLARS: THE ROLE OF GIFTS AND BEQUESTS IN AMERICA 213 (Alicia H. Munnell \& Annika Sundén eds., 2003); Edward J. McCaffery, The Uneasy Case for Wealth Transfer Taxation, 104 YALE L.J. 283 (1994); Col- 
Without getting embroiled in that debate, we make two modest observations. First, our results are consistent with other studies showing that people undertake significant measures to avoid these taxes.

Second, if Congress wants to close the old loophole for successive life estates, it must decouple the duration of the GST tax exemption from state perpetuities law, a step that Congress is beginning to consider. On January 27, 2005, the Staff of the Joint Committee on Taxation (JCT) issued a report in which it proposed closing the perpetuities loophole in the GST tax by prohibiting the allocation of the transfer-tax exemption to a trust for the benefit of a generation more remote than the transferor's grandchildren. ${ }^{174}$ The report gives two reasons for closing the loophole: (1) "[p]erpetual dynasty trusts are inconsistent with the" purpose of the GST tax, and (2) "perpetual dynasty trusts deny equal treatment of all taxpayers because such trusts can only be established in the States that have repealed the mandatory rule against perpetuities." 175

Our findings cast doubt on the importance of the JCT report's second rationale. We do not deny that there may be additional transactions costs to establishing a trust out-of-state. But our results show that settlors in states that have retained the Rule have not found these transaction costs to be prohibitive. On the other hand, for this reason our findings strongly support the JCT report's first rationale, namely, that the federal wealth transfer taxes can easily be avoided in a manner that Congress did not intend.

loquium, Wealth Transfer Taxation, 51 TAX L. REV. 357 (1996) (discussing McCaffery's proposal to abolish the federal estate and gift tax); James R. Repetti, Democracy, Taxes, and Wealth, 76 N.Y.U. L. REV. 825 (2001); see also RETHINKING ESTATE AND GIFT TAXATION (William G. Gale et al., eds., 2001) (collecting eleven essays on the debate over estate taxation).

174. See JoInt COMM. ON TAXATION, supra note 13, at 392-95. Our gross summary glosses over some of the proposal's finer details. For other proposals, see John G. Shively, Note, The Death of the Life in Being-The Required Federal Response to State Abolition of the Rule Against Perpetuities, 78 WASH. U. L.Q. 371, 39295 (2000); Report on Reform, supra note 50, at 268-74.

175. JOINT COMM. ON TAXATION, supra note 13, at 393. The report also projects that $\$ 300$ million in tax revenue would be gained from 2005 through 2014 from closing the perpetuities loophole in the GST tax. Id. at 428. We are dubious of the report's revenue projection. As detailed above, our data do not allow us to estimate the tax revenue that would be gained from closing the perpetuities loophole in the GST tax, and there is no indication that the Committee staff has better data. According to a later report, the Committee's estate and gift tax revenue projections are based on a sample of estate tax returns drawn from those filed in 2001. JOINT COMMITTEE ON TAXATION, OVERVIEW OF REVENUE ESTIMATING PROCEDURES AND Methodologies USED BY THE StAFF OF THE JOINT COMMITTEE ON TAXATION 32 (2005), available at http:/www.house.gov/jct/x-1-05.pdf. We are skeptical, however, that one can make a reliable estimate of the number and volume of transfertax-exempt perpetual trusts, and then incorporate actuarial information about the trusts' beneficiaries, from a sampling of estate tax returns. Neither Committee report provides further specifics on the Committee's estimation methodology. 


\section{CONCLUSION}

This Essay presents the results of the first empirical study of the domestic jurisdictional competition for trust funds. In order to take advantage of a loophole in the federal estate tax, a host of states have abolished the Rule Against Perpetuities. In order to allow settlors to shield their assets from creditors, a handful of states have validated self-settled asset protection trusts. Both abolishing the Rule and validating asset protection trusts represent significant departures from the common law of trusts.

Using standard difference-in-difference regression analysis of state-level panel data assembled from annual reports to federal banking authorities by institutional trustees, we estimate that through 2003 a state's abolition of the Rule increased its trust assets by $\$ 6$ billion (a $20 \%$ increase on average) and increased its average trust account size by $\$ 200,000$. These estimates imply that roughly $\$ 100$ billion in trust funds have moved to take advantage of the abolition of the Rule. By contrast, our examination of validating self-settled asset protection trusts yielded indeterminate results. We intend to reexamine the effect of validating asset protection trusts when more data becomes available.

Interestingly, states that levied an income tax on trust funds attracted from out of state experienced no observable increase in trust business from abolishing the Rule Against Perpetuities. Because this finding implies that abolishing the Rule does not directly increase a state's tax revenue, it bears on the current scholarly debate over the nature of jurisdictional competition. In spite of the lack of direct tax revenue from attracting trust business, the jurisdictional competition for trust funds is patently real and profound. Accordingly, we believe that jurisdictional competition in trust law is best understood in light of public-choice theory. The immediate benefits of attracting new trust business flow to local lawyers and institutional trustees.

In addition to their theoretical implications, our findings also speak to live policy issues concerning state property law and federal tax law. Even if some states retain the Rule Against Perpetuities, the Rule will in effect apply only to real property within those states. When it matters, people move their financial assets to escape the Rule's reach. The federal wealth transfer taxes have thus mortally wounded the once-mighty Rule by reducing it to a mere transaction cost. As a result, Congress has inadvertantly transformed the question of trust duration into an issue of federal tax law. If Congress wants to 
[Vol. nn:nnn

close the successive-life-estates loophole in the transfer taxes, it must decouple the duration of the GST tax exemption from state perpetuities law. 
Figure 1: Total Reported Trust Assets and Average Account Size

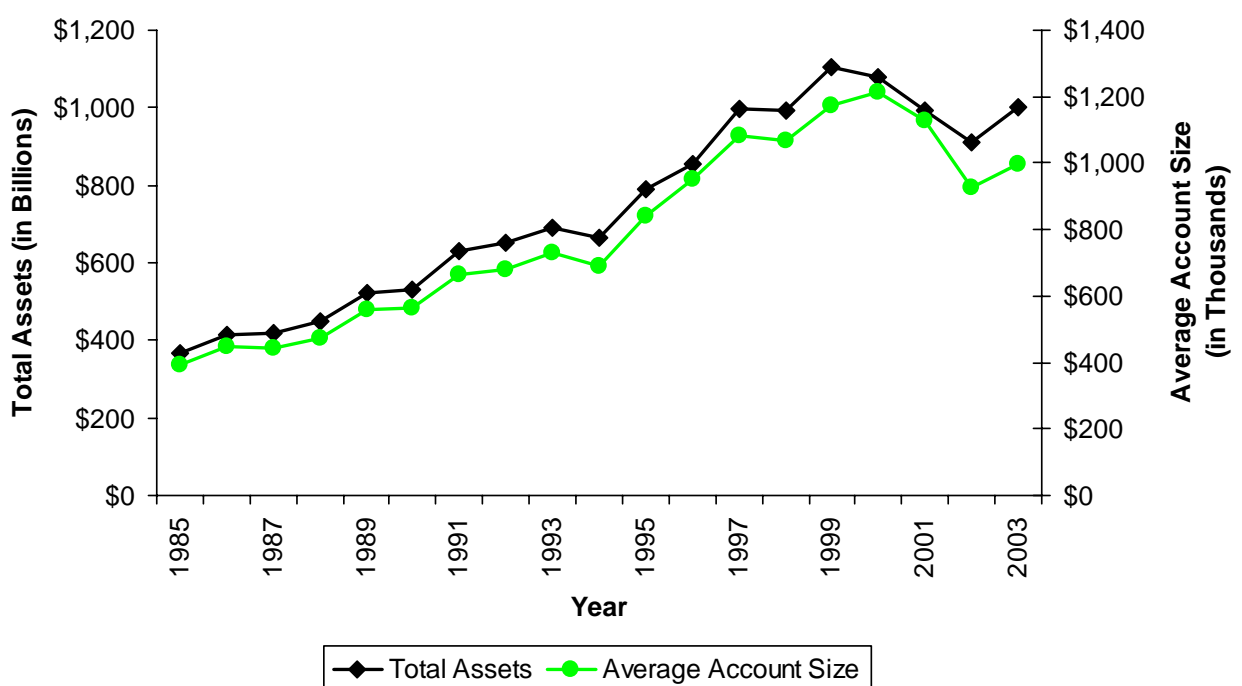

Figure 2: Reported Trust Assets per Person in Delaware, New York, and South Dakota

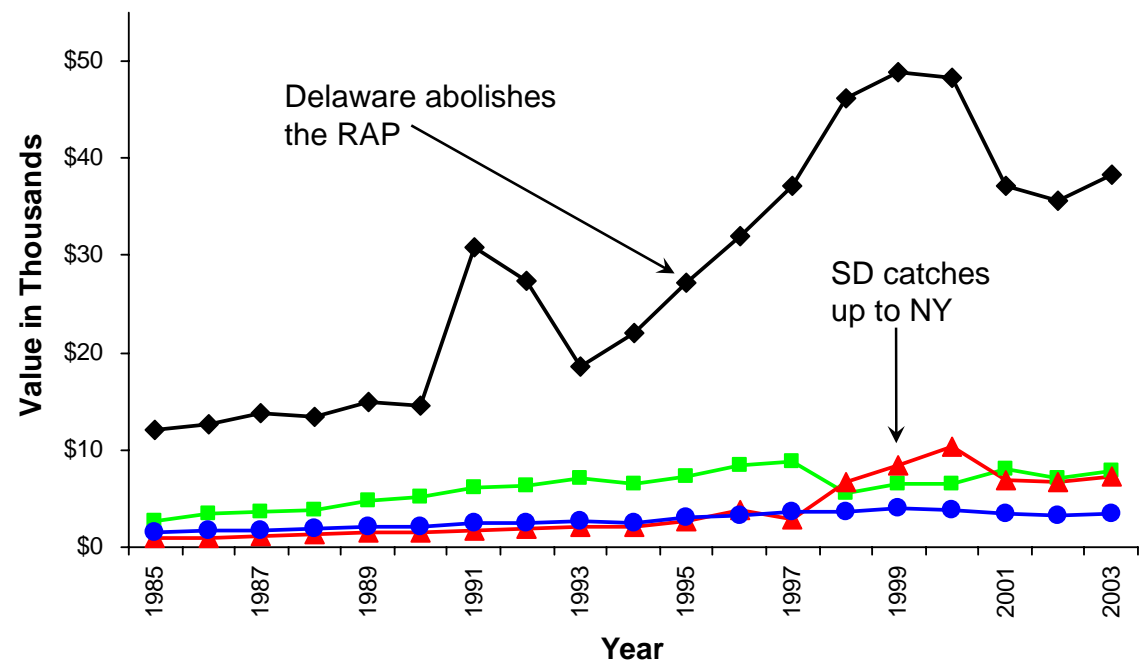

$\neg$ Delaware $\rightarrow-$ New York $₫$ South Dakota $\rightarrow$ National Average 
Figure 3: Average Account Size in

Delaware and Comparison States

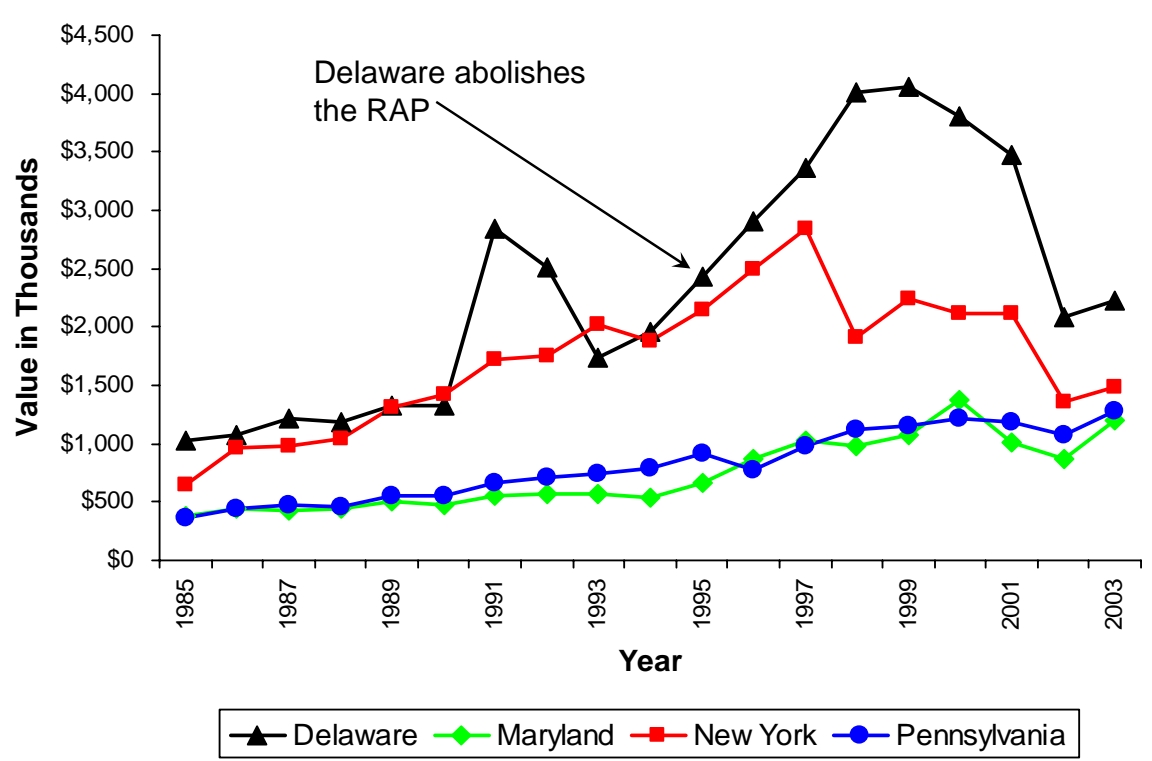

Figure 4: Average Account Size in South Dakota and Comparison States

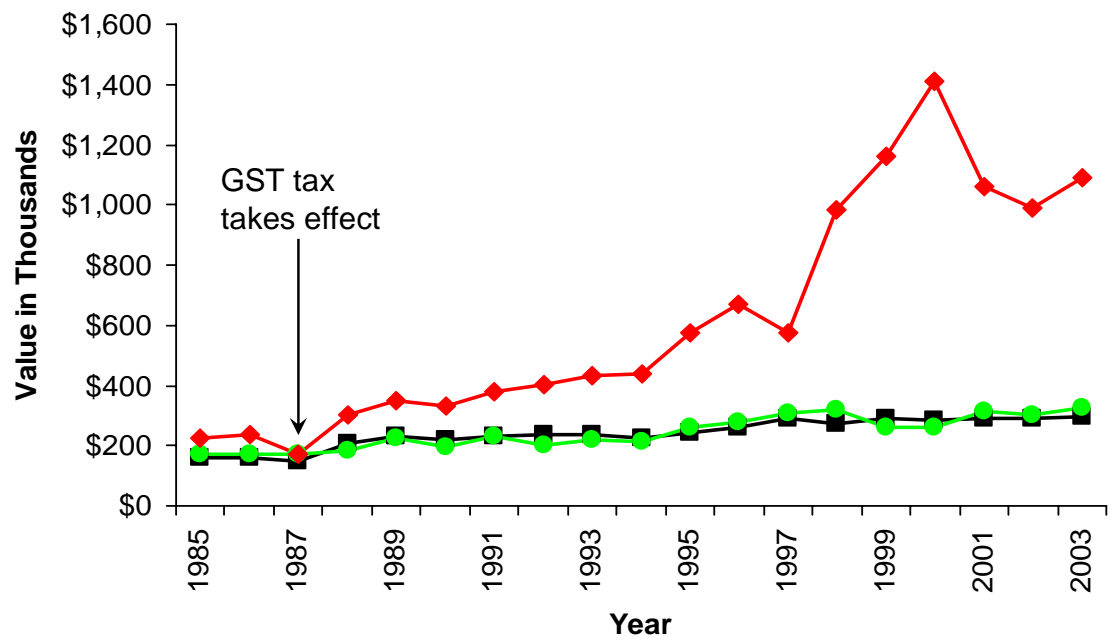

$\rightarrow-$ lowa $\multimap-$ North Dakota $\leadsto$ South Dakota 
Figure 5: Average Account Size

in Illinois and Comparison States

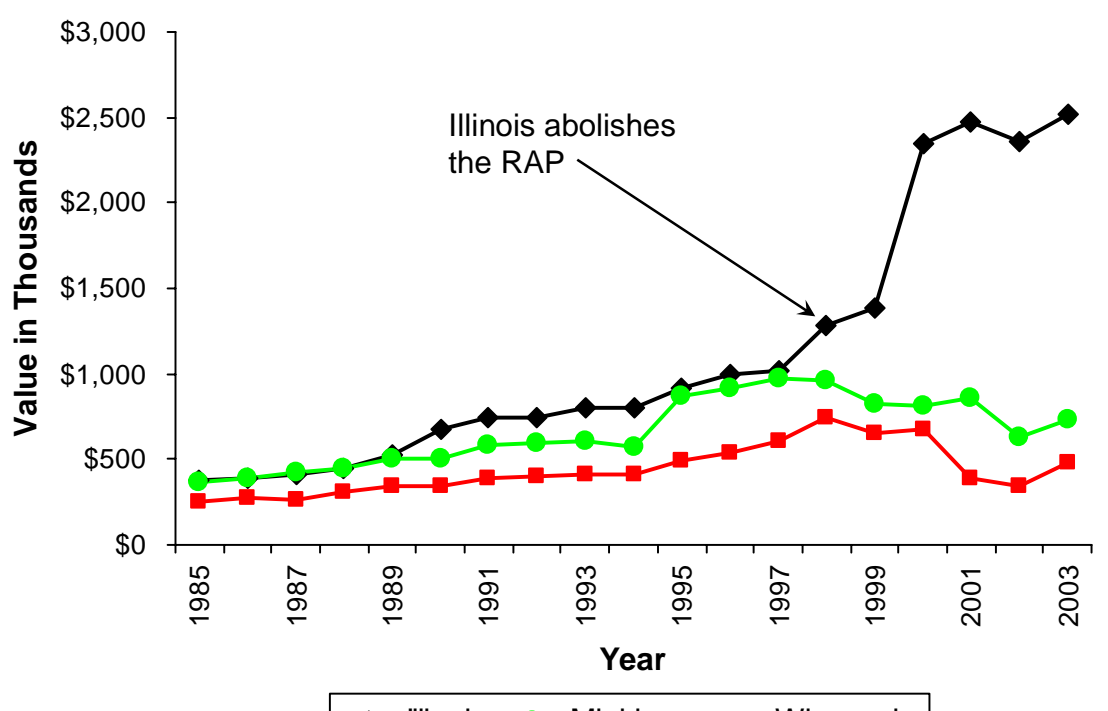

$\neg$ Illinois $\multimap-$ Michigan $\rightarrow-$ Wisconsin

Figure 6: Average Account Size in

Delaware, Illinois, New York, and South Dakota

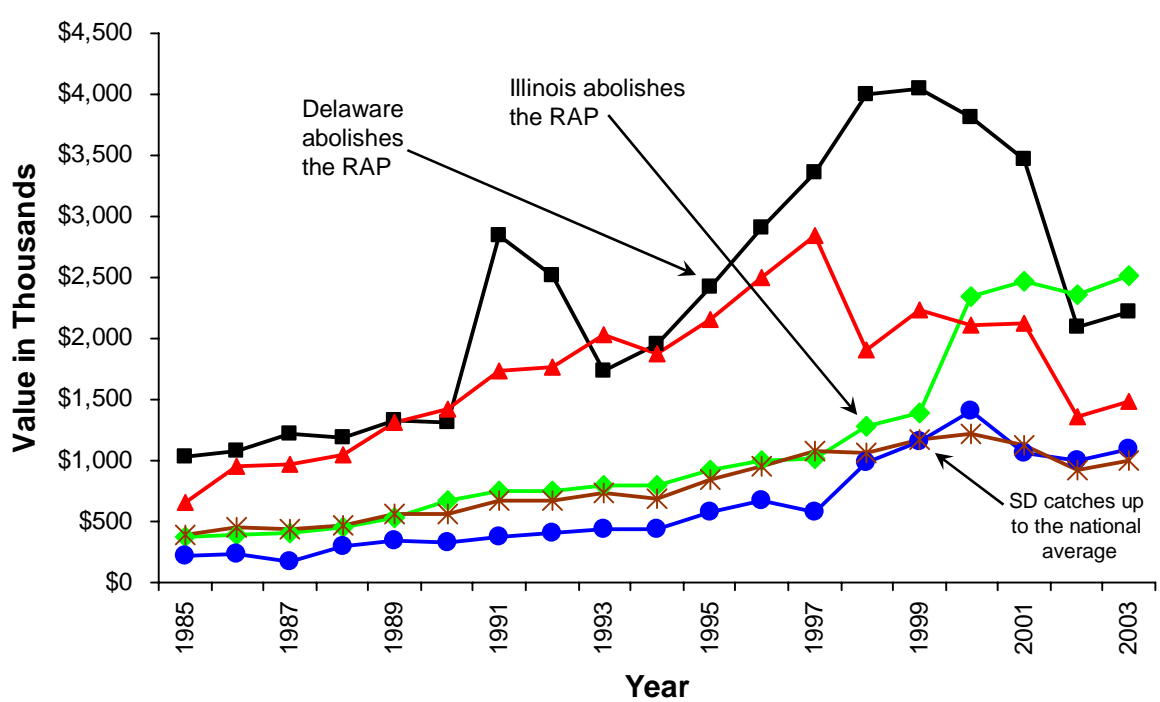

Delaware $\multimap$ Illinois $\multimap-$ New York $\multimap-$ South Dakota $\rightarrow$ National Average 

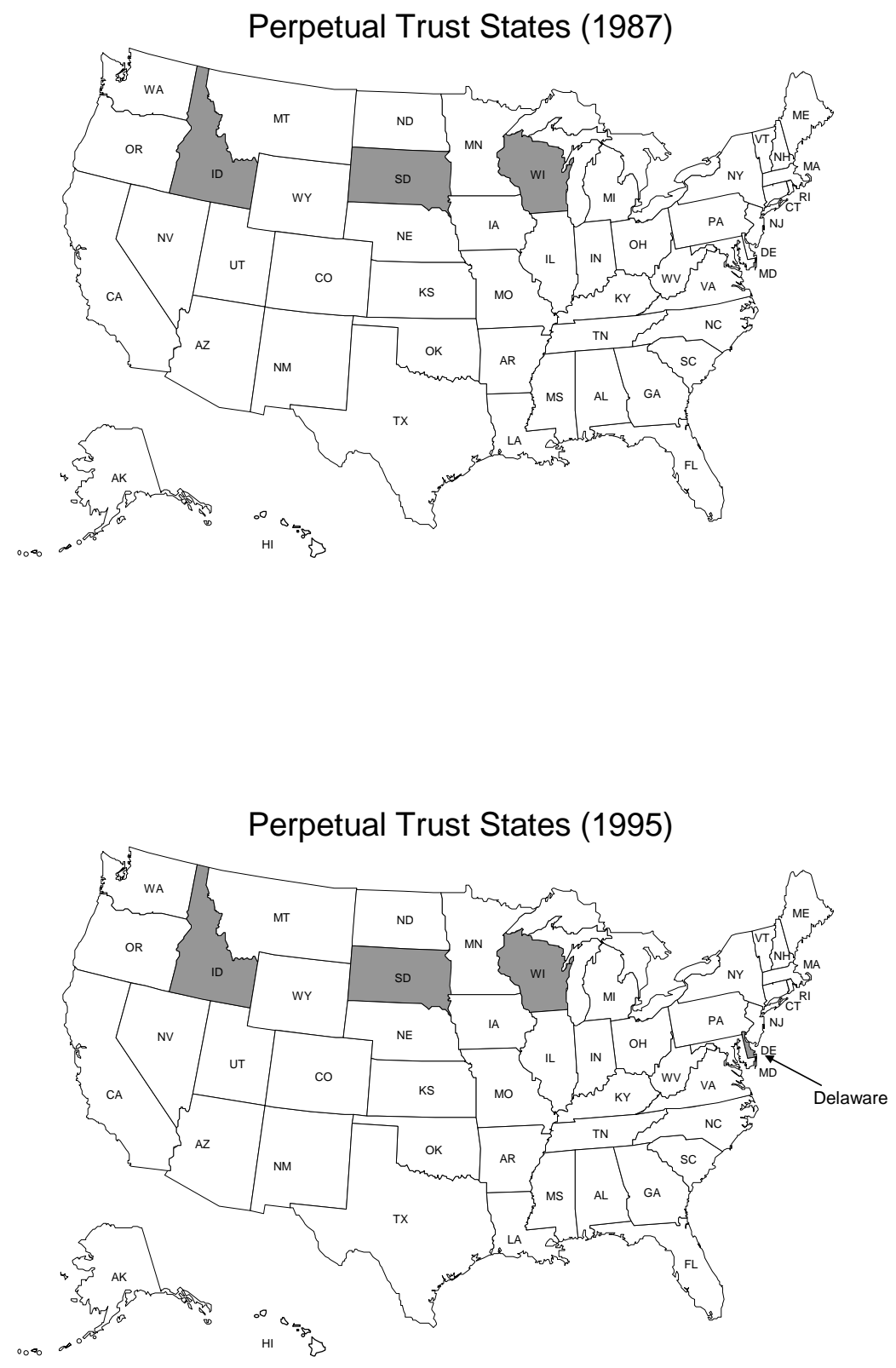

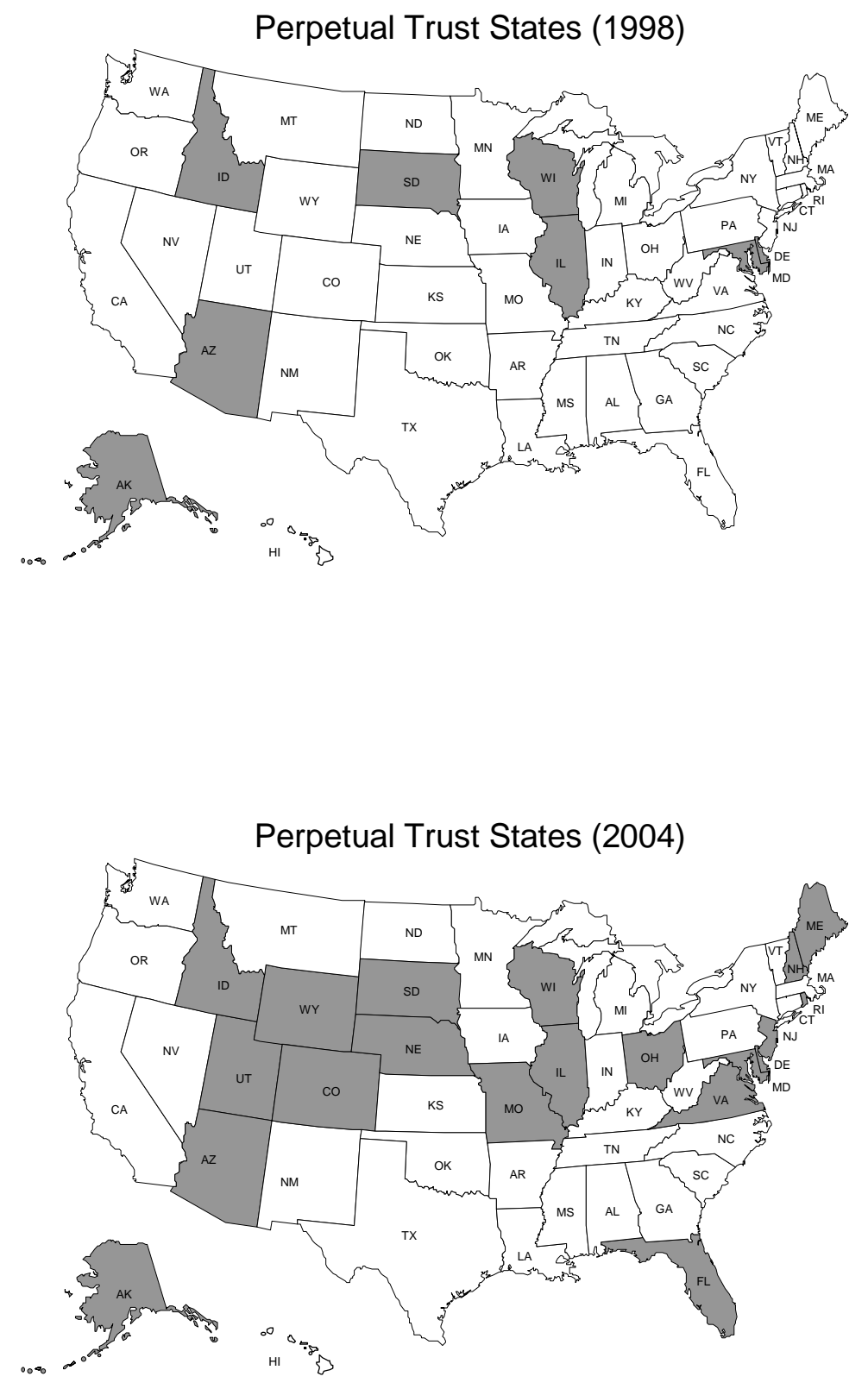


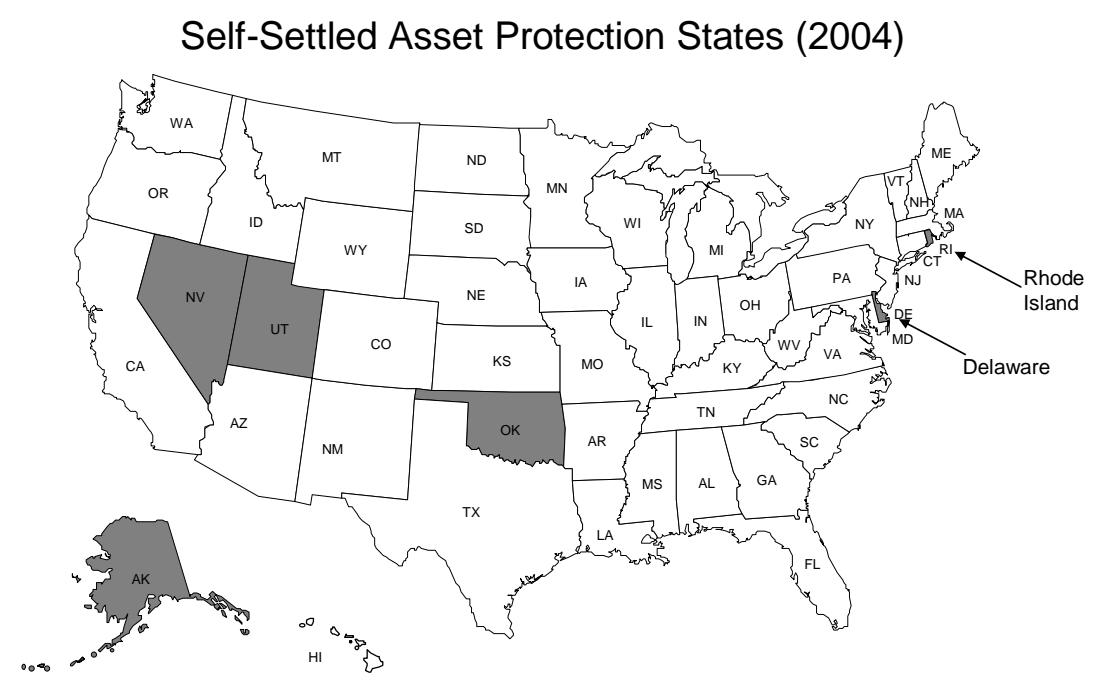


TABle 1: RePorted State Trust Assets (In BILLIONS)

\begin{tabular}{|c|c|c|c|c|c|c|c|c|}
\hline Variable & Model 1 & Model 2 & Model 3 & Model 4 & Model 5 & Model 6 & Model 7 & Model 8 \\
\hline $\begin{array}{l}\text { Abolish RAP } \\
\text { Abolish*NoFIT }\end{array}$ & $\begin{array}{l}6.63^{*} \\
(2.93)\end{array}$ & $\begin{array}{r}6.02 * \\
(2.75)\end{array}$ & $\begin{array}{l}5.82^{*} \\
(2.77)\end{array}$ & $\begin{array}{l}3.97 * \\
(1.70)\end{array}$ & $\begin{array}{l}6.08^{*} \\
(3.13)\end{array}$ & $\begin{array}{c}-.98 \\
(1.79) \\
14.0^{* *} \\
(4.51)\end{array}$ & & \\
\hline Year Abolish & & & $\begin{array}{l}.001 \\
\quad(3.52)\end{array}$ & & & & & \\
\hline Year Before Abolition & & & $\begin{array}{r}-1.98 \\
\quad(2.10)\end{array}$ & & & & & \\
\hline $\begin{array}{l}\text { Two Years Before } \\
\text { Abolition }\end{array}$ & & & $\begin{array}{r}-1.63 \\
(1.40)\end{array}$ & & & & & \\
\hline Years Abolished & & & & & & & $\begin{array}{l}\text { 2.18* } \\
\quad(1.37)\end{array}$ & $\begin{array}{l}.35 \\
(.49)\end{array}$ \\
\hline $\begin{array}{l}\text { Years Abolished } \\
\text { Squared }\end{array}$ & & & & & & & $\begin{array}{c}-.13 * * \\
(.05)\end{array}$ & $\begin{array}{l}-.07^{+} \\
(.040)\end{array}$ \\
\hline $\begin{array}{l}\text { Years Abolished *No } \\
\text { FIT }\end{array}$ & & & & & & & & $\begin{array}{l}4.97 * * \\
(1.53)\end{array}$ \\
\hline $\begin{array}{l}\text { Years Abolished } \\
\text { Squared*NoFIT }\end{array}$ & & & & & & & & $\begin{array}{l}-.18 * \\
\quad(.08)\end{array}$ \\
\hline APTs & & $\begin{array}{l}3.30 \\
(2.43)\end{array}$ & $\begin{array}{l}3.42 \\
(2.47)\end{array}$ & $\begin{array}{l}-6.85 * \\
(2.63)\end{array}$ & & $\begin{array}{r}-1.49 \\
(3.53)\end{array}$ & $\begin{array}{l}1.89 \\
(2.74)\end{array}$ & $\begin{array}{r}-2.17 \\
(2.13)\end{array}$ \\
\hline USRAP & & $\begin{array}{l}2.62^{+} \\
\quad(1.53)\end{array}$ & $\begin{array}{l}2.60^{+} \\
\quad(1.53)\end{array}$ & $\begin{array}{l}1.77 \\
\quad(1.53)\end{array}$ & $\begin{array}{l}3.81^{*} \\
\quad(1.66)\end{array}$ & $\begin{array}{l}3.35 * \\
\quad(1.55)\end{array}$ & $\begin{array}{l}2.67^{+} \\
\quad(1.54)\end{array}$ & $\begin{array}{l}3.00^{+} \\
\quad(1.61)\end{array}$ \\
\hline NoFIT & & $\begin{array}{r}-1.53 \\
(1.95)\end{array}$ & $\begin{array}{r}-1.52 \\
\quad(1.96)\end{array}$ & $\begin{array}{r}-1.56 \\
\quad(1.45)\end{array}$ & $\begin{array}{l}-1.74 \\
\quad(1.91)\end{array}$ & $\begin{array}{l}-6.51^{*} \\
(3.03)\end{array}$ & $\begin{array}{r}-.026 \\
\quad(1.80)\end{array}$ & $\begin{array}{r}-2.17 \\
\quad(2.13)\end{array}$ \\
\hline Population (Millions) & & $\begin{array}{r}-10.8^{* *} \\
(2.31)\end{array}$ & $\begin{array}{r}-10.7 * * \\
(2.32)\end{array}$ & $\begin{array}{l}3.59 \\
\quad(4.41)\end{array}$ & $\begin{array}{r}-11.0^{* *} \\
(2.31)\end{array}$ & $\begin{array}{l}-9.61 * * \\
(2.31)\end{array}$ & $\begin{array}{c}-10.4^{* *} \\
(2.31)\end{array}$ & $\begin{array}{c}-9.56^{* *} \\
(2.32)\end{array}$ \\
\hline $\begin{array}{l}\text { Gross State Income } \\
\text { (Billions) }\end{array}$ & & $\begin{array}{l}.20 * * \\
(.03)\end{array}$ & $\begin{array}{l}.20 * * \\
(.03)\end{array}$ & $\begin{array}{c}.20 * * \\
(.07)\end{array}$ & $\begin{array}{c}.20 * * \\
(.06)\end{array}$ & $\begin{array}{l}.19 * * \\
(.03)\end{array}$ & $\begin{array}{r}.20 * * \\
(.07)\end{array}$ & $\begin{array}{r}.18 * * \\
(.08)\end{array}$ \\
\hline $\begin{array}{l}\text { Test Abolish, APT, } \\
\text { Abolish*NoFIT }\end{array}$ & & .0030 & .0041 & .0103 & & .0004 & & \\
\hline Test $\mathrm{Yr}, \mathrm{Yr}^{2},{ }^{2}$ NoFIT & & & & & & & .032 & .001 \\
\hline R-Square & .7736 & .8044 & .8045 & .9267 & .8046 & .8071 & .8066 & .8047 \\
\hline State-Specific Trends & No & No & No & Yes & No & No & No & No \\
\hline Exc. AK, DE, RI, MA, & No & No & No & No & Yes & No & No & No \\
\hline
\end{tabular}




\section{TABLE 2: LOG REPORTED STATE TRUST ASSETS}

\begin{tabular}{|c|c|c|c|c|c|c|}
\hline & Model 1 & Model 2 & Model 3 & Model 4 & Model 5 & Model 6 \\
\hline Abolish RAP & $\begin{array}{l}.23 * \\
(.10)\end{array}$ & $\begin{array}{l}.20 * \\
(.10)\end{array}$ & $\begin{array}{l}.17 * \\
(.08)\end{array}$ & $\begin{array}{r}-.07 \\
(.14)\end{array}$ & & \\
\hline Abolish*NoFIT & & & & $\begin{array}{r}.52 * * \\
(.17)\end{array}$ & & \\
\hline Years Abolished & & & & & $\begin{array}{r}.025 \\
(.049)\end{array}$ & $\begin{array}{r}.002 \\
(.04)\end{array}$ \\
\hline $\begin{array}{l}\text { Years Abolished } \\
\text { Squared }\end{array}$ & & & & & $\begin{array}{l}-.003 \\
\quad(.003)\end{array}$ & $\begin{array}{l}-.01 * * \\
\quad(.003)\end{array}$ \\
\hline Years Abolished & & & & & & $.16 * *$ \\
\hline *NoFIT & & & & & & $(.053)$ \\
\hline $\begin{array}{l}\text { Years Abolished } \\
\text { Squared*NoFIT }\end{array}$ & & & & & & $\begin{array}{r}.009 * * \\
(.003)\end{array}$ \\
\hline APTs & & .28 & ${ }^{-.04}(.22)$ & .09 & $.33(.24)$ & -.15 \\
\hline USRAP & & $\begin{array}{l}.092 \\
(.056)\end{array}$ & $\begin{array}{r}.035 \\
(.05)\end{array}$ & ${ }^{.11^{*}}(.056)$ & $\begin{array}{l}.06 \\
(.05)\end{array}$ & $\begin{array}{ll}.06 & \\
& \\
(.053)\end{array}$ \\
\hline NoFIT & & $\begin{array}{l}-.29^{+} \\
(.15)\end{array}$ & -.17 (.16) & $\begin{array}{c}-.41 * * \\
(.16)\end{array}$ & -.16 & $\begin{array}{l}.056 \\
(.09)\end{array}$ \\
\hline Population (Millions) & & $\begin{array}{r}-.19 * * \\
(.05)\end{array}$ & .15 (.10) & $\begin{array}{r}-.15 * * \\
(.05)\end{array}$ & $\begin{array}{r}-.19 * * \\
(.06\end{array}$ & $\begin{array}{r}-.14^{* *} \\
(.045)\end{array}$ \\
\hline $\begin{array}{l}\text { Gross State Income } \\
\text { (Billions) }\end{array}$ & & $\begin{array}{r}.003^{* *} \\
(.001) \\
\end{array}$ & $\begin{array}{r}-.0001 \\
(.001) \\
\end{array}$ & $\begin{array}{r}.002 * * \\
(.0005) \\
\end{array}$ & $\begin{array}{r}.002 * * \\
(.001) \\
\end{array}$ & $\begin{array}{r}.003^{* *} \\
(.0004) \\
\end{array}$ \\
\hline $\begin{array}{l}\text { Test Abolish, APT, } \\
\text { Abolish*NoFIT }\end{array}$ & & .0248 & .1152 & .0002 & & \\
\hline Test Yr, $\mathrm{Yr}^{2}, *$ NoFIT & & & & & .1332 & $<.0001$ \\
\hline R-Square & .9104 & .9127 & .9619 & .9138 & .9199 & .9199 \\
\hline State-Specific Trends & No & No & Yes & No & No & No \\
\hline
\end{tabular}

$\mathrm{N}=940$ for columns $1-5$ and 7-8; $\mathrm{N}=874$ for column $3 .{ }^{* *}$ sig. at $<.01$ level; ${ }^{*}$ sig. at $<.05$ level; ${ }^{+}$sig. at $<.10$ level. HuberWhite robust standard errors reported in parentheses. All regressions include state and year dummies and a constant. Years 1985-2003. 
Table 3: State Average Account Size (In Thousands)

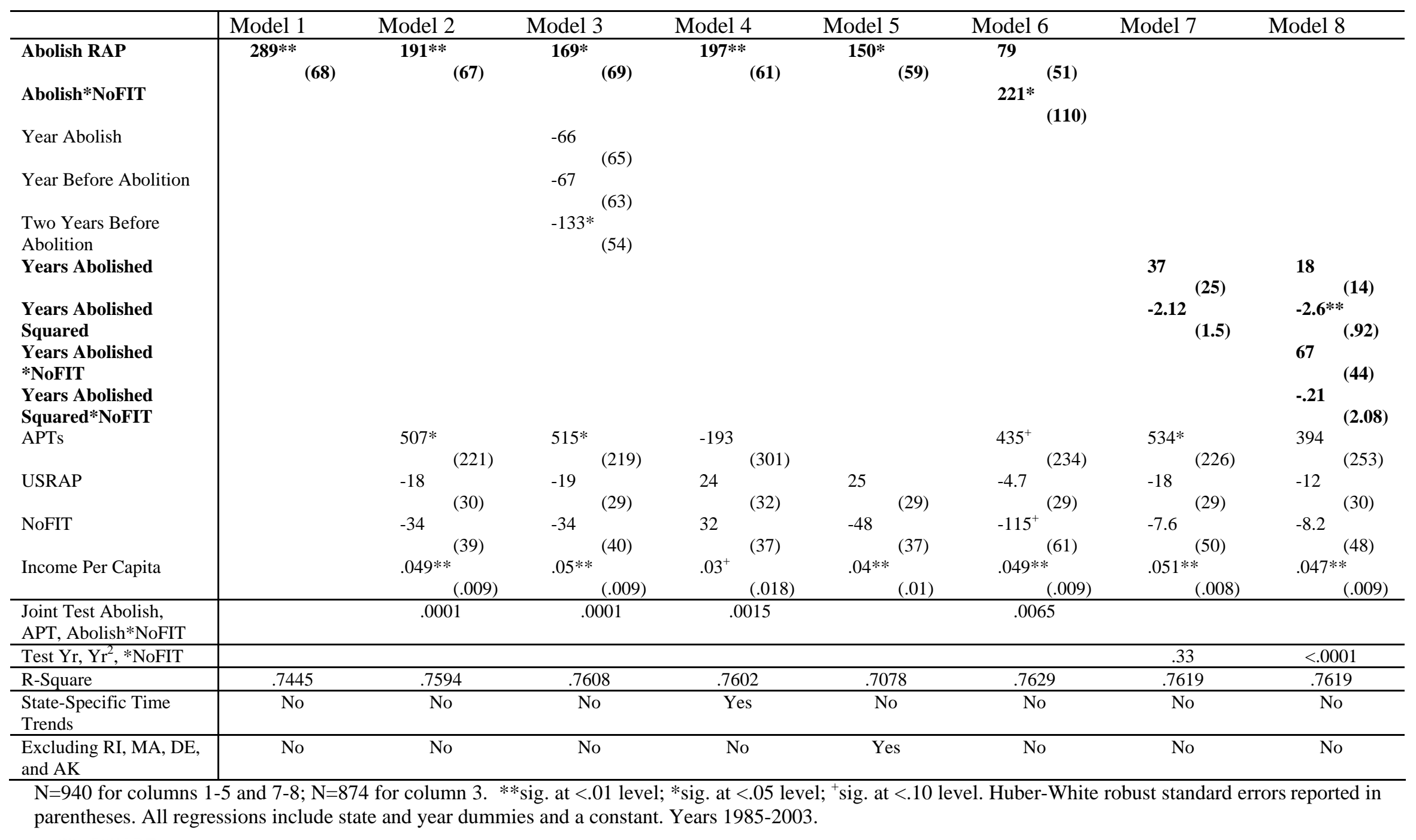


TABle 4: RePorted Number of State Accounts (In Thousands)

\begin{tabular}{|c|c|c|c|c|c|c|}
\hline & Model 1 & Model 2 & Model 3 & Model 4 & Model 5 & Model 6 \\
\hline $\begin{array}{l}\text { Abolish RAP } \\
\text { Abolish*NoFIT }\end{array}$ & $\begin{array}{ll}.47 & \\
& (2.32)\end{array}$ & $\begin{array}{ll}.82 & (2.48) \\
& \end{array}$ & $\begin{array}{ll}1.51 & \\
& (1.51)\end{array}$ & $\begin{array}{l}-2.94^{+} \\
7.54^{+} \\
\\
\end{array}$ & & \\
\hline Years Abolished & & & & & $\begin{array}{ll}.67 & \\
& (.69)\end{array}$ & $\begin{array}{ll}-.09 & \\
& (.45)\end{array}$ \\
\hline $\begin{array}{l}\text { Years Abolished } \\
\text { Squared }\end{array}$ & & & & & $\begin{array}{r}-.056 \\
(.040)\end{array}$ & $\begin{array}{ll}.47 & \\
& (.33)\end{array}$ \\
\hline $\begin{array}{l}\text { Years Abolished } \\
\text { *NoFIT }\end{array}$ & & & & & & $2.22(1.28)$ \\
\hline $\begin{array}{l}\text { Years Abolished } \\
\text { Squared*NoFIT }\end{array}$ & & & & & & $\begin{array}{ll}-.51 & \\
& (.65)\end{array}$ \\
\hline APTs & & ${ }^{-.068}$ & ${ }^{-4.21 *}$ & $\begin{array}{l}-2.43 \\
(2.63)\end{array}$ & ${ }^{-.94}(1.81)$ & $\begin{array}{l}-5.03 \\
(3.43)\end{array}$ \\
\hline USRAP & & $3.34 *$ & .74 & ${ }^{3.69 *}(1.24)$ & $\begin{array}{l}3.49 * \\
(1.22)\end{array}$ & $\begin{array}{l}3.29 * \\
(1.22)\end{array}$ \\
\hline NoFIT & & $\begin{array}{r}-6.43^{* *} \\
(2.00)\end{array}$ & $\begin{array}{l}-4.21^{*} \\
(1.84)\end{array}$ & $\begin{array}{r}-9.00^{* *} \\
(2.71)\end{array}$ & $\begin{array}{r}-5.22 * * \\
(1.88)\end{array}$ & $\begin{array}{r}-5.62 * * \\
(2.03)\end{array}$ \\
\hline Population (Millions) & & $\begin{array}{ll}-.38 & \\
& (2.05)\end{array}$ & 1.35 & $.20 \quad(2.00)$ & $\begin{array}{ll}-.32 & \\
(2.05)\end{array}$ & $\begin{array}{ll}-.25 & \\
& (2.0)\end{array}$ \\
\hline $\begin{array}{l}\text { Gross State Income } \\
\text { (Billions) }\end{array}$ & & ${ }^{-.015}(.23)$ & $\begin{array}{r}-.050 \\
\quad(.040) \\
\end{array}$ & $\begin{array}{r}-.086 \\
(.26) \\
\end{array}$ & $\begin{array}{r}-.026 \\
(.23) \\
\end{array}$ & $\begin{array}{r}-.013 \\
(.23) \\
\end{array}$ \\
\hline $\begin{array}{l}\text { Joint test Years, } \\
\text { Years }^{2}, * \text { NoFIT }\end{array}$ & & & & & .0423 & .0001 \\
\hline $\begin{array}{l}\text { State-Specific Time } \\
\text { Trends }\end{array}$ & No & No & Yes & No & No & No \\
\hline R-Square & .8239 & .8270 & .9301 & .8279 & .8274 & 8274 \\
\hline
\end{tabular}

$\mathrm{N}=940$ for columns $1-5$ and $7-8 ; \mathrm{N}=874$ for column $3 .{ }^{* *}$ sig. at $<.01$ level; ${ }^{*}$ sig. at $<.05$ level; ${ }^{+}$sig. at $<.10$ level. Huber-White robust standard errors reported in parentheses. All regressions include state and year dummies and a constant. Years 1985-2003. 
TABLE 5: TRUST LAW CODING ${ }^{1}$

\begin{tabular}{|c|c|c|c|c|}
\hline State & $\begin{array}{c}\text { RAP } \\
\text { Abolished }^{2}\end{array}$ & USRAP & $\begin{array}{c}\text { Self-Settled } \\
\text { Asset Protection } \\
\text { Trust (APT) }\end{array}$ & $\begin{array}{c}\text { Fiduciary Income } \\
\text { Tax (FIT) }^{3}\end{array}$ \\
\hline Alabama & - & - & - & $\overline{\text { YES }}$ \\
\hline Alaska & $1997^{4}$ & $\begin{array}{c}1996, \\
\text { repealed } 2000\end{array}$ & 1997 & NO \\
\hline Arizona & 1998 & 1995 & - & YES \\
\hline Arkansas & - & - & - & $\mathrm{NO}$ \\
\hline California & - & 1992 & - & YES \\
\hline Colorado & 2001 & 1991 & -5 & YES \\
\hline Connecticut & - & 1989 & - & NO \\
\hline Delaware & $1995^{6}$ & - & 1997 & NO \\
\hline Florida & $2001^{7}$ & 1988 & - & $\begin{array}{c}\text { YES, }^{8} \\
\text { NO beginning } 2001\end{array}$ \\
\hline Georgia & - & 1990 & - & $\mathrm{NO}$ \\
\hline Hawaii & - & 1992 & - & $\mathrm{NO}$ \\
\hline Idaho & 1957 & - & - & YES \\
\hline Illinois & 1998 & & - & NO \\
\hline Indiana & - & 1991 & - & YES \\
\hline Iowa & - & - & - & YES \\
\hline Kansas & - & 1992 & - & YES \\
\hline Kentucky & - & - & - & YES \\
\hline
\end{tabular}

${ }^{1}$ Except as noted otherwise, this table is current as the statutes appeared on Lexis or Westlaw at year end 2004.

${ }^{2}$ Except as noted otherwise, we define abolition to include any reform that would allow a settlor to create a perpetual trust of intangible personal property. Accordingly, our definition of abolition includes: (1) outright repeal of the Rule Against Perpetuities with respect to interests in a trust funded with intangible personal property; (2) reconfiguration of the Rule with respect to such trusts as a default that applies unless the settlor provides otherwise in the trust instrument; and (3) an exemption from the Rule for interests in a trust funded with intangible personal property over which the trustee has the power to sell (i.e., the trust does not suspend the power of alienation). See supra note _ and text accompanying.

${ }^{3} \mathrm{~A}$ YES in this column indicates that the state might levy a fiduciary income tax on the basis of an instate trustee, in-state trust administration, or an in-state situs, even if the trust was settled by a nonresident for the benefit of nonresident beneficiaries and the trust consists entirely of intangible personal property. A NO indicates that state law clearly excludes such a trust from income taxation. We resolved ambiguity in favor of YES. See supra note _ and text accompanying.

${ }^{4}$ In 2000 Alaska established a 1000-year limitation on the duration of powers of appointment, enacted new language that more clearly abolishes the Rule Against Perpetuities, and repealed its enactment of USRAP.

${ }^{5}$ See supra note _.

${ }^{6}$ Prior to 1995 it was possible to have a perpetual trust in Delaware, but this option was rarely invoked because of I.R.C. §2041. See supra note _.

${ }^{7}$ In 2001 Florida amended its enactment of USRAP to provide for a 360-year perpetuities period for property held in trust. Because 360 years is significantly longer than is possible through the use of a saving clause, we count Florida as having abolished the Rule.

${ }^{8}$ Although Florida does not have a fiduciary income tax, it does have an intangible personal property tax, and before 2001 trustees of Florida situs trusts were required to pay this tax. 


\begin{tabular}{|c|c|c|c|c|}
\hline State & $\begin{array}{c}\text { RAP } \\
\text { Abolished }^{2}\end{array}$ & USRAP & $\begin{array}{c}\text { Self-Settled } \\
\text { Asset Protection } \\
\text { Trust (APT) }\end{array}$ & $\begin{array}{c}\text { Fiduciary Income } \\
\text { Tax (FIT) })^{3}\end{array}$ \\
\hline Louisiana & - & - & - & YES \\
\hline Maine & 1999 & - & - & YES \\
\hline Maryland & 1998 & - & - & $\begin{array}{c}\text { NO, } \\
\text { YES beginning } 1988\end{array}$ \\
\hline Massachusetts & - & 1990 & - & YES \\
\hline Michigan & - & 1988 & - & $\mathrm{NO}$ \\
\hline Minnesota & - & 1991 & - & $\mathrm{NO}$ \\
\hline Mississippi & - & - & - & YES \\
\hline Missouri & 2001 & - & -9 & $\mathrm{NO}$ \\
\hline Montana & - & 1989 & - & YES \\
\hline Nebraska & 2002 & 1989 & - & $\mathrm{NO}$ \\
\hline Nevada & -10 & 1987 & 1999 & $\mathrm{NO}$ \\
\hline New Hampshire & 2004 & - & - & $\mathrm{NO}$ \\
\hline New Jersey & 1999 & $\begin{array}{c}1991, \\
\text { repealed } 1999\end{array}$ & - & $\mathrm{NO}$ \\
\hline New Mexico & - & 1992 & - & YES \\
\hline New York & - & - & - & $\mathrm{NO}$ \\
\hline North Carolina & - & 1995 & - & $\mathrm{NO}$ \\
\hline North Dakota & - & 1991 & - & YES \\
\hline Ohio & 1999 & - & 一 & $\begin{array}{c}\text { NO, } \\
\text { YES beginning } 2003 \\
\end{array}$ \\
\hline Oklahoma & - & - & $2004^{11}$ & $\begin{array}{c}\mathrm{NO}, \\
\text { YES beginning } 1994\end{array}$ \\
\hline Oregon & - & 1990 & - & YES \\
\hline Pennsylvania & - & - & - & $\mathrm{NO}$ \\
\hline Rhode Island & 1999 & - & 1999 & $\mathrm{NO}$ \\
\hline South Carolina & - & 1987 & - & YES \\
\hline South Dakota & 1983 & - & - & $\mathrm{NO}$ \\
\hline Tennessee & - & 1994 & - & $\mathrm{NO}$ \\
\hline Texas & - & - & - & $\mathrm{NO}$ \\
\hline Utah & $2004^{12}$ & 1998 & 2004 & $\begin{array}{c}\text { YES, } \\
\text { NO beginning } 2004^{13}\end{array}$ \\
\hline Vermont & - & - & - & $\mathrm{NO}$ \\
\hline Virginia & 2000 & 2000 & - & YES \\
\hline Washington & $-{ }^{14}$ & - & - & $\mathrm{NO}$ \\
\hline
\end{tabular}

${ }^{9}$ See supra note

${ }^{10}$ See supra note _ _ and accompanying text.

${ }^{11}$ Oklahoma's statute limits settlors to a single asset protection trust and caps the permissible initial funding at $\$ 1$ million.

${ }^{12}$ Utah's statute, which is unclear, appears to establish a 1,000 year perpetuities period effective December 31, 2003. Given the length of this period, we treat Utah as having abolished the Rule.

${ }^{13}$ Only trusts that “first became” Utah trusts “on or after January 1, 2004” qualify for exemption from the income tax.

${ }^{14}$ Washington extended its perpetuities period to 150 years effective January 1, 2002. Because 150 years is not significantly longer than is possible through the use of a saving clause, we do not count Washington as having abolished the Rule. 


\begin{tabular}{|c|c|c|c|c|}
\hline State & $\begin{array}{c}\text { RAP } \\
\text { Abolished }^{2} \\
\end{array}$ & USRAP & $\begin{array}{c}\text { Self-Settled } \\
\text { Asset Protection } \\
\text { Trust (APT) } \\
\end{array}$ & $\begin{array}{c}\text { Fiduciary Income } \\
\text { Tax (FIT) }{ }^{3}\end{array}$ \\
\hline West Virginia & - & 1992 & - & NO \\
\hline Wisconsin & $1969^{15}$ & - & - & $\begin{array}{c}\text { YES, } \\
\text { NO after } 1999\end{array}$ \\
\hline Wyoming & $2003^{16}$ & - & - & $\mathrm{NO}$ \\
\hline
\end{tabular}

${ }^{15}$ See supra note

${ }^{16}$ Wyoming conditions the nonapplicability of the Rule on a provision in the trust instrument providing for the termination of the trust not later than 1,000 years after its creation. Given the length of this period, we treat Wyoming as having abolished the Rule. 


\section{APPENDiX A: EXTENDED TREATMENT OF DATA Limitations}

Exclusion of nonreporting trustees. Because our dataset includes only trust assets held by federally-reporting institutional trustees, our study does not include the entire universe of trust funds. Further, because inter vivos trusts are not publicly-recorded, there is no reliable data on the proportion of trust assets held by institutional trustees as compared to individuals. ${ }^{17}$ There are, however, good reasons to suppose that our dataset captures the trust funds most likely to be sensitive to the interaction of perpetuities and tax laws.

First, as discussed earlier, in order to ensure the desired choice of law, out-of-state settlors are all but required to choose a trustee located in the state whose law the settlor wants to govern the trust. ${ }^{18}$ Thus, unless the settlor knows someone who lives in the chosen state and is willing to name that person as trustee, the settlor has little choice but to choose a bank or other corporate fiduciary. Second, because a transfer-tax-exempt perpetual trust is designed to last in perpetuity, choosing an institutional trustee avoids the difficult problem of providing for trustee succession after everyone known to the settlor is dead. Third, anecdotal evidence suggests that the use of professional trustees has become more common, particularly for larger and more sophisticated trusts. ${ }^{19}$

To the extent that our data may not include some trusts assets that have moved to take advantage of the abolition of the RAP, their omission biases our results down, causing us to understate the magnitude of the phenomenon.

Inclusion of charitable trusts. Although charitable trust funds held by institutional fiduciaries are included in the data, we do not believe that their inclusion biases our results upward.

As a theoretical matter, the distribution of charitable trust funds across states should not be affected by changes in state perpetuities, state tax, or federal tax law. Charitable trusts are privileged with an exemption from the RAP and from state and federal taxation. Thus neither perpetuities nor tax law supplies a reason to settle a charitable trust out of state.

As an econometric matter, the differences in state trust assets caused by the inclusion of charitable trusts should be removed by state fixed effects, year dummies, and state-specific time trends. If not, the inclusion of charitable trusts at worst creates some noise, which would decrease our coefficient estimates and thus would cause us to understate the magnitude of the phenomenon.

\footnotetext{
${ }^{17}$ See Sitkoff, Agency Cost, supra note _, at 633 n. 57.

${ }^{18}$ See text accompanying supra notes

${ }^{19}$ See Langbein, Contractarian, supra note _ , at 638-40; Gregory S. Alexander, A Cognitive Theory of Fiduciary Relationships, 85 CoRNELL L. Rev. 767, 775 (2000); see also Barbara R. Hauser, Appreciating Corporate Trustees, TR. \& EsT., Aug. 2005, at 52 (noting an increased willingness in the last ten years to recommend use of a corporate trustee).
} 
Banking reform and charter jurisdiction. In the main text we address the concern that bank mergers or consolidations could bias our results. A related concern is that nationally-chartered institutions, which are regulated by the OCC and include some rather large entities (such as the Wells Fargo banks and the Citicorp banks), may report all of their assets in only one state. To the extent that this is true, however, the reporting location tends to be in large financial centers such as New York rather than in the small states that were the first to abolish the RAP. Thus, if there is bias, once again it would tend to cut against a significant positive finding. Further, on an anecdotal level, at least several nationally-chartered institutions maintain separately reporting offices. For example, Wells Fargo has independently-chartered and hence separately-reporting entities in Delaware, South Dakota, and Alaska; Citibank has separately-reporting entities in South Dakota and Delaware; and Bank of America has an independently-chartered and separately-reporting Delaware trust office. ${ }^{20}$

${ }^{20}$ See http://www2.fdic.gov/structur/trust/search.asp to find institutions, date of charter, chartering institution, and state. Maintaining several separately-charted institutions is evidently a common practice. See Jonathan Epstein, U.S. Trust Wants to Set Up in Del., NEws J., Juan. 27, 2000, at 7B; Jonathan D. Epstein, Financial “Climate” Attracts SunTrust, Tiedemann Trust, NEws J., Nov. 4, 1999, at 7B. 


\section{Appendix B: Trust Assets Per Person}

Appendix Table 1 considers trust assets per person as the dependent variable. This variable is relevant for several reasons. First, by denominating trust assets by person, we overweight the influence of large transfers to small states (e.g., Delaware and South Dakota), and these states may be the most responsive to state competition. Second, this variable divides trust assets by population, a factor likely to influence the amount of trust assets in a state. Our findings (except for the USRAP coefficient) are quite similar to those of Tables 1, 2, and 3. 
Appendix TABle 1: Reported State Trust Assets Per Person (In Thousands)

\begin{tabular}{|c|c|c|c|c|c|c|c|c|}
\hline Variable & Model 1 & Model 2 & Model 3 & Model 4 & Model 5 & Model 6 & Model 7 & Model 8 \\
\hline $\begin{array}{l}\text { Abolish RAP } \\
\text { Abolish*NoFIT }\end{array}$ & $\begin{array}{r}2.60 * * \\
(.72)\end{array}$ & $\begin{array}{r}1.62 * * \\
(.52)\end{array}$ & $\begin{array}{r}1.58 * * \\
(.54)\end{array}$ & $\begin{array}{r}.68 * \\
(.31)\end{array}$ & $\begin{array}{r}.42 \\
(.33)\end{array}$ & $\begin{array}{c}-.04 \\
(.31) \\
3.28 * * \\
(.74)\end{array}$ & & \\
\hline $\begin{array}{l}\text { Year Abolish } \\
\text { Year Before Abolition }\end{array}$ & & &.$- .35(.60)$ & & & & & \\
\hline $\begin{array}{l}\text { Year Betore Adolltion } \\
\text { Two Years Before } \\
\text { Abolition }\end{array}$ & & & $\begin{array}{l}-.14 \\
-.16 \\
(1.04)\end{array}$ & & & & & \\
\hline Years Abolished & & & & & & & $\begin{array}{l}.46^{* *} \\
(.25)\end{array}$ & $\begin{array}{r}.067 \\
(.078)\end{array}$ \\
\hline Years Abolished & & & & & & & $-.021 *$ & $-.018 * *$ \\
\hline Squared & & & & & & & (.010) & (.007) \\
\hline $\begin{array}{l}\text { Years Abolished } \\
\text { *NoFIT }\end{array}$ & & & & & & & & $\begin{array}{r}1.19 * * \\
(.26)\end{array}$ \\
\hline $\begin{array}{l}\text { Years Abolished } \\
\text { Squared*NoFIT }\end{array}$ & & & & & & & & $\begin{aligned}-.023^{+} \\
(.013)\end{aligned}$ \\
\hline APTs & & $\begin{array}{l}6.00 * * \\
(2.08)\end{array}$ & $\begin{array}{r}6.10^{* *} \\
(2.11)\end{array}$ & $\begin{array}{l}.68 \\
(1.28)\end{array}$ & & $\begin{array}{l}4.93 * \\
\quad(2.05)\end{array}$ & $\begin{array}{l}5.91^{* *} \\
(2.13)\end{array}$ & $\begin{array}{l}3.72^{+} \\
(1.97)\end{array}$ \\
\hline USRAP & & $\begin{array}{l}-.67^{*} \\
\quad(.29)\end{array}$ & $\begin{array}{l}-.64 * \\
(.29)\end{array}$ & $\begin{array}{c}.096 \\
(.23)\end{array}$ & ${ }^{.17}(.22)$ & $\begin{array}{c}-.47 \\
(.29)\end{array}$ & $\begin{array}{c}-.57^{8} \\
(.30)\end{array}$ & $\begin{array}{c}-.45 \\
(.29)\end{array}$ \\
\hline NoFIT & & $\begin{array}{l}.066 \\
(.35)\end{array}$ & .06 (.35) & $\begin{array}{r}-.093 \\
(.22)\end{array}$ & $\begin{array}{r}-.17 \\
(.24)\end{array}$ & $\begin{array}{r}-1.08 * \\
(.55)\end{array}$ & $\begin{array}{r}.093 \\
(.37)\end{array}$ & $\begin{aligned}-.028 \\
(.36)\end{aligned}$ \\
\hline Income per Capita/1000 & & $\begin{array}{r}.042(.061) \\
\end{array}$ & $\begin{array}{r}.048 \quad(.69) \\
\end{array}$ & $\begin{array}{r}-.077 \\
\quad(.084) \\
\end{array}$ & $\begin{array}{r}-.27 \\
(.51) \\
\end{array}$ & $\begin{array}{r}.047 \\
(.067) \\
\end{array}$ & $\begin{array}{c}-.058 \\
(.062) \\
\end{array}$ & $\begin{array}{l}-.011 \\
(.061) \\
\end{array}$ \\
\hline $\begin{array}{l}\text { Test Abolish, APT, } \\
\text { *NoFIT }\end{array}$ & & .0003 & .0004 & .1243 & & .0054 & & \\
\hline Test $\mathrm{Yr}, \mathrm{Yr}^{2}, *$ NoFIT & & & & & & & .0117 & $>.0001$ \\
\hline R-Square & .7713 & .7894 & .7906 & .9204 & .5725 & .7953 & .7988 & .8051 \\
\hline $\begin{array}{l}\text { State-Specific Time } \\
\text { Trends }\end{array}$ & No & No & No & Yes & No & No & No & No \\
\hline $\begin{array}{l}\text { Excluding RI, MA, DE, } \\
\text { and AK }\end{array}$ & No & No & No & No & Yes & No & No & No \\
\hline
\end{tabular}

